STATE OF ILLINOIS

DEPARTMENT OF REGISTRATION AND EDUCATION

DIVISION OF THE

NATURAL HISTORY SURVEY

STEPHEN A. FORBES, Chief

Vol. XIII. BULLETIN Article XVI.

\title{
AN ECOLOGICAL SURVEY OF THE PRAIRIE VEGETATION OF ILLINOIS
}

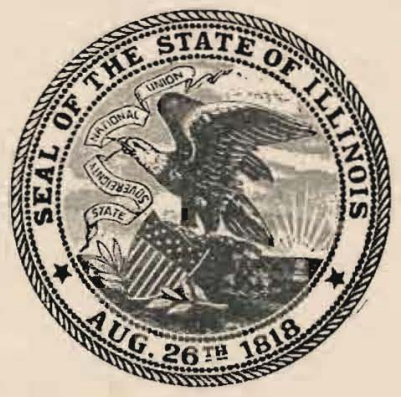

PRINTED BY AUTHORITY OF THE STATE OF ILLINOIS

URBANA, ILLINOIS

August, 1921 


\section{ERRATA}

Page 97, line 17, for first larval read pupal.

Page 112, in legend, for jonessi read jonesii.

Page 114, in legend', for or read of.

Page 125, line 4, for Bonosa read Bonasa.

Page 131, in legend, for hirundinaceus read hirudinaceus.

Page 138, last line, for coccoon read cocoon.

Plate XII, explanation page, next to last line, for acrivora read aerivora.

Plate XIII, explanation page, next to last line, for White-grubs read White-grub.

Page 293, Figure $5 a$ was reversed in printing, and the two items of the legend should change places.

Page 515, second table, for Pelocoris femorata read Pelocoris femoratus. 
Article XVI.-An Ecological Survey of the Prairie Vegetation of llinois.* By Homer C. Sampson.

\section{INTRODUCTION $\dagger$}

The purpose of this survey was to determine as far as possible the composition and ecological relation of the prairie vegetation of Illinois. The prairie area of this state is an eastern arm of the prairie region proper which forms a distinct formation between the grass-lands of the Great Plains on the west and the deciduons hardwood forest on the east. While the origin of this prairie dates back to the changes in climate following the uplift of the Rocky Mountains and subsequent changes during and following the glacial period, the factors limiting its present distribution are to be found in the present climatic and edaphic conditions together with the biotic factors which affect succession from prairie to forest associations.

The occurrence of all the great prairie regions of the world in temperate climates indicates that temperature plays a rôle, either directly or indirectly, in determining the general boundaries of distribution of the prairies. For the prairie under consideration, Transeau's map (26), comparing the ratios of rainfall to evaporation from a free water surface in the three great vegetational areas noted above, shows rather clearly that definite ratios of these two important climatic factors, with which temperature is indirectly involved, coincide closely with the present limits of distribution. The western boundary of the prairie is marked by a rainfall equal to about 60 per cent. of the evaporation from a free water surface, while on the eastern boundary of the prairie the ratio of rainfall to evaporation is about 80 per cent. Similarly the rainfall-evaporation ratios marking the boundaries of the Great Plains are 20 and 60 per cent., while those of the eastern forest range from 80 to 130 per cent. The prairie therefore lies in a region in which the ratio of rainfall to evaporation ranges from 60 to 80 per cent. (See map on next page.)

The presence of local areas of forest together with man's ability to carry on silviculture throughout the greater part of this range is sufficient evidence that the occurrence of prairie vegetation is not limited by climate alone. Edaphic factors and the difficulty with which a forest vegetation invades and succeeds that of the prairie must also be taken into account. As the complex of climatic factors approaches the limiting conditions for forest development, the weight of the edaphic factors be-

* Papers from the Department of Botany, Ohio State University. No. 126.

t For non-technical summary, see page 569 . 
comes more and more evident and may tip the balance either in favor of forest or of prairie. Similar conditions exist between prairie and plains vegetation on the western edge of the prairie. But as we approach the center of the prairie region edaphic factors become less prominent, and it is here that we find prairie on the greatest number of edaphic habitats.

Transeau $(25,26)$ was the first to point out the characteristics of the centers of distribution of the vegetation of bogs and forests of North

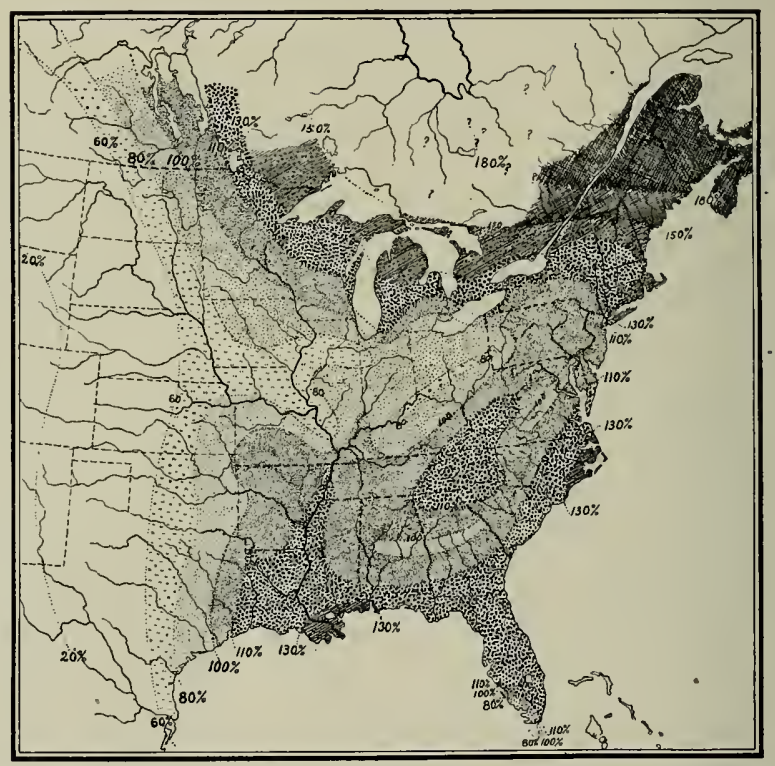

Map showing ratio of rainfall to evaporation expressed in percentages. (After Transeau.)

America and to call attention to the meaning and use of the term "center of distribution". As he used it the term does not imply that the plants have necessarily spread from the present centers, but that the complex of climatic factors most favorable to the development of the type of vegetation characteristic of each center is localized there, and that as we depart from such centers we find conditions more and more unfavorable and resulting in the elimination of such species as are most rigidly 
dependent upon climatic conditions. He also showed that the species comprising the vegetation of any center are more abundant, attain a greater size, and have a wider range of habitats within the limits of the center of distribution than elsewhere. These same conditions apply to the prairie. In addition to the climatic, edaphic, and biotic factors mentioned above, prairie fires are also important locally and have been variously emphasized from time to time.*

To sum up, climatic factors are important in determining the general boundaries of distribution of the prairie, while edaphic factors are important in determining the origin and character of the prairie associations within these boundaries. The edaphic factors become more and more prominent toward the edges of the prairie, as in eastern Illinois. When a prairie association is once established, biotic factors and prairie fires are important in checking invasion by forest vegetation.

The location of Illinois at the eastern boundary of the prairie makes it a region of considerably more than local ecological interest. Is a prairie state it has awakened interest since the time of the first settlers. several of whom have recorded brief but glowing descriptions of the early prairies. Of these older descriptions, one of the most important was written in $18, \%$ by Frederic Gerhard $(i)$, who greatly enriched his publication by appending a forest and prairie map of the state compiled by Dr. Frederick Brendel of Peoria. This map shows the relative distribution of prairie and forest at that time, and a reproduction of it by Barrows (1) is included in the present article (page 526).

Unfortmmately these pioneer writers, accustomed to life in a forested region, were generally unfamiliar with the plants of the prairie and failed to leave us an adequate account of the natural prairie flora. Furtherqnore, the importance of a knowledge of the relationship of plants to the environment in which they live was not recognized until a later date. Indeed the dynamic and genetic relationship of plant associations was not fully appreciated until Cowles $(t)$ pointed out its significance in $18,9 ?$. As a result of this belated appearance of modern ecological conceptions the earlier accounts of the prairie are notably lacking in a record of the different associations of prairie plants and of their composition and successional relationships. The published accounts deal chiefly with associations on the broken soil of slopes or with those along forest borders conspicuous for their great display of coarse herbs, and leave the erroneous impression that the original prairie flora was a mixture of a great variety of species. This impression, however, is offset by the occasional and significant reference to the prairie as a "sea of grasses" and hy the statement of C. IV. Short in 1845 that "Its leading feature is rather the unbounded profutsion with which a few species occur in certain localities than the mixed variety of different species occurring everywhere".

* For an historical résumé of the theories of the prairie see shimek (2t). "The Prairies." 


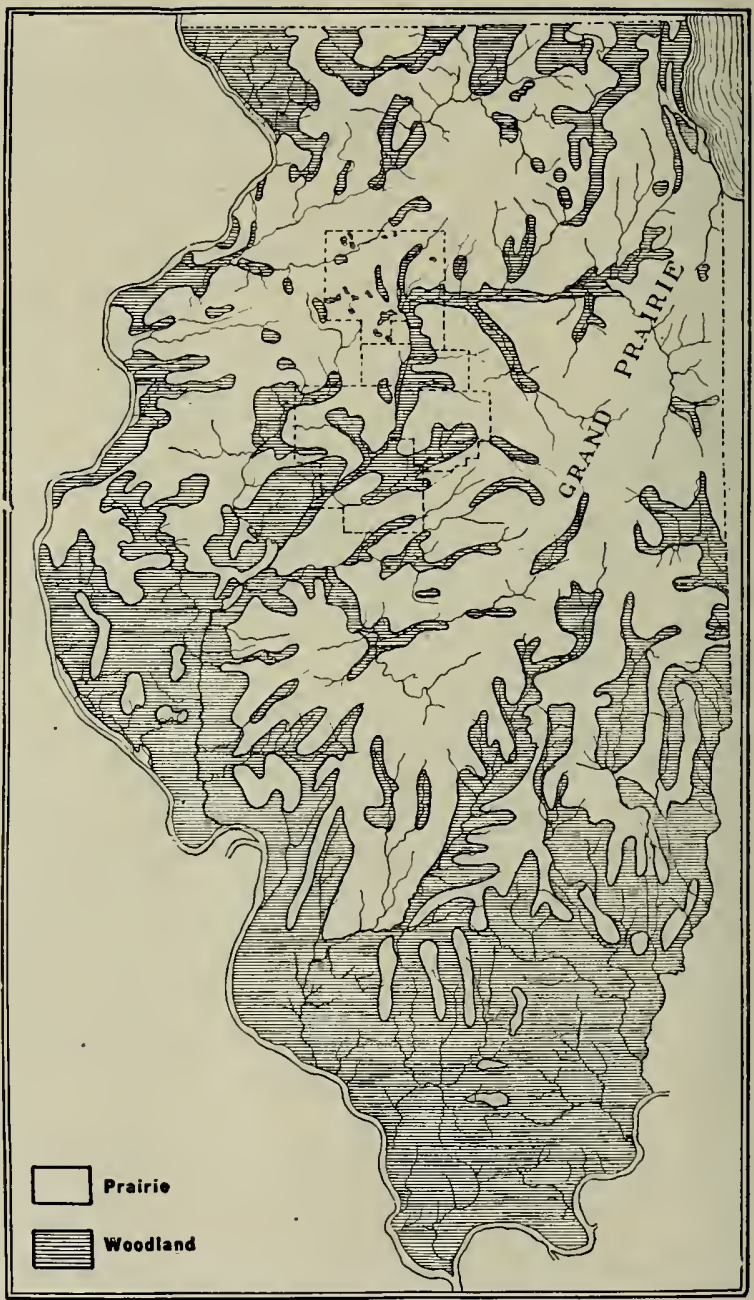

Orlginal Prairie and Forest Area in Illinois

(After Brendel and Barrows) 
Cowles $(4,5)$ has shown that the plant associations and their successions in a given region are correlated with its physiographic development. In order therefore to determine the original prairie associations the onty feasible point of attack lies in a detailed study of the relic associations still to be found in the various physiographic habitats of the state. The conditions in these relic associations where least disturbed by man approxinate closely the conditions which existed in the much more extensive association of only a little more than half a century ago. The order of succession of the associations is without doubt the same torlay as in the past, and the composition of the undisturbed associations fairly representative. Some of the swamp prairies and many of the sand prairies of the state have already been studied on this basis by Cowles (5), Sherff (23), Gleason (9, 10), Gates (6), and lestal $(2 \%, 28)$. The present investigation was also carried out on this basis with special reference to primitive conditions and an attempt to include practically all the prairie habitats of the state. The main contribution of this report is the attempt to determine and classify the associations of prairie vegetation in Illinois and point out the succes- . sions between them. The field work was entirely observational, but experimental data of other workers have been drawn upon wherever they appear to have a direct bearing upon the topic under discussion. Quantitative experimental data on the physiological factors underlying the problens of the prairie associations and their successions are too meager at present for a full discussion of the underiying causes. A more definite knowledge of both the ecological anatomy and physiology of many of the plants concerned will have to be obtained before some of the nore fundanental questions can be answered.

Most of the investigations were made during the summers of 1915 and 1916 with the cooperation of the Illinois State Laboratory of Natural History, through its director, Professor Stephen A. Forbes, and under the direction of Dr. H. C. Cowles and Dr. George D. Fuller, of the University of Chicago. This report also contains many data obtained previous to the above dates and from observations made in many sections of the state during the summers of 1918 and 1918. I am particularly indebted to Professor Forbes for his cooperation in the survey and for the aid he has given in the illustration of the report. I wish also to express many obligations to Dr. Fdgar N. Transeau, of the Ohin State University, who first introduced me to the problems of the prairie iii the summer of 1910 , and helped me with valuable data and criticisms during the preparation of this report. To Dr. A. E. Waller, of the Ohio State University, I am indebted for criticisms and suggestions on the final report.

\section{Location of Existing Virgin Prairies of the State}

The location of most of the prairies studied was obtained by means of circular letters of inquiry sent to each of the county surveyors of the 
state. Seventy-three of a possible 102 replies were received. The following tabulation by counties is taken directly from the letters received. It should be noted that these reports are not exhaustive, as no surveyor would be expected to have a complete list of all the undisturbed areas of his county. In some cases more definite statements are desirable, but the ones given are included with the hope that they may be of value to other workers in the field. Unfortunately, grazing was not suggesterl as a type of disturbance in the letters of inquiry, and some of the areas here reported have been pastured and are now generally blue-grass pastures. Where this fact is known it has been added by the writer. Asterisks refer to regions investigated in this survey.

Adans. Lowlands along the Mississippi River extending throngh three townships north of Quincy.

Bond. A few small tracts in addition to numerous roadsides.

*Bureau. Several thousand acres of sand and swamp prairie along Green River. Mostly pastured.

*Carroll. Several thousand acres of sand prairie and flood-plain prairie south of Savanna. Most of the sand prairie and some of the flood-plain prairie has been pastured.

*Cook. About 5,000 acres on the old lake bed of Lake Chicago and a few small tracts on the Valparaiso moraine. There are 2,000 acres in the vicinity of Ashburn within the city limits of Chicago.

*Crazuford. One hundred and sixty acres two and one-lalf miles northwest of Porterville. Pastured.

De Kalb. About four acres near Maple Park. R. E. Wagner.

Dupage. Small areas along east branch of Dupage River between Swift and Lisle.

*Effingham. A few small tracts and roadsides. An 80-acre tract of Andropogon prairie on the farm of David Woods, 9 miles southwest of Dietrich, was reported to the writer in 1918 . Forty acres of this tract reported plowed in $191 \%$.

Fulton. Lowlands along the Illinois River.

*Grundy. "Hay swamps" north of Coal City; 220 acres 5 miles west of Morris along the Illinois River. Mostly flood-plain; some moraine and mostly pastured.

Hancock. Flood-plain along Mississippi River south of Warsaw.

*Henry. Sand and swamp land in northern part of county. Mostly pastured.

* Jasper. Forty acres southwest of Gila and 320 acres 3 miles east of West Liberty. Pastured. Burke's prairie of 2 acres two miles southwest of Wheeler. Virgin. A small area northwest of Wheeler now under cultivation.

*Jo Daviess. Some prairie in north and southwest part. Pastured. Madison. Wet prairie in Shonteau township. 
* Marshall. Saratoga Lake region one mile north of Camp Grove. Another small area 6 miles east of Lacon. Mostly swamp, some upland prairie.

Mercer. Flood-plain along the Mississippi River.

Ogle. Small tract one mile east of Polo. W. E. Eikenberry.

Pcoria. Lowlands along the Illinois River.

Randolph. Flood-plain along Mississippi and Kaskaskia rivers.

*Richland. Fox Prairie, 5 miles west of Olney. Cemetery at Noble.

Rock Island. Flood-plain along Mississippi River.

Washington. Flood-plain along Kaskaskia River.

Whitc. Small tracts in Enfield and Hawthorn townships.

Whiteside. Prairie between Albany and Erie.

Winnebago. Small tracts along Rock River.

All of the above counties and the remaining counties with the exception of those in the southernmost part of the state were reported to have patches of virgin prairie along railway rights-of-way, old line-fences, and roadways. Owing to a difference in farning methods these latter relics are somewhat more abundant in the southern half of the state than elsewhere. Numerous relics along most of the principal railways of the state and along hundreds of old line-fences were seen during the survey.

This brief summary of present conditions shows that there are still several thousand acres of virgin prairie in the state which have been so little disturbed by man that they are of considerable value for ecological studies. The data also show that the greater area of these relic tracts are on flood-plains, swampy regions, and sand. Outside of the sand prairie the upland prairies are limited to small tracts, fence-rows, and railway rights-of-way, the latter of which were considered only after the survey had advanced sufficiently to indicate their limitations.

\section{Origin of the Prairie Habitats}

The various plant habitats of the state are correlated with its recent geological history. The accompanying glacial and soil map after Leverett (18) and Hopkins (15) shows that nearly all of the state has been glaciated. The glaciers left the state with a gently rolling topography. The depressions, resulting from the formation of moraines across preglacial valleys and the unequal deposition of the glacial drift, became postglacial lakes and sloughs which were slowly drained. In general the moraines became forested, but many of the lakes and sloughs through gradual filling and draining became prairies, a process which was far from complete when the farmer entered the state and established artificial drainage systems. The extensive areas and long duration of the wilderness of sloughs and swamps in the Wisconsin glaciation is best attested today by the depth and extent of the rich humus soil that accumulated in them. Their estimated dimensions are not lessened by the stories of the early settlers who swam their horses across them in early 


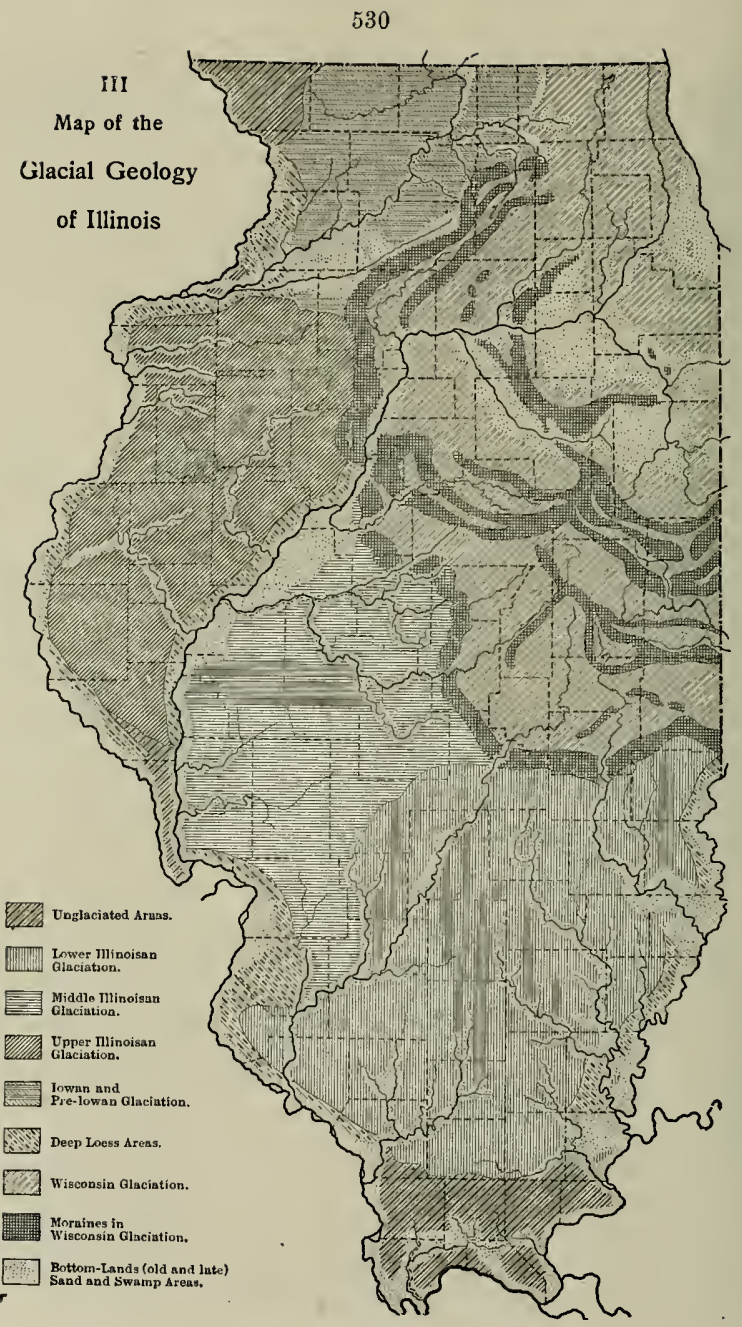


spring or skated for many miles across country in winter with but short walks between the swamps. Artificial drainage has not only reduced the swamps, but it has also caused a general lowering of the watertable, so that wells in this region must now be dug $5-10$ feet deeper than formerly. A few of these undrained morainal depressions surrounded by definite zones of native vegetation remain today, but most of them have been disturbed by grazing and mowing. The swamp prairies of the Chicago plain with their intervening lines of beaches may be included in this group.

Postglacial drainage at first favorable for prairie formation through the drainage of swamps ultimately became destructive through erosion of the soil in the development of the natural drainage systems. The invading heads of the ravines destroying the prairie turf were usually accompanied by the development of a forest vegetation. This fact is strikingly illustrated in Brendel's map, which shows a fringe of forest along all the principal water courses. These belts of forest are much narrower and the intervening prairies much larger on the youthful topography of the Wisconsin glaciation than on the older Illinoisan glaciation. This condition is a result partly of the difference in age of the drainage systems of the two regions and also of the greater amount of forest encroachment on the pre-erosion areas of the prairie in the southern Illinoisan glaciation. Flood-plain formation has resulted in both forest and prairie; the prairies arising from the lagoons and swampy regions have much in common with those arising from morainal depressions. Outwash from the Wisconsin glaciers gave rise to enormous sand areas and sand dunes in the northern half of the state, some of which were forested, the remainder being covered with a prairie vegetation and plants of the Great Plains. Rock outcrops and eroding clay bluffs were generally forested, but the slopes of lower gradient were frequently covered with a xerophytic prairie flora. Local areas of this type are still to be found in the vicinity of forest borders, though many of them must be regarded as secondary successions following deforestation.

In addition to the prairies arising from postglacial lakes and subsequent erosion, there is some evidence that the sand prairies and some of the upland prairie region of the state date back to an arid postglacial period during which there was an eastward extension of the prairie and plains flora. The conifer zone following the retreat of the glacier is thought to have been succeeded immediately by a xerophytic prairie flora extending as far eastward as Ohio. Subsequent increase in humidity in the Mississippi valley was then followed by a westward migration of a more mesophytic prairie flora and the deciduous forest of the east which have their present tension zone in Illinois. As evidence of this view Gleason ( 8 ) calls attention to the presence of scattered colonies of prairie species beyond the eastern limit of the present prairie province and to the isolated occurrence of such western plants as Cristatella 
Jamesii, Lesquerella, argentea, and Opuntia fragilis on the sand dunes of Illinois many miles from their nearest reported station in the west.

This brief summary of the prairie habitats of the state emphasizes the fact that the chief prairie region reached its greatest development on postglacial pre-erosion topography. The associations of prairie plants found in these habitats may be placed in two distinct groups: the hydrarch successions found on flood-plains, in morainal depressions, and on the old lake bed of Lake Chicago ; and the xerarch successions found on sand and xerophytic upland glacial soils.

\section{Succession of Prairie Plant Associations}

\section{THE HYDRARCH SUCCESSIONS}

\section{The Succession (a) on the Rizer Flood-plains}

The largest and least disturbed example of this type of prairie studied is located on the flood-plain of the Mississippi River south of Savanna. The exact area of this prairie was not determined, but it is known to include several thousand acres. The associations of prairie plants found on this flood-plain are usually distinct and readily differentiated. The list of associations found and their successional relations are represented diagramatically in Figure 1. See also Plates XLVIIILIII for illustrations of the individual associations, and pages $558-56 \mathrm{~s}$ for a list of representative species.

The associations in the diagram are given in order from swamp to prairie. On these Savanna prairies the plants representing the various associations usually occupy from 85 to 95 per cent. of the area of the association which they represent and are in every case the dominant plants of their respective associations. The areas of the individual associations vary from a few square rods to tens of acres. Where the slope gradient is steep they occur as narrow strips of only a few feet in width and some of them may be eliminated entirely. One Panicum virgatum association was found occupying nearly a hundred acres (Plate LII), and similar areas of Spartina Michauxiana are not infrequent. Andropogon furcatus is the dominant grass of the drier portions of the flood-plain, but owing to the fact that habitats which have reached this stage of development are suitable for agriculture very few such areas remain undisturbed.

Some of this prairie is now being grazed and is losing its natural aspect. Hundreds of acres, however, are disturbed only by late autumn mowing and occasional fires, while occasional local areas may be found that are seldom disturbed by man. It is in these least disturbed tracts where the dead grass remains from year to year that the dominant plants maintain their purest stand. The secondary species become insignificant, being represented only as scattered individuals here and there throughout the association. It is in such situations also that the transition zones between the various associations are most clearly defined and readily recognized. 


\section{Andropogon furcatus}

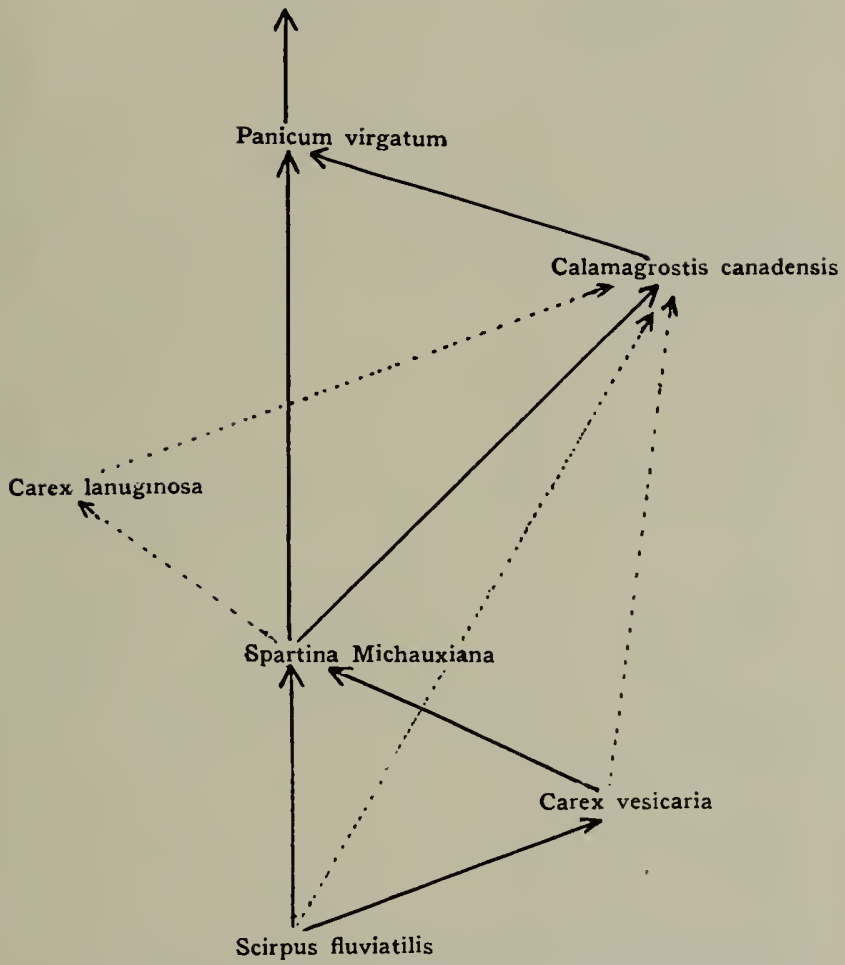

Fig. 1. Diagram showing the successions of the plant associations from swamp to prairie on the flood-plain of the Mississippi River at Savanna, Illinois. The dotted lines, represent local exceptions of rare occurrence, See Plates XLVIII-LIIF.

The data obtained from the surveyors' reports show that the greater amount of undisturbed flood-plain prairie occurs along the Mississippi River. Similar areas, however, occur along the Illinois and smaller rivers. The driest of these flood-plain prairies found, are along the Desplaines River near Riverside, in Cook county. These areas have been 
modified by pasturing and are dominated by Andropogon furcatus or its ecological equivalents.

The data in Figure 2 were obtained from a 220 -acre field along the Illinois River five miles west of Morris, in Grundy county. The trend of associations on the unpastured portion are practically identical with those along the Mississippi.

It is important to note that the data in Figure 2 also show the effect of grazing upon the natural prairie flora. Practically every one of the dominant species occurring under natural conditions is replaced by some other species. Scirpus fuviatilis is replaced by Typha latifolia; Spartina Michauriana and Calamagrostis canadensis, partly by Carex and Juncus but mostly by Agrostis alba; Panicum virgatum, partly by
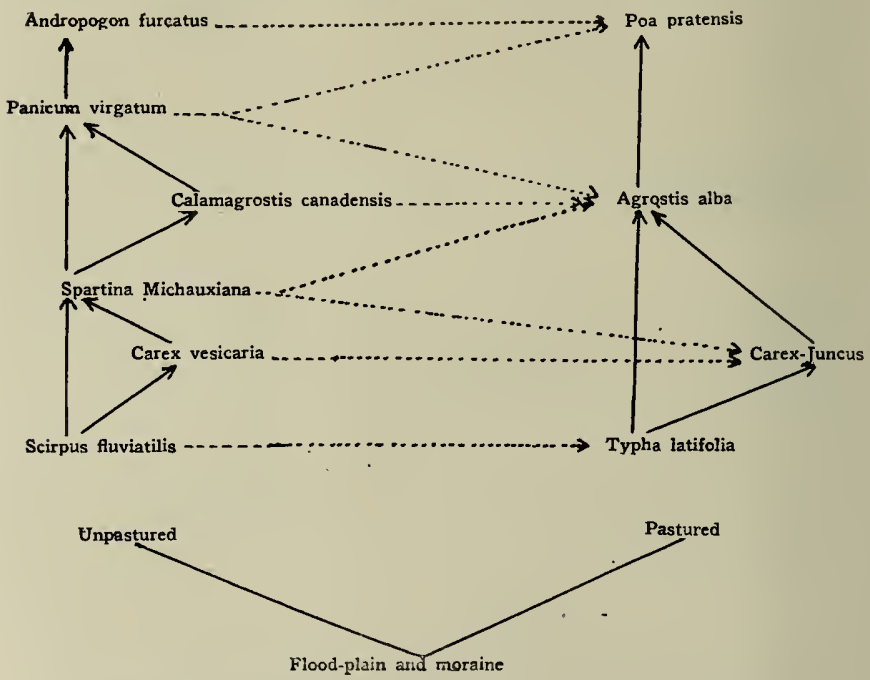

Fic. 2. Diagram showing the successions of the plant associations on pastured and unpastured areas on the flood-plain of the Illinois River in Grundy county. The dotted lines indicate the successions brought about by grazing.

Agrostis alba and partly by Poa pratensis; and Andropogon furcatus, entirely by $P$ oa pratensis. Not only are these primary species destroyed by grazing, but practically all of the secondary species are likewise eliminated. It may readily be seen that areas not subjected to intense grazing or areas that had been pastured in the past and then allowed 
to revert to natural conditions would exhibit a mixture of associations of native and cultivated grasses impossible to decipher on an ecological basis unless ecological equivalents are recognized and appreciated. The above data are important in suggesting an explanation of the conditions existing on the Chicago plain, to be discussed later.

According to the county soil reports (3) the surface soils of these flood-plain areas consist in the main of brown silt loam and sandy silt loam derived from materials washed frow the upland and deposited at periods of overflow. Usually there is present a considerable amount of sand. The subsoil as a rule is sandy silt loam, sand, or clay. In some of the swamps peat is abundant. Enormous areas of peat occur on the wide flood-plains of the Rock and Green rivers in Bureau. Henry, Lee, Whiteside, and Rock Island counties. The peat beds occur in depressions between the sand hills and in morainal depressions.

With the exception of peat all of these soils are rich in the minerals required by plants, and their plant associations are similar. Peat, on the other hand, is exceptionally rich in organic material and poor in potassium, but its plant associations are dominated by the same species that dominate wet areas on other types of soil. Calamagrostis canadensis is particularly prominent on wet peat. The height of the water-table and not the chemistry of the soil is the limiting factor determining the order of associations.

Some progress toward an explanation of the order of occurrence of the associations in the bydrarch succession has been made, but the data at present are little more than suggestive. Miss Hayden $(13,14)$ found that parenchyma and aerenchyma are more prominent in roots and rhizomes of swamp plants than of upland plants on the prairie of central Iowa, and that the leaves of upland plants have thinner epidermal walls, a greater amount of palisade-tissue and more compact mesophyll, and are more frequently hairy than leaves of plants on the lowlands. IVe are greatly in need of more ecological anatomy of this type which should be extended to include the dominant species of the prairie associations. It should also be checked by experiments similar to those of Cannon and Free (2) to determine the effectiveness of aerenchyma in supplying oxygen to roots in soils of low oxygen content. It should further be checked by actual measurements of transpiration rates to determine the comparative effectiveness of the various modifications of leaf structure. Transeau in some unpublished work has found that a heavy cuticle on leaves does not necessarily mean that they have a lower transpiration rate than leaves with thin cuticle. Sayre (21) found that hairs on mullein leaves do not retard transpiration under ordinary intensities of wind and light, and that eighty per cent. of the transpiration from these leaves is stomatal transpiration. Some of the modifications in leaf structure, therefore, affect only the twenty per cent. of transpiration directly from the epidermal cells, and there is great danger of overemphasizing their importance in the absence of experimental data. 


\section{The Hydrarch Succession (b) on the Old Lake Bed of Lake Chicago}

The geological history of this region has been described in detail by Leverett (1\%) and Salisbury and Alden (20). The following sunmary is given to bring out more clearly the relation of the vegetation to the present physiography. During the retreat of the Wisconsin ice sheet, a temporary balance between the melting back of the glacial front and its forward movement resulted in the formation of the Valparaiso moraine. With further recession of the glacier this moraine served as a dam which hemmed in the water from the melting ice, forming a lake known as Lake Chicago. The surface of this lake was at one time 60 feet above the present level of Lake Michigan. An outlet through the Desplaines River gradually lowered the level of the lake until the glacier receded far enough to open an outlet to the north which resulted in the withdrawal of the water from the Chicago plain. Three old beach lines, sixty, forty, and twenty feet above the present level of Lake Michigan, show that the outlet to the north was interfered with a second and third time, and that a lake again occupied the area in question. With the final retreat of the glacier and subsequent drainage through the St. Lawrence System the water was gradually drained from the region between the Valparaiso moraine and the present beach of Lake Michigan. The area thus exposed was a flat, level plain, poorly drained, and abounding in lakes and swamps which have been gradually filling with vegetation.

The old beaches and sand-dunes areas are forested, but the remainder is largely prairie or swamp land. Much of the present undisturbed prairie is considered too wet for agricultural purposes except in dry seasons. In some of the drier portions, however, cultivated plants ecologically equivalent to Panicum virgatum and red top could be grown. Roadways and ditches have recently been established along the main section lines, and in some cases city blocks have been laid out. This artificial drainage has reacted to some extent upon the natural vegetation, and it is undoubtedly a partial cause of some of the disturbances noted in the natural plant associations of this area.

The drainage ditches are marked by a line of cottonwoods and a few willows, mostly Salix anygdaloides, though in some places swamp grasses are found refilling the ditches. These trees are growing in the bottom of the ditches where the prairie turf has been completely destroyed.

This prairie is exceptionally rich in organic matter, peat sometimes occurring. The subsoil is mostly glacial till, forming poor subsoil drainage, but local areas of sand and rock also occur. Owing to the flat surface and the impervious clay subsoil, much of the surface soil is usually saturated during the wet spring months. Later in the season the water content under present conditions of drainage may drop below the wilting coefficient. Harvey (12) has shown that during the summer of 1911 the 
water content of this soil at a depth of $7.5 \mathrm{~cm}$. was below the wilting coefficient during most of the period from the first of July to the last of September, and at a depth of $25 \mathrm{~cm}$. the water content was but a little above the wilting coefficient for the same period. Plants growing throughout the season, therefore, must be able to maintain a suitable

\section{Poa pratensis}

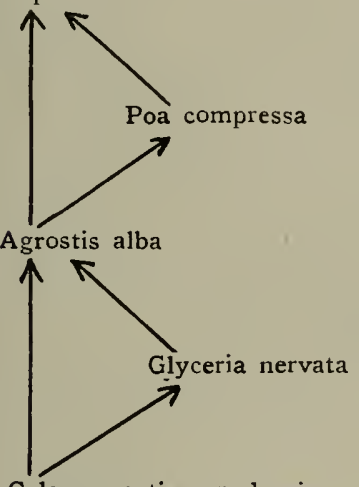

Calamagrostis canadensis

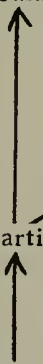

\section{Scirpus fluviatilis}

Fig. 3. Diagram showing the succession of the plant associations around a pond near Chicago Lawn on the old lake bed of Lake Chicago. Disturbance by man has made possible the occurrence, here, of associations dominated by Glyceria and cultivated grasses. see Plate LIV. water balance through the two opposite extremes of soil-water content. Since the roots of many prairie plants grow deeper than $25 \mathrm{~cm}$., we need more data on the wilting coefficient in relation to depth of root systems of the dominant plants in the different associations.

More than 4,000 acres of this prairie are included in this survey. Figure 3 , shows the trend of associations from a small pond near Chicago Lawn. The prominence of the cultivated grasses, Poa and Agrostis, in this locality is very probably the result of the suburban habit of "staking cows out to pasture", but, as will be shown later, other factors may also be important here.

In Figure 4 an attenipt is made to summarize the relations of the principal associations on the Chicago prairie including those of cultivated grasses. No attempt is made to include all the associations in the deeper swamps. These have been described in detail by Sherff (23) and Gates (6).

The data show that there is a far greater complexity of associations on this prairie than on those discussed above. In the first place the appearance of associations dominated by Agrostis alba and by the blue grasses, Poa pratensis and Poa compressa, represents a condition in this prairie not characteristic of the natural prairies of the state. There is no evidence in the older descriptions of the prairie that either of these species was present in the original prairies of the 


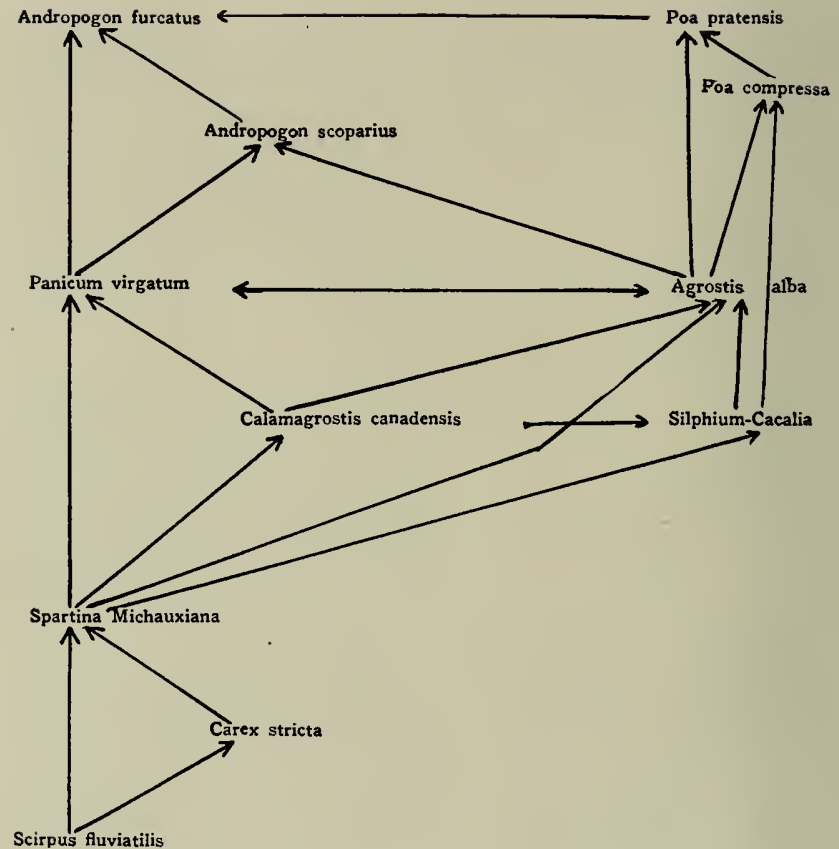

Frg. 4. Diagram showing the successions of the principal associations on the old lake-bed of Lake Chicago, including those of cultivated grasses. See Plates LI, LIV-LXIV.

state. Their presence today is the result of their introduction and use in cultivation. The blue grasses were apparently introduced from Europe. Waller (30) finds that the early settlers of Virginia and Kentucky looked upon Poa pratensis as a dangerous introduced weed and some of them prophesied that it would some day drive the farmers out of the country. A wealthy plantation owner, fearful lest the blue grass would ruin his pastures, ordered his slaves to dig it out and burn it. The early settlers of Illinois say that blue grass came into the state following the destruction of the native grasses by cultivation and grazing. The prominence of these cultivated grasses on the Chicago prairie is, indicative of disturbance by man and raises the question as to how far this prairie may 
be considered representative of original conditions. The data in Figures 2 and 5 show that grazing results in the coming in of cultivated grasses. A knowledge of the amount of grazing this prairie suffered during the early development of Chicago is wanting. During the last forty years the grass has been cut annually in July. This is rather more detrimental to the late fall grasses than to the earlier grasses in that it destroys their vegetative growth shortly before time for fruiting and usually prevents them from seeding. In addition, fires started by trains contribute to the disturbance of the composition of associations which obtained under natural conditions of competition. Artificial drainage has lowered the water-table and extended the seasonal period during which the water content of the soil is below the wilting coefficient. During the slow readjustment of the associations of native species to the disturbing conditions other species have a chance to obtain a temporary foothold. These cultivated grasses are not able to invade the undisturbed native associations, and the period of their dominance in disturbed areas is dependent upon the continuation of the disturbances.

In the second place a number of coarse herbs become more conspicuous, notably Silphium laciniatum, Cacalia tubcrosa, and Liatris spicata, which usually follow Spartina and Calamagrostis and may be found in pure or mixed stands of various combinations now occupying the greater part of local areas. Apacynum cannabimum var. Iypericifolimm is also occasionally abundant at this stage. On the slightly drier prairies Silphium tercbinthinaccum and Eryngium yuccifolium are sometimes abundant.

Finally, the occurrence of a mixed association dominated largely by Andropogon scoparius and Sporobolus hetcrolepis following Agrostis alba and Panicum virgatum on the low prairies seems out of harmony with the xerophytic nature of these grasses. The same species also dominate a portion of the Calumet beach near Chicago Ridge where it has been deforested. In this latter situation these species are in a xerophytic habitat characteristic of them, but on the low prairie they appear in the hydrarch succession which is not characteristic of them. Isolated clumps and small patches of Andropogon furcatus occur with then. In my opinion the above factors explain the occurrence of cultivated grasses in these prairies and also account for the AndropogonSporobolus association in the hydrarch succession and for the notable abundance of coarse herbs. During the period of readjustment following disturbance, the speed of migration becomes an important factor which in turn depends upon the proximity of plants producing an abundance of readily dispersed seeds. Andropogon furcatus is not nearly as abundant on the hills and sand dunes near Chicago as are the other grasses. and the latter, therefore. have a chance to obtain the first foothold on drained and denuded areas. It appears that the composition of the associations on the Chicago prairie is scarcely more representative of the composition of the earlier natural associations than are those found on railway rights-of-way. 
On the other hand, if we disregard the blue grass and red top in any given area or choose areas in which they have not gained a foothold the order of succession of the associations of native grasses is readily seen. With the exception of the presence of Andropogon scoparius and Sporobolus heterolepis in some places this succession of associations does not differ materially from that of the flood-plain prairies already described.

Andropogon furcatus does not play a very important rôle on the Chicago prairie. Under natural conditions most of this prairie was too wet for Andropogon. As noted above, it is frequently found on the higher ground, and it is most abundant in the neighborhood of the artificial drainage ditches. One of the areas that shows clearly the succession from Panicum virgatum to Andropogon furcatus on this prairie is about one half mile southwest of Oak Ridge (Plate LIX). The fact that this particular prairie is separated from the Wabash railway by a small stream is probably significant. The conditions on this area are more like those in other parts of the state. Coarse herbs are present but they occur as scattered individuals of secondary importance. Red top and blue grasses are not abundant. Special attention should be called to the fact that owing to their much greater height the native grasses readily crowd out the cultivated grasses in regions undisturbed by man. Mowing checks but does not entirely prevent the encroachment of Andropogon furcatus in associations of Poa pratensis. This fact was obtained from observations on carefully mapped areas about one mile northwest of Ashburn just north of $8 \%$ th Street on some of the best drained portions of this prairie. While the observations on this particular area were limited to a period of only three years, a slight increase in the amount of Andropogon was evident. The data recorded in Figure 6 show still more conclusively that when man does not interfere too much, Andropogon furcatus will crowd out our cultivated grasses.

Portions of the Chicago prairic have been cultivated from one to a few years and then abandoned. In all cases so far observed these abandoned areas have reverted again to prairie. Agrostis alba is usually the first grass to get a foothold. Coarse herbs likewise get an early start. Then blue grass and Andropogon follow. The reversion to prairie is not entirely due to the absence of "seed trees". Seedlings of cottonwood frequently make a start, but owing to subsequent mowing and burning they are usually destroyed.

\section{The Hydrarch Succession (c) in Morainal Depressions}

The morainal depressions vary in size from the small ones found in terminal moraines to the much more extensive ones of the ground moraine. Many of these depressions were formerly post-glacial lakes which became partially drained by subsequent gradation. As would be expected, the greater area of these depressions today occurs in the less 
eroded Wisconsin glaciated region. The horizontal or geographical succession of associations in these depressions at present is important in showing the vertical or historical succession of associations during the gradual filling and draining of the sloughs since glacial times. Inch of the Andropogon furcatus prairic of the state originated in this way.

Mr. L. Wiles, of Dundas, Illinois, who plowed some of the virgin prairie in Vermilion county before artificial drainage was established, says that the only tillable soil between the rivers and sloughs was that covered by tall bluestem (Andropogon furcatus), and that usually the farmers were not able to plow quite all of the Andropogon prairie but had to leave a narrow strip of it surrounding other grasses bordering the sloughs in the depressions. In many places in the faming district these depressions have not yet been completely drained, and where grazing has not been too severe the successions of the native grasses are still evident. In some places, as in the depressions near Camp Grove and Lacon in Marshall county, all the associations up to and including Andropogon furcatus may be found, while in other depressions farming has destroyed the Andropogon, and sometimes Panicum, entirely. A summary of these associations made from observations of more than twenty morainal depressions is given in Figure 5 .

Vestal (28) has described the associations about a small depression on the Valparaiso moraine on the boundary line of Cook and Dupage counties. While this prairie has some indications of the influence of civilization, such as the presence of red top and blue grass previously mentioned for the Chicago prairies, it is of interest as a description of a more xerophytic type of prairie characteristic of clay soils in the vicinity of forests. The hydrarch series is somewhat similar to that already described for the Chicago prairie, including the abundance of cultivated grasses and herbs. On the most xerophytic areas of the upland Andropogon scoparius is dominant. Silphimm laciniatum occurs in patches as a local dominant. Several other coarse herbs are of frequent occurrence.

The effect of grazing shown in Figure 5 is the same as that already discussed in connection with the flood-plain prairies. The conversion of natural prairie grass-lands to blue grass and red top by pasturing has occurred throughout the entire state. This fact is of interest both to the plant ecologist and to the farmers. In the first place the natural prairie grasses of any habitat serve as an indicator of the kind of cultivated grasses most suitable for that habitat. This might be further extended to include all the agricultural crops of the region (Waller, 29, 31 ). In the second place it points clearly to the best method of obtaining permanent pastures. The data show that Kentucky blue grass is the dominant pasture grass of all the upland prairie region, and when once established it remains a permanent feature. On the other hand timothy and red top pastures are in general short-lived but have the advantage of establishing themselves more quickly. It is a well known fact that the blue-grass pasture sod can not be obtained the first season after seeding. This difficulty, however, is readily overcome by seeding 

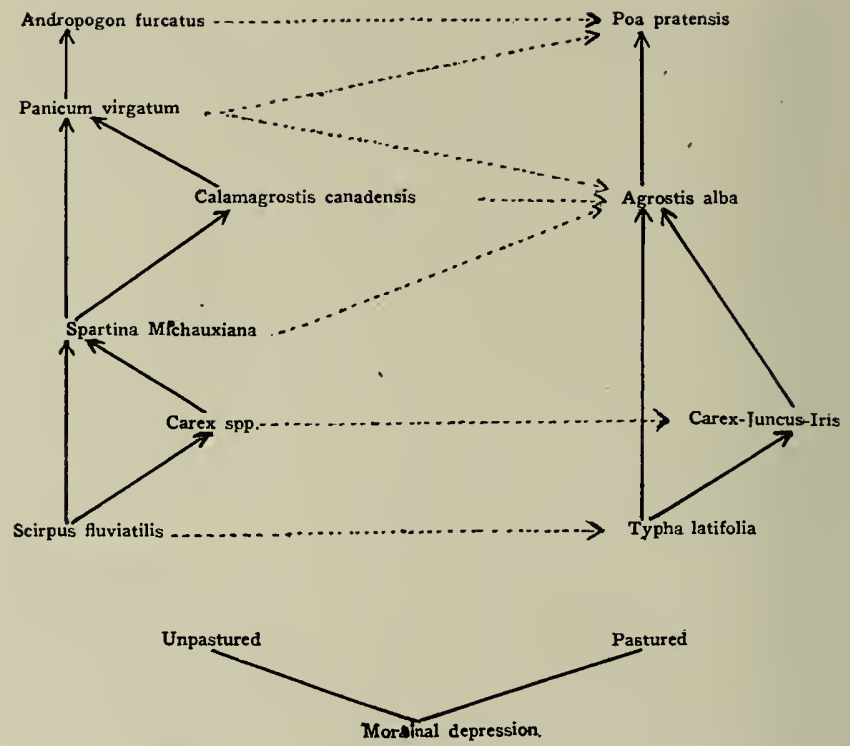

FIG. 5. Diagram showing the plant associations and hydrarch successions in morainal depressions. The dotted lines indicate the changes brought about by grazing.

to a mixture of blue grass with timothy and red top and allowing a few years for the blue grass to establish itself and crowd out the other grasses, except in low places where red top is a dominant pasture grass. On fertile loamy soil this succession will occur within three or four years, but on clay soils a somewhat longer time is required.

With the foregoing associations and their successional relationships in mind it is of interest to compare them with the associations found on the more extensive shallow depressions of the ground moraine. This can be done at present only by having recourse to the relic patches of prairic plants along railway rights-of-way and fence-rows (Plates LXVLXX). When this comparison is made, the same general associations frequently interspersed with patches of coarse herbs and cultivated grasses are met with again in the same order from lowlands to upland. This comparison also shows that most of the prairie areas of the older glaciated regions of the state had reached the Andropogon furcatus stage before they were disturbed by man, while large areas in the Wisconsin 
glaciation were still dominated by Spartina Michauxiana, Calamagrostis canadensis, and Panicum virgatum. Owing to the clean farming methods practiced in this part of the state it is now very difficult to estimate the percentage of swamp prairie formerly occurring on the present well-drained farms. But the postglacial history of this area is still clearly written in the soil. The wide extent of the deep black soils points to a long postglacial period in which swamps dominated by sedges and swamp grasses covered large portions of this glaciation. With the gradual filling and drainage of these extensive swamps the more mesophytic prairies arose. Soil maps showing the comparative depth of the dark humus soil could be used in determining the extent of associations and also in the estimation of land values.

Mr. Wiles estimated that from $\% 0$ to 90 per cent. of the area of the isolated prairie tracts separated by streams near his home in Vermilion county was dominated by an almost pure stand of Andropogon furcatus, the remainder by slough grasses, sedges, and rushes. He stated, however, that more abundant and extensive sloughs were present in the prairie tracts northwest of Vermilion county. Farmers who helped drain Douglas county say that the area formerly covered by sloughs and shallow lakes greatly exceeded the area of tillable land in that county.

\section{THE XERARCH SUCCESSIONS}

\section{The Succession (a) on Upland Glacial Soils}

The succession of associations leading from swamp to the upland prairie was found in every case to terminate in an Andropogon furcatus association. This raises the questions of the amount of the upland prairie soils dominated by this grass and the nature of the successions from the more xerophytic areas on upland glacial soils and sand.

In this survey emphasis was placed upon the WVisconsin and the Lower Illinoisan glaciations. On the former the most typical upland prairie soil is a brown silt loam, on the latter it is a gray silt loam poorer in organic matter and generally less fertile. Both of these surface soil types are underlaid at varying depths with the typical clays of the glacial till. Outcrops of these glacial clays are among the most xerophytic areas of the prairie.

Orving to the value of this type of land for agriculture, it is now practically all under cultivation. The few small relics of Andropogon furcatus prairie in the vicinity of morainal depressions previously discussed and similar patches near forest borders constitute the only prairie tracts of this type found in the Wisconsin glaciation. On the southern Illinoisan glaciation several small tracts varying in size from a fraction of an acre to 2 acres were found. With the exception of the exposed clay areas these are all Andropogon furcatus prairies.

Additional data were obtained from railway rights-of-way, old line-fences, and from individuals who had lived on these prairies be- 
fore they were plowed. Both of these sources of information have their limitations. The railway rights-of-way have been subjected to grading, artificial drainage, annual cutting, and burning, and many have been cultivated at times. As a result the original associations have been frequently greatly modified or entirely destroyed. Natural competition is interfered with, and the observed composition of the associations and habitat-range of individual species may not correspond to original conditions. It is also of interest in this connection to call attention to the fact that patches of natural prairie plants on these rights-of-way may not always be relics of the original prairie but the result of secondary successions culminating in the original prairie plants.

This fact is clearly illustrated in many places along the Indianapolis branch of the Illinois Central Railway. This right-of-way was originally 50 feet wide. In 1897 it was made 80 feet wide by enclosing 15 feet of farm land on each side. The diagram, Figure 6 , represents the succession of associations that has occurred on a strip of this abandoned farm land near my father's farm one mile west of Wheeler in Jasper county.

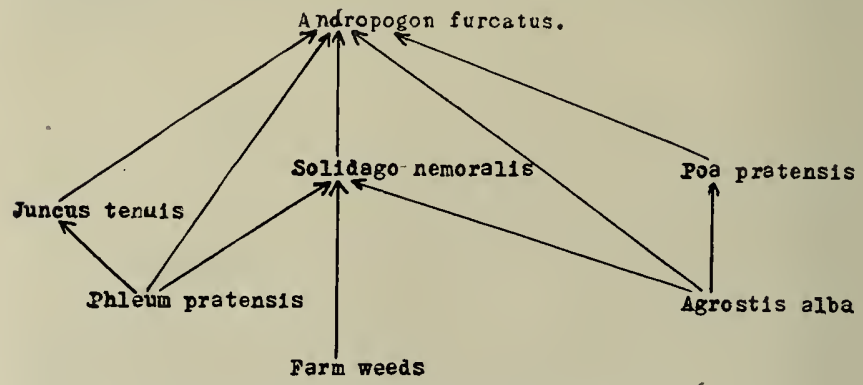

FIG. 6. Diagram showing secondary successions on a railway right-ofway formerly under cultivation near Wheeler, Illinois.

At the time of widening the right-of-way the land on one side of the tract was a timothy pasture, on the other side it was under cultivation. In some places Andropogon furcatus oceurs now in almost pure stand and might well be considered original prairie if its history were unknown. This reversion to the natural prairie plants may be seen anywhere along this right-of-way where a sufficient number of relic prairie plants existed on the old right-of-way.' Another instance of this, on the Baltimore and Ohio Railway in Clay county, is illustrated in Plate LXX. The area now covered with Andropogon furcatus was formerly forested. The greater part of the 90 miles of this right-of-way 
from Odin to Olney is covered by Andropogon furcatus, and much of it is original prairie sod.

Still another type of reversion to the Andropogon furcatus prairie may be seen on eroding banks and slopes along these rights-of-way. Many instances were noted where Andropogon scoparius dominated the slopes of valleys while the upland and base of the slopes were dominated by Andropogon furcatus. The successions of these associations accompanying base-leveling in such cases is obvious. Sorghastrum mutans and Sporobolus hetcrolcpis were also found on these slopes but generally as secondary species. Where erosion is rapid coarse herbs are abundant, but where erosion is slowed down by decreased gradients and consequent greater stability of soil they become scattered secondary members of the grass associations. In cases where the natural grasses have been entirely eradicated these coarse herbs prevail perhaps indefinitely.

In addition to railway rights-of-way in the Illinoisan glaciation old fence-rows harboring relic patches of prairie plants are abundant. When land adjoining these fence-rows is sowed to meadow grasses the cultivated grasses are gradually invaded and crowded out by Andropogon furcatus. One instance was observed where this native grass occupied an area of timothy meadow to a distance of 40 feet, and areas $10-15$ feet in width are common.

With regard to limitations in basing conclusions upon statements made by the early settlers the principle that safety lies in numbers was adhered to, and in practically all cases specimens of the plants in question were at hand. No less than 30 individuals were questioned with regard to the original prairies of the Southern Illinoisan glaciation. Nany of these had spent from 20 to 30 years on the virgin prairies and on account of economic, medicinal, or esthetic reasons were familiar with many species of prairie plants.

The data obtained from the early settlers and a careful study of the prairie relics seem sufficient to reconstruct rather accurately the original prairies of the Southern Illinoisan glaciation. The low prairie was dominated mainly by Spartina Michauxiana, Calamagrostis canadensis, and Panicum virgatum, while the more extensive prairie was dominated by Andropogon furcatus. Coarse herbs grew only as scattered individuals among the grasses. On the exposed clay Andropogon scoparius was abundant, and associated with it were many coarse herbs. A mixed association consisting of the two Andropogons, Sorghastrum nutans, and Sporobolus heterolepis may have occurred in transition zones on some of these clay arcas.

Turning now to the Wisconsin glaciation the same sources of information exist, but they were less fruitful. From the data available it is certain than Andropogon furcatus was the dominant grass of the upland prairies. The points in question concern the probable rôle played by coarse herbs and by more xerophytic grasses, particularly Andropogon 
scoparius, and the probable extent of mixed associations. In the Audropogon furcatus prairies remaining in morainal depressions and the small areas in the vicinity of Chicago coarse herbs occur only as scattered individuals, as in the Southern Illinoisan glaciation. The older writers speak of these prairies as a "sea of grasses", and it is probable that coarse herbs did not occupy very large areas, as their presence would certainly have called forth exclamations from the men of those days. Wherever the prairie grasses have been greatly disturbed along railway rights-of-way, both north and south, these coarse herbs become conspicuous, and this has probably led many to ascribe to them more prominence than they deserve. Gerhard and others report them as being abundant on hillsides and near forest borders, and they may have been rather prominent on the shallow soils of morainal ridges.

The xerophytic grass association dominated by Andropogon scoparius is the characteristic association of these shallow soils. Relic patches of this grass are most frequently found on the broken topography near woodlands where the subsoil has been exposed by erosion. As in the southern part of the state, Sorghastrum nutans, Sporobolus heterolcpis, and coarse herbs are also more conspicuous in these areas. Vestal (28) finds that this association is not very extensively developed in the upper Wisconsin glaciation. The data obtained in this survey agree with his statement.

The available data bearing upon the extent of mixed associations in this region are rather insufficient for quantitative estimates. In the Southern Illinoisan glaciation mixed associations were of minor importance as most of that region had reached the climax stage of development and was dominated by but one species, Andropogon furcatus. It is probable that mixed associations representing a transition stage in succession to this climax from the drier uplands may have been more extensive on the younger topography of the Wisconsin glaciation, but conclusive evidence is wanting.

From my records it appears evident that under the most favorable natural conditions the dominant species shown in the previous diagrams of this report must have occurred in almost pure stands; that coarse herbs were not abundant except on eroding soils and near forest borders; and that mixed associations were limited largely to transition zones. This conclusion was corroborated by every early settler with whom I talked and also by Dr. John H. Schaffner (22), who lived on the Andropogon prairies in Kansas and had many opportunities to see them in their natural conditions. They all report that in the best growing seasons Andropogon furcatus grew so tall that a man sitting on a horse could not see over it, and that the location of cattle and horses could frequently not be determined except by the waving of the tall grass as they passed through it. This height together with its production of a close sod and dense vegetative growth was sufficient to exclude most of the other prairie plants. Dr. Schaffner also reports that Andropogon scoparius generally occurred in very pure stands, and that coarse herbs 
were not abundant in either of the Andropogon associations but might occur abundantly on eroding soils. Some of the plates accompanying this report show these same features for Spartina Michanxiana, Calamagrostis canadcnsis, and Panicum virgatum.

To sum up, both the historical data and the data obtained from relic prairie areas lead to the conclusion that Andropogon furcatus is the climax grass of the whole upland prairie region of the state, and that in the successions leading to this climax from the more xerophytic uplands and exposed clay soils Andropogon scoparius is the most important species. Figure, $f$ shows the successions of associations that may occur in this xerarch series.

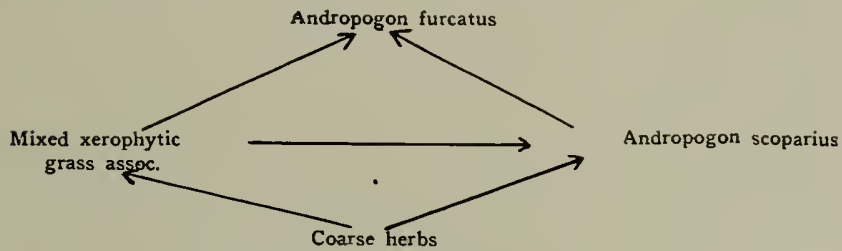

F1G. 7. Diagran showing the principal associations in the xerarch succession on xerophytic upland soils.

During the long postglacial period forests working back from the water courses invaded these upland prairie soils. The progress of this invasion as would be expected is much farther advanced in the Lower Illinoisan glaciation than in the Wisconsin glaciation. While this encroachment of the forest on the prairie is generally considered to have kept pace with the development of drainage and the soil erosion involved, there are rather extensive areas in which the encroaching forest preceded erosion. Since these forest soils bordering the upland prairie soils had the same origin, the differences in them today are largely a result of their fioral history. In this connection the county soil reports (3) have some very interesting data showing the effect of vegetation upon soil types. The organic matter of the forest soils ranges from about $25-50$ per cent. of the amount present in the adjoining prairie soils. This gives the prairie soils a much darker color than the forest soils and is the result of a more complete decomposition of the plant remains of a forest than of a prairie. To quote from one of these reports: "The leaves and twigs of the trees fall upon the surface of the ground and decay completely; whereas the prairie grasses form a mass of roots in the soil which. when they die. are prevented from complete decay by the absence of sufficient oxygen. In this way prairie grasses and other plants cause a gradual accumulation of organic matter. If prairie land becomes forested the organic matter is slowly diminished to a low point." This statement apparently is not intended to apply to flood-plain forests, where deposition during 
overflows is an important factor in soil fertility, nor to the occasional small forest areas that have developed from swamps in which the slowly decaying organic matter accumulates under water during the greater part of the year. The conditions described above are more prominent in the older glaciated regions, where we find the most extensive areas of forest encroachment on pre-erosion topography.

The data in these soil reports also show a lower content of calcium in forest soils than in the adjoining prairie soils. This difference is much more pronounced in the subsurface soils and subsoils than in the surface soils, rendering them more acid than the adjoining prairie soils. Forest vegetation when compared with prairie vegetation therefore retards the accumulation of organic matter and accelerates the drain on calcium. Certain authors have suggested that the greater content of calcium in prairie soils may be one of the causes of the prairie. The above facts indicate that prairie vegetation greatly retards the rate at which calcium leaches from the soil.

The farmers of the state have been slow in recognizing this effect of the floral history upon the present value of soils. In my own community in the Southern Illinoisan glaciation the clearing and cultivation of forested areas always seemed to have an alluring appeal entirely unrelated to economic values. Many of the farmers continued to clear the forest in spite of the fact that some of the forested areas after ten to fifteen years of cultivation yield no better crops than adjacent prairie areas that have been cultivated for forty years. Many of the slopes formerly protected. by forest vegetation have been cleared, farmed for a few years, and then abandoned to the forces of erosion. An intelligent constructive forest policy that can be taught and convincingly explained to the farmers is the only hope for remedying these regrettable conditions.

\section{The Xerarch Succession (b) an Sand}

The sand prairies of the state have been described in detail by Gleason $(9,10)$ and Vestal $(27)$; consequently they have received only minor attention in this survey. The following description deals mainly with the more general features which tend to show the relation of the floral successions on sand to those of the soil types previously discussed. Both of the above sources of information have been drawn upon in this report. Evidence collected by Gleason shows that most of the sand prairies were covered with a carpet of vegetation when settlements were begun in this region. Subsequent plowing and pasturing, however, has led to the exposure of large areas of sand to wind action and the development of "blowouts". Owing to frequent movement of the sand by wind, the revegetation and stabilization of these xerophytic sand areas is a slow process, and progressive successions are often less prominent than retrogressive ones. The most xerophytic prairies of the state occur in these sand areas, and as Gleason has already pointed out we have here the greatest representation of typically western plants. In fact the 
regetation of the more xerophytic sand areas is more representative of the sand-hill vegetation of Kansas and Nebraska than of the Great Plains or the Prairie.

With the establishment of a pioneer association sufficient to prevent the erosive action of the wind, conditions become less severe and further growth of a less xerophytic type is favored. As the vegetation encroaches and establishes itself upon the sand, the accumulation of organic matter from decaying roots and tops of successive associations results in physical changes in the soil which slowly approach conditions existing on the more mesophytic prairies. The more important of these changes is a decrease in the extremes of temperature and an increase in humus with a consequent increase in soil stability and soil water. Gleason (10) has shown that the evaporation rate of the air also gradually decreases from one association to another. Each association thus improves conditions and paves the way for its successor, ultimately leading to the climax association of the region.

Observations were made on the sand areas at Hanover, between Savanna and Albany, at Oregon, and in the northwestern part of Bureau county. The succession of the principal associations leading to prairie in these areas is given in Figure 8.

The Panicum pscudopubescens association is most frequently found in the vicinity of blowouts, where it is a stage in the retrogressive succession from the bunch-grass association to the blowout association. Plate LXYI represents such a stage with the blowout just beginning, and shows the relative amount of the sand that may be occupied by this species. The secondary species are relics of the bunch-grass associations previously destroyed by the wind.

With the further development of the blowout Panicum pseudopubescens is replaced by the blowout association, which Gleason further subdivides into four distinct "associations." First, the basin of the blowout, where the sand is being removed by the wind. The vegetation of this "association" is very meager and is composed of a few scattered perennials persisting from the Panicum fscudopubescens association. Chief among these are Accrates viridiflora and its varieties lanceolata and linearis, Lithospermum Guelini, Euphorbia corollata, and Lespedcá capitata. Second, the windward slope, where the sand is being removed by both wind and gravity. The vegetation of this "association" consists of relics of the Panicum pseudopubescens and bunch-grass associations which have been undermined at the top and have gained a foothold while sliding down the slope. This association is limiter to perennials, among the most important of which are Panicum pseudopubesecns and Selaginclla rupestris. Third, the lee slope, or "blowsand association," over which the sand is being sprayed by the wind. The vegetation of this association consists mainly of annuals characteristic of the bunch-grass association. Gleason lists 31 species for this association, of which Aristida tuberculosa is the pioneer. This species is common to all the areas studied. Other important species such as Diodia teres, Paspalum setaccum, Commelina 


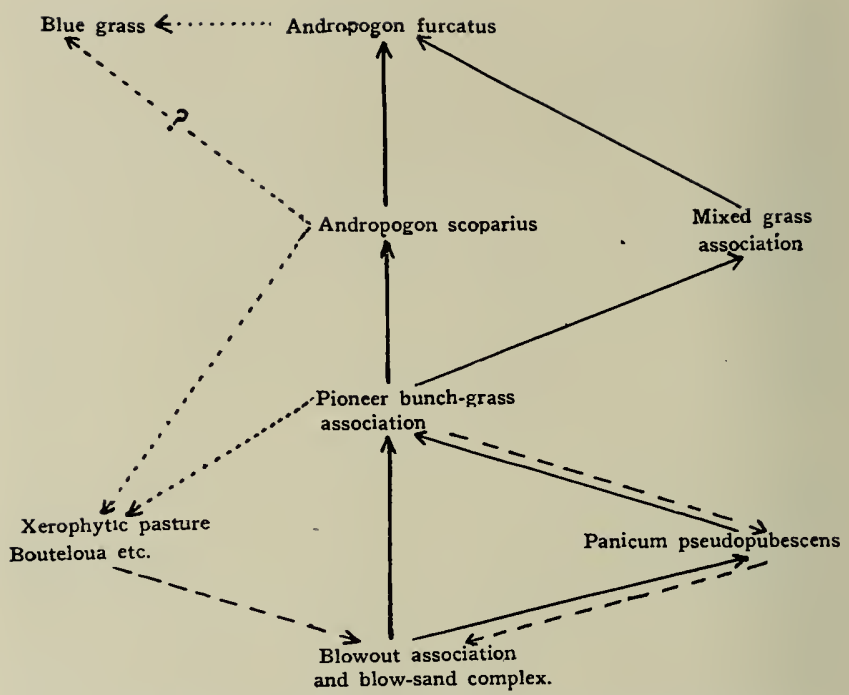

Fig. 8. Diagram showing the, interrelation of the principal associations leading to prairie on sand. The broken lines represent retrogressive successions resulting from blowouts. The dotted lines represent successions resulting from grazing. See Plates LXXI-LXXV.

virginica, and Conchrus carolinianus are more local in their distribution. Lastly, the "deposit association," composed chiefly of such dune-forming species as Rhus canadensis, var. illinoensis, Ceanothus americanus, Tcphrosia virginiana, Panicum virgatum, and occasionally Calamovilfa longifolia. To this list Vestal (2\%) proposes to add a fifth association, the "blowsand complex", which arises from the continued growth of a large blowout or by the confluence of a number of blowouts. The vegetation is variable and is composed mainly of annuals as in the case of the blowsand association.

The meager vegetation of these five "associations" is of little consequence in the stabilization of the sand. The first permanent step in the development of vegetation on denuded areas is accomplished by the pioneer bunch-grasses which succeed in getting a foothold in any of these associations. Sclaginella rupestris is also an important pioneer invader in these areas at Hanover and Savanna. The order of the entrance of the grasses is not definitely known, though, as Gleason has pointed out, it depends largely upon the nature of the neighboring areas of the 
bunch-grass association. Invasion may be affected by a single species or by two or more species in common. The most important of these pioneers observed by the writer are Panicum pscudopubescens, Paspalum sctaccum, Sporobolus cryptandrus, Lcptoloma cognatum, Carex Mullenbcrgii, and Cyperus Schacinitzii. On the deposit associations Panicum virgatum may serve as the starting point of the bunch-grass association.

The pioneer bunch-grass association may be dominated by a single species or by a mixture of several species. The most important of the grasses in addition to those listed above are Bouteloua hirsuta, $B$. curtipendula, Eragrostis pectinacea, Kocleria cristata, Stipa spartea, and Andropogon scoparius, all of which may occur as local dominants. IVith decrease in xerophytisn the pioneer bunch-grasses are replaced by Andropogon scoparius or a mixed grass association in which both species of Andropogon and sometimes Sporobolus hcterolepis are the prominent members. Sorghastrum nutans and Panicum Scribnerianum also increase in abundance in these associations. At first the secondary species are largely relics of the former bunch-grass association, but in the later stages these are largely crowded out by Andropogon and partly replaced by secondary species common to the Andropogon prairies elsewhere in the state. In the most mesophytic stage of the Andropogon scoparius association the open tuft-like growth characteristic of the pioneer bunchgrass association is replaced by a close sod (Plate LXXIV). These associations are not abundant today and were found only on low dunes, in depressions between dunes, and on railway rights-of-way where they had been least disturbed by agricultural practices.

The most mesophytic areas of the sand are dominated by Andropogon furcatus. Vestal (2\%) reports Audropogon furcatus dominating parts of the "black-soil transition association" on sand which he finds has reached its most advanced stage in the Havana region "in places near Devil's Neck, in places east of the several forested dune areas, and particularly at the eastern border of the sand plain". Most of the sand prairies of this type have been either plowed or pastured. Plate LXXV shows an almost pure stand of Andropogon furcatus on a low dune some two miles south of Savanna. This dune is probably not more than 20 feet above the river. One side grades off into the flood-plain, and the remaining three sides are bordered by small lakes. It has escaped both plowing and pasturing. About half of the dune is dominated by Andropogon furcatus, the remainder by Andropogon scoparius. A similar area was found toward the base of a sand dune adjoining a swamp preserved for hay in the northern part of Bureau county. The older residents of this region report an abundance of tall bluestem on the low sand hills between the swamps, and an abundance of both tall and low bluestem, frequently mixed with other grasses, on the higher dunes.

A large part of the sand area in Bureau county has been subjected to pasturing, and a blue-grass pasture has resulted in many cases. When the pioneer bunch-grass association or an early stage of the Andropogon 
scoparius association on sand is pastured, a xerophytic pasture results in which the prominent species are Bouteloua hirsuta, Leptoloma cognatum, Panicum pseudopubescens, Paspalum, setaceum, Eragrostis pectinacea, and Cyperus Schweinitzii. The presence of the blue-grass pastures therefore indicates a rather advanced stage in the development of the sand prairie, probably either a late stage of the Andropogon scoparius or mixed grass association, or an Andropogon furcatus association.

Apparently this last association was rarely developed on the higher sand areas. Gleason estimates that on the sand prairies as a whole at least two thirds of the surface was originally occupied by a mixed bunch-grass association varying all the way from areas dominated by the pioneer grasses to those in which the Andropogons were abundant.

It would be of interest to both plant ecologists and farmers if a tract of the present cultivated sand prairies of the Savanna region could be set aside and allowed to revert undisturbed to natural conditions. The ecologist could determine more definitely the order of succession of the natural grasses on sand. At the same time the agriculturist would have a means of determining how long it would be necessary to allow his sandy farm to remain undisturbed in order to obtain a permanent bluegrass pasture to take the place of present poor crops and shifting sand. On the areas of pure sand many years would be required, but on most of the area where humus has accumulated from the natural vegetation of former years the time required might be commensurate with the returns.

In Figure 9, a summary of the succession of the principal associations of the natural prairie plants is given. Associations of weeds and cultivated grasses now present on the prairie as a result of the influence of civilization are omitted in this summary.

\section{Composition of the Associations}

In the preceding discussion of the associations emphasis is placed on the dominant species. Following is a list of the associations together with some of the more frequent secondary species found on less disturbed areas. This list made from small relic areas is not meant to be complete nor to represent absolutely the composition of the more extensive associations before they were disturbed by man. Certain limitations must be recognized. In the first place, the composition of an association is usually most representative near its center of distribution, and least representative near its boundaries where there is an overlapping of secondary species of adjacent associations. The centers of distribution of some of the associations have been entirely destroyed by cultivation, and only the boundaries remain for study. Under present conditions it is impossible in every case to list the secondary species with the association in which they were most common. In the second place, 


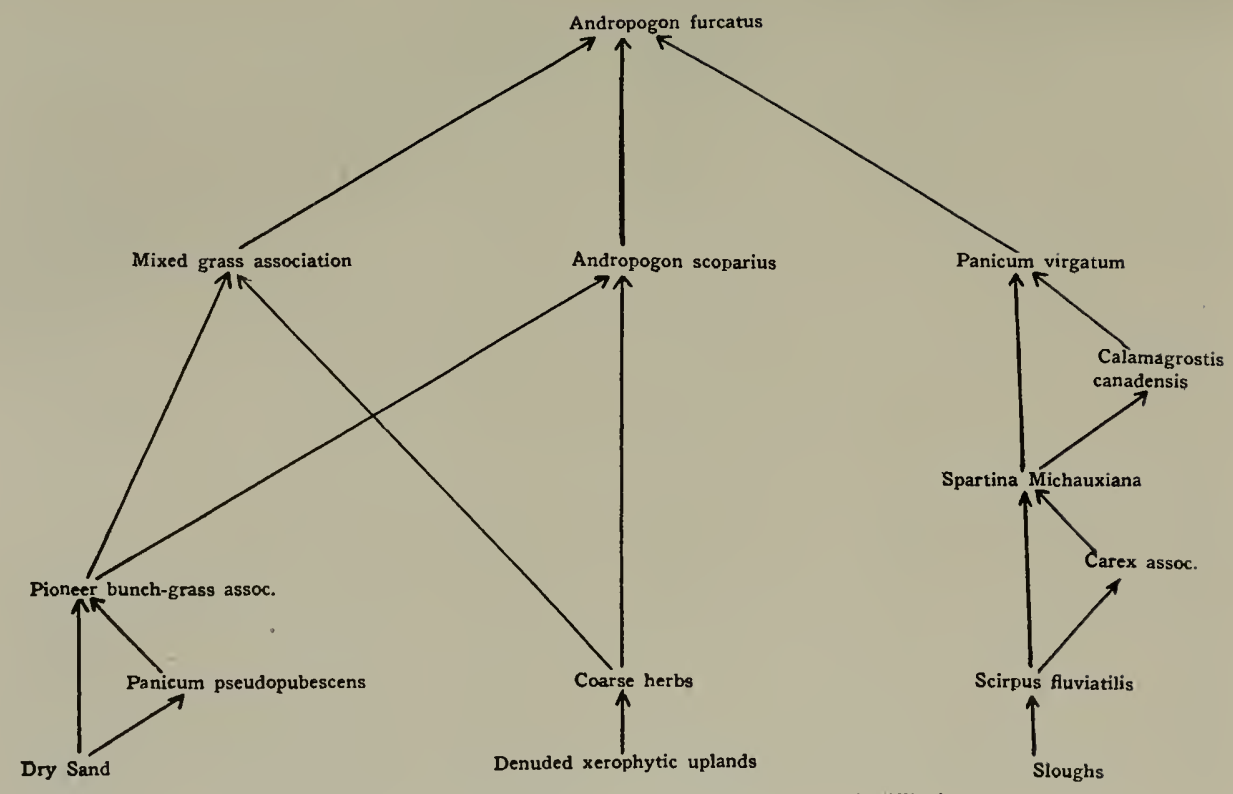

Fig. 9. A genetic classification of the prairie plant-associations in Illinois. 
the habitat range of any species is more extensive when the biotic factors of competition are removed than when they are present. The numerous disturbances accompanying civilization usually eliminate the influence of biotic factors, at least in part, and admit not only a greater prominence of secondary species but also a wider edaphic range of all species than existed under natural conditions. Recently drained sloughs may be found in which Spartina still persists as the dominant plant, but the Spartina association in such cases may have as secondary species mostly plants characteristic of the Andropogon associations. It is obvious that a detailed account of associations under disturbed conditions is not only valuless but is confusing to the uninitiated. Secondary species of local prominence following drainage, grazing, or other disturbance are not included in the list below unless they were found to occur frequently in the same associations elsewhere. A more complete list of secondary species of any association may be obtained from the annotated list beginning on page 559 of this article.

The Scirpus fuviatilis Association.-Scirpus fuviatilis, S. validus, Glyceria septentrionalis, Sparganium curycarpum, Acorus Calamus, Sagittaria latifolia, Sium cicutaefolium, Pontederia cordata, Alisma Plantago-aquatica, Rumex verticillatus, Polygonum Muhlenbergii, $P$. hydropiperoides, P. amphibium, Eleocharis palustris, E. acicularis, Penthorum sedoides, Scutellaria galericulata, Ludvigia palustris, Mimulus ringens, and Ranunculus delphinifolius.

Typha latifolia and sometimes Phragmites communis occur in this association when there has been some disturbance, such as tramping by grazing animals, pollution of the water, and dredging. With continued disturbance Scirpus fuviatilis disappears, and Typha latifolia dominates except for small colonies of Phragmites communis in some localities. The data obtained in this survey indicate that neither Typha nor Phragmites was abundant in the natural prairies of the state. Scirpus validus may form an association in deeper water beyond Scirpus fuviatilis. In the shade of trees Sagittaria latifolia usually replaces Scirpus fluviatilis.

Forest invasion of this association may occur. The principal invading species noted are Cephalanthus occidentalis, Cornus stolonifera, Salix amygdaloides, S. nigra, S. cordata, S. discolor, and S. longifolia.

The Carex Association.-This association needs considerable more attention than it received during this survey. Carex vesicaria appears to be the most important dominant species on flood-plains and in some of the morainal depressions, but other species were also noted as dominants, namely, $C$. lanuginosa, $C$. stricta, C. Sartwellii, and $C$. vulpinoidea. The secondary species are: C. rostrata, C. lupulina, C. tribuloides, $C$. straminea, C. stipata, C. pennsylvanica, Scirpus atrovirens, Lobelia cardinalis, Steironema lanceolatum, Veronia fasciculata, $V$. altissima, Eupatorium perfoliatum, Asclepias incarnata, Stachys tenuifolia, Eleocharis palustris, E. obtusa, E. intermedia, Leersia oryzoides, and Phalaris 
arundinacea. These last two species may occur as local dominants between Scirpus fuviatilis and Spartina Michauxiana, and they may have been prominent in this position on the original prairies.

The Spartina Michauxiana Association-Spartina Michanxiana, Elymus virginicus, Phalaris arundinacea, Leersia oryzoides, Glyceria nervata, Carex vulpinoidea, C. Bebbii, C. scoparia, $C$. lanuginosa, $C$. tribuloides, Elcocharis palustris, E. obtusa, E. intermedia, Juncus nodosus, J. Torreyi, J. tenuis, Cyperus strigosus, Stacliys palustris, Lythrum alatum, Vermania fasciculata, $V$. altissima, Steiranema lanccolatum, Lycapus ancricanus, Aster paniculatus, Asclcpias incarnata, Apocynum camnabinum var. hypericifolium, Hypericum ellipticum, Iris acrsicolor, Lippia lanceolata, Senecio aureus, and S. Balsamitac.

Forest invasion may occur in this association by the species noted aboye and also by Populus deltaides, less frequently by $P$. grandidentata or $P$. tremuloides, and Cormus Amomum.

The Calamagrastis canadensis Association.-Calamagrastis ine.lpansa, Aspidium Thelypteris, and Onoclea scnsibilis were found to be more abundant in this association than elsewhere, but the remaining secondary species consist largely of an overlapping of the secondary species of the Spartina and Panicum associations. This condition agrees well with the fact that the Calamagrostis association is sometimes eliminated in the succession from Spartina to Panicum virgatum.

The Panicun virgatum Association.-Panicum virgatum, $P$. Lindhcineri, $P$. huachucac, $P$. tennesscense, Elymus virginicus, E. canadensis, Ranunculus fascicularis, $R$. scptentrianalis, Baptisia lcucantha, Anemone canadensis, Oxalis carniculata, Cicuta maculata, Stcirancma ciliatum, Plyysostegia virginiana, Veronica virginica, Liatris spicata, Salidaga seratina, S. Riddellii, Cacalia tuberosa, Lathyrus palustris, Rudbeckia hirta, Stachys palustris, and Gaura bicunis.

Forest invasion in this association on the flood-plain at Savanna was found occurring by three different methods: (1) by tree seedlings along the forest borders in the shade of overhanging branches which had eliminated the Panicum, $(2)$ encroachment of Cornus and Crataegus by means of adventitious buds from the roots extending into the prairie, and ( 3 ) by scattered seedlings of Fraxinus americana, Ulmus amcricana, $U$. fulva, and Populus deltaides on the prairie. A recent fire in a small section of this prairie had destroyed most of the seedlings less than six feet in height.

The Andropogon furcatus Association.-Audropagan furcatus, Sorghastrum mitans, Panicum implicatum, P. praccacius, P. Scribncrianum, Sisyrinchium angustifalium, Comandra umbellata, Fragaria virginiana, Baptisia leucantha, Crotalaria sagittalis, Petalastemum purpureum, $P$. candidum, Desmadiun illinaense, D. sessilifolium, Lespedeza capitata, Oxalis carniculata, Palygala sanguinea, P. verticillata, Eupharbia Preslii, 
Hypericum punctatum, H. Drummondii, H. gentianoides, Viola papilionacea, $V$. pedatifida, $V$. sagittata, Phlox glaberrima, P. pilosa, Gaura bicnnis, Eryngium yuccifolium, Dodecathcon Meadia, Asclepias tuberosa, A. Sullivantii, Acerates floridana, Pycnanthemum flexuosum, Vcronica virginica, Ruellia ciliosa, Vernonia illinoensis, $V$. missurica, Liatris squarrosa, L. spicata, Solidago nemoralis, $S$. graminifolia, Aster multiflorus, Silphium laciniatum, $S$. terebinthinaceum, Parthenium integrifolinm, Heliopsis helianthoides, H. scabra, Rudbeckia hirta, R. triloba, Lepachys pinnata, Helianthus mollis, $H$. grossescratus, Coreopsis palmata, Cacalia tuberosa, C. atriplicifolia, Lactuca canadensis, and Prcnanthes aspera.

Forest invasion in this association in the absence of erosion is similar to that described for Panicum virgatum (p. 555). See plates LXXVI, LXXVII.

The Andropogon scoparius Association.-Andropogon scoparius, Sorghastrum nutans, Panicum Scribnerianum, Stipa spartea, Aristida oligantha, Sporobolus heterolepis, Danthonia spicata Comandra umbellata, Cassia Chamaecrista, Tephrosia virginiana, Lespedeza capitata, Euphorbia corollata, Eryngium yuccifolium, Asclepias verticillata, Scutellaria parvula, Pentstemon hirsutus, Ruellia ciliosa, Diodia teres, Kuhnia cupatoriodes, Liatris scariosa, Solidago nemoralis, S. rigida, S. graminifolia, Aster cricoides, A. depaupcratus, A. multiflorus, Brauneria pallida, Helianthus mollis, and Coreopsis palmata.

Most of these plants are also found as secondary species on wellestablished Andropogon scoparius associations on sand such as the one shown in Plate LXXIV. There are also. certain secondary species in this association remaining as relics from more xerophytic associations on sand: Ambrosia, psilostachya, Callirhö̈ triangulato, Bouteloua hirsuta, Helianthus occidentalis, Aster sericeus, A. linarifolius, Cyperus filiculmis, and Koeleria cristata. Many others occur during the earlier stages of the Andropogon associations on sand.

The secondary species of the mixed grass association on sand are practically the same as those listed for the Andropogon scoparius association.

The chief grasses in the pioneer bunch-grass and Panicum pseudopubcscons associations on sand have already been listed. Further details regarding secondary species in these two associations may be obtained from the annotated list or, better, from Gleason's paper (9) on "The Vegetation of the Inland Sand Deposits of Illinois."

The association of coarse herbs on denuded and eroding soils is rather variable, depending upon the water content of the soil and the proximity of plants producing seeds. Several farm weeds and many of the coarse herbs listed for the two Andropogon associations may occur on these areas and in a great variety of different combinations. 
The Relation of Prairie and Forest in Illinois.

The general rclations of prairie and forest in the state have already been noted, and some of the invading forest species were listed with the secondary species of the prairie associations. Apparently any of the prairie associations may be invaded by forest under the present conditions. Four methods of invasion were noted: (1) forest invasion accompanying erosion by streams, (2) growth of tree seedlings along forest borders where the grasses are checked by the shade of overhanging branches, (3) the occasional establishment of isolated seedlings farther out on the prairie, and (4) the growth of adventitious branchbuds from the roots of certain trees and shrubs extending short distances into the prairie. See Plates LXXVI and LXXVII.

Many of the early writers clain that wherever the prairie was protected from annual fires the forest gradually encroached upon the grass-land. A quotation from Gerhard is interesting in this connection: "The first efforts to convert prairies into forest land were usually made on the part of the prairie adjoining the timber. A range of farms, which girded the entire prairie along its circumference having been established, three furrows were plowed all around the settlements in order to stop the burning of the prairie for the whole distance of the circuit in the neighborhood of these farms; whereupon the timber quickly grows up spontaneously on all the parts not burned, the groves and forests conmencing a gradual encroachment on the adjoining prairies, so that one after another concentric circle springs up inside of the preceding. and thus the entire prairie is steadily narrowed from all sides until it is finally occupied, forning a vast region covered with timbers and farms."

Whether all of the prairie area of Illinois would have ultimately become forested under natural conditions is a matter of speculation. Within a few decades man has drained the sloughs and destroyed the prairie turf through cultivation with the result that trees may now be grown throughout the state. The development of natural drainage would no doubt in time have reduced the area of sloughs, destroyed a limited amount of prairie turf, and led to an increase of forested area. A basis of fact for this conjecture is found in the older glaciated regions with their older and better-developed drainage systems where forest occupies a greater proportion of the area than on the youthful topography of the more recently glaciated region. But forest invasion on the better-drained Andropogon prairies is exceedingly slow, and the existence of rather extensive Andropogon prairies on the older glaciated regions of the state shows that prairie vegetation may dominate for many thousands of years.

When the Deciduous Forest Formation comes into competition with the Prairie Formation, the Andropogon furcatus Association may be succeeded by several of the associations of the Deciduous Forest Formation. This is not to be interpreted as saying that the Prairie Formation is a transition between Plains Grass-land and Forest ; neither is it to be 
understood as one of the series of successions leading to the Deciduous Forest Climax. When the Prairie Formation is succeeded by Deciduous Forest associations, it is exactly the same phenomenon that occurs when the Deciduous Forest invades and succeeds the Northern Evergreen Forest Climax-the Abies-Picea-Betula Association. Only in this sense is the Andropogon furcatus Association a temporary climax.

We must therefore conclude that the Andropogon furcatus Association is the climax association of the true prairies.

Where the prairie grades off almost imperceptibly into Plains vegetation there is an intermediate region in which it is too dry for Andropogon furcatus and in which the Andropogon scoparius association is the climax association of the prairie. In this intermediate region in the hydrarch succession, Andropogon furcatĩs is succeeded by Andropogon scoparius.

\section{Annotated List of Species}

No attempt was made to make a complete list of all the prairie species in the state. The following list is added primarily to give a more complete record of the secondary species of the different associations, and an attempt is made to check them with reference to the associations in which they are most usually found. Introduced species, ruderals, and species found only on railway rights-of-way or greatly disturbed areas are listed usually without reference to associations. Some of the weeds and most of the species characteristic , of forest borders and small forest openings, which do not extend very far out on the prairie, are omitted. This list, compiled from small relic areas and under the present disturbed conditions, is subject to the limitations previously discussed and can only approximate the distribution under natural conditions. Consequently reference is made only to the more prominent associations. These associations are referred to in the tabulation by initial letters as follows: S. f. a., Scirpus fuviatilis association, C. a., Carex association, S. M. a., Spartina Michauxiana association, C. c. a., Calanagrostis canadensis association, P. v. a., Panicum virgatum association, A. f. a., Andropogon furcatus association, A. s. a., Audropogon scoparius association, M. g. a., Mixed grass association on sand, P. b-g. a., Pioneer bunch-grass association on sand, P. p. a., Panicum pseudopubescens association. The nomenclature follows the Vienna Code. as given in the seventh edition of Gray's Manual. 


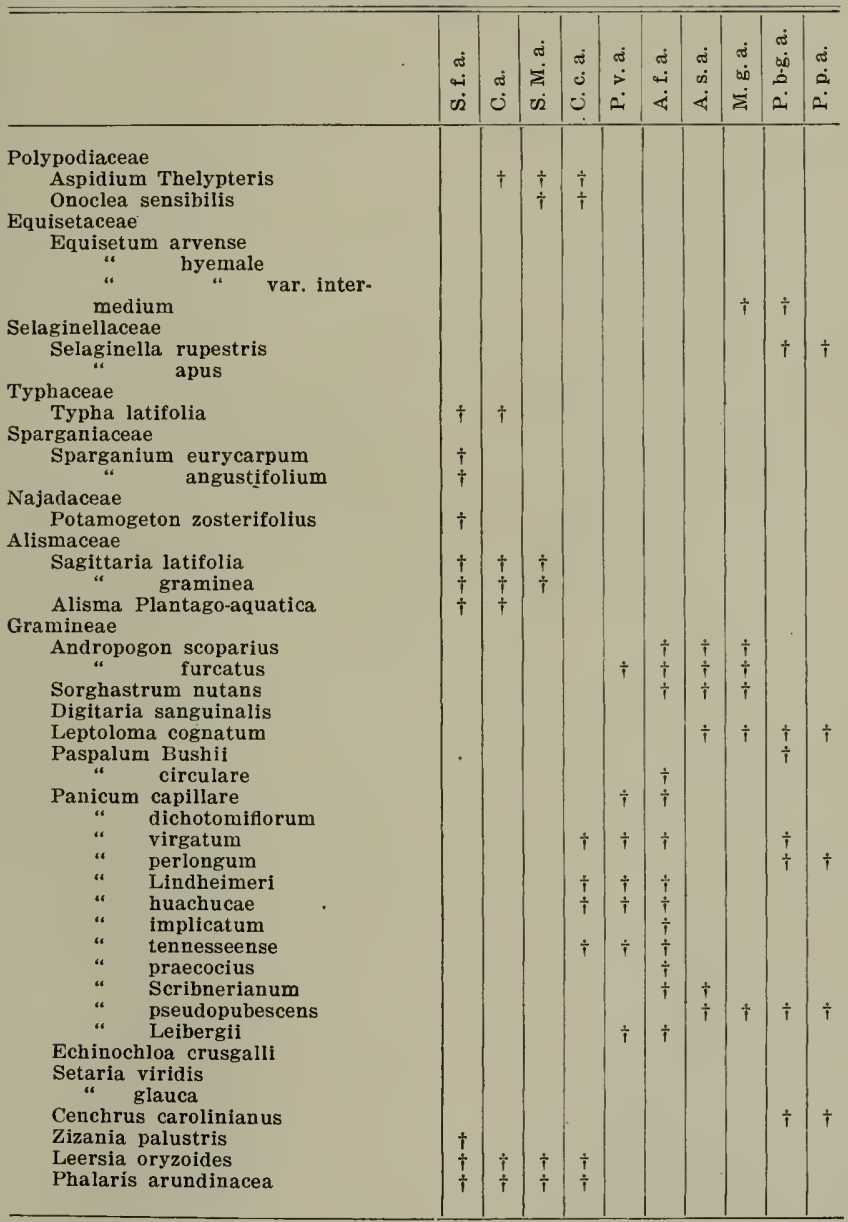




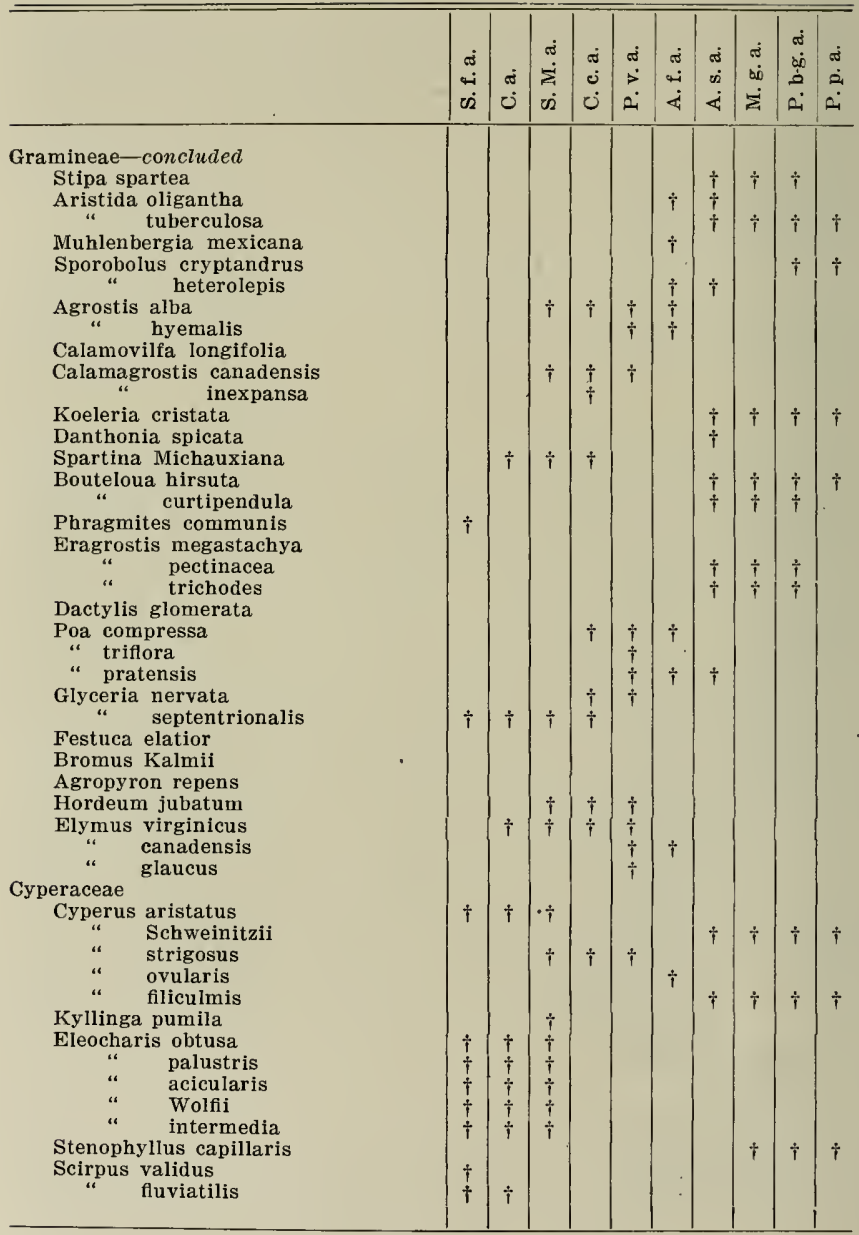




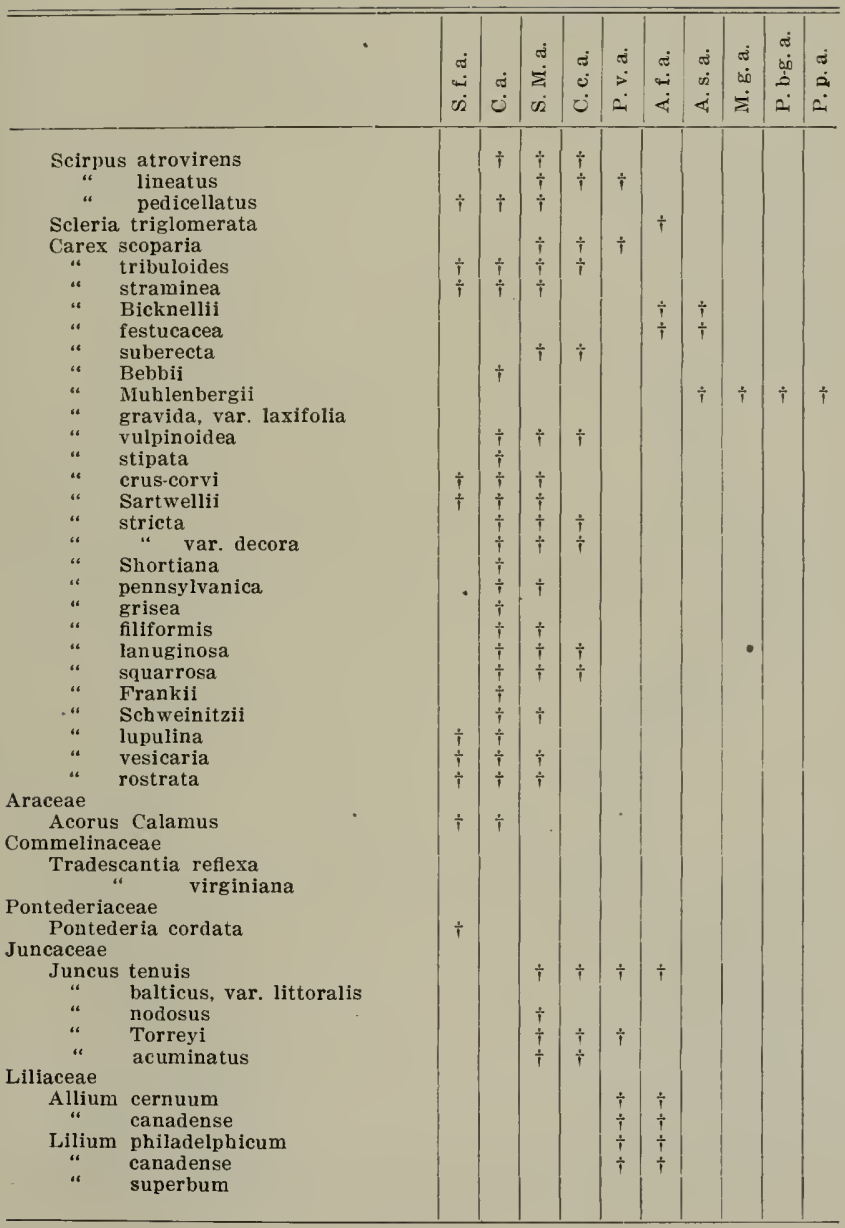




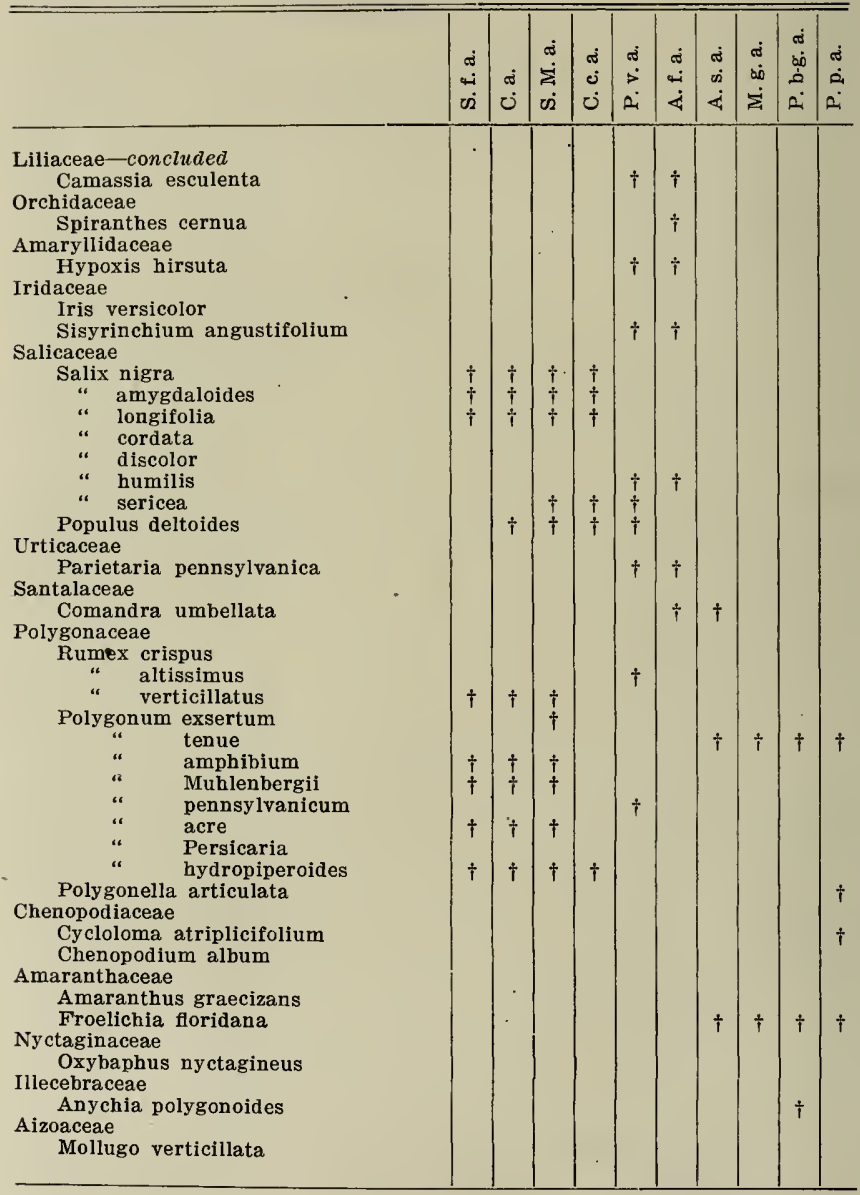




\begin{tabular}{|c|c|c|c|c|c|c|c|c|c|c|}
\hline & $\underset{\dot{\infty}}{\dot{\infty}}$ & 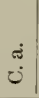 & 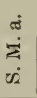 & $\begin{array}{l}\text { ¿ें } \\
\dot{0}\end{array}$ & 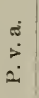 & $\begin{array}{l}\text { मे } \\
\text { i } \\
\dot{4}\end{array}$ & $\begin{array}{l}\text { के } \\
\text { on } \\
\dot{4}\end{array}$ & $\begin{array}{l}\dot{3} \\
\dot{0} \\
\dot{z} \\
\dot{z}\end{array}$ & 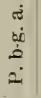 & 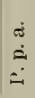 \\
\hline 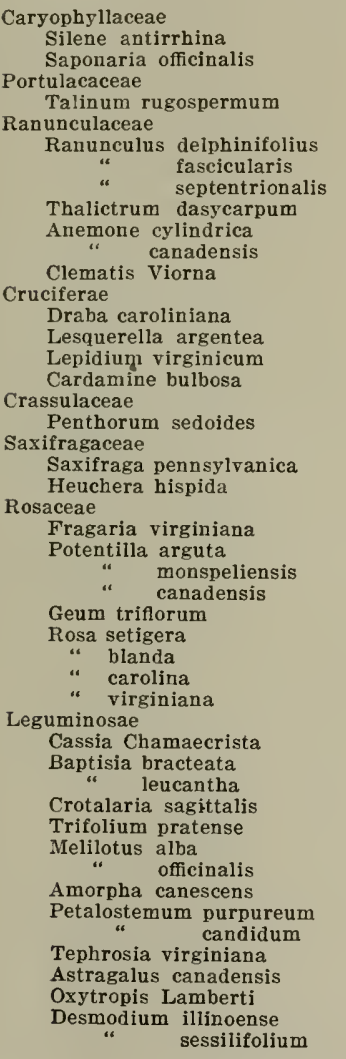 & $\dagger$ & $\frac{\vdots}{\dagger}$ & $\begin{array}{l}\dot{\dagger} \\
\dagger\end{array}$ & $\grave{\dagger}$ & $\begin{array}{l}\vdots \\
\dagger \\
\dagger \\
\dagger\end{array}$ & $\begin{array}{l}\dagger \\
\dagger \\
\dagger \\
\dagger \\
\dagger \\
\dagger \\
\dagger\end{array}$ & $\begin{array}{l}+ \\
+\end{array}$ & $\dagger$ & $\begin{array}{l}\grave{\dagger} \\
\grave{\dagger}\end{array}$ & $\dot{\dagger}$ \\
\hline
\end{tabular}




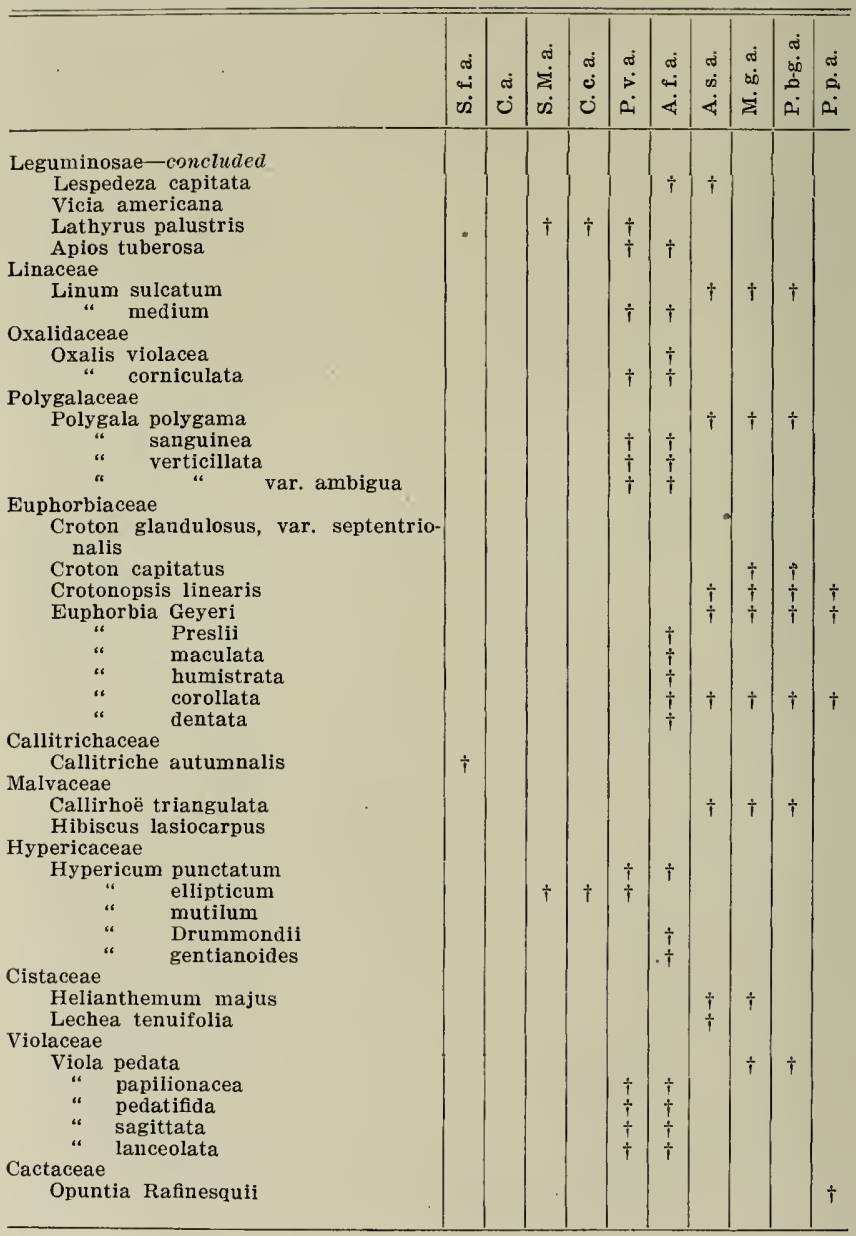




\begin{tabular}{|c|c|c|c|c|c|c|c|c|c|c|}
\hline & $\begin{array}{l}\dot{\sigma} \\
\dot{\text { ஸे }} \\
\dot{2}\end{array}$ & نं & $\underset{\dot{z}}{\dot{j}}$ & $\begin{array}{l}\dot{0} \\
\dot{0} \\
\dot{0}\end{array}$ & $\begin{array}{l}\stackrel{8}{\circ} \\
\dot{0} \\
\dot{0}\end{array}$ & ـ & $\begin{array}{l}0 \\
\dot{0} \\
\dot{\alpha} \\
\end{array}$ & $\begin{array}{l}\text { bं } \\
\text { bो } \\
\dot{\sum}\end{array}$ & $\begin{array}{l}0 \\
\dot{0} \\
\dot{0} \\
\dot{0}\end{array}$ & $\stackrel{\leftrightarrow}{\stackrel{0}{\circ}}$ \\
\hline 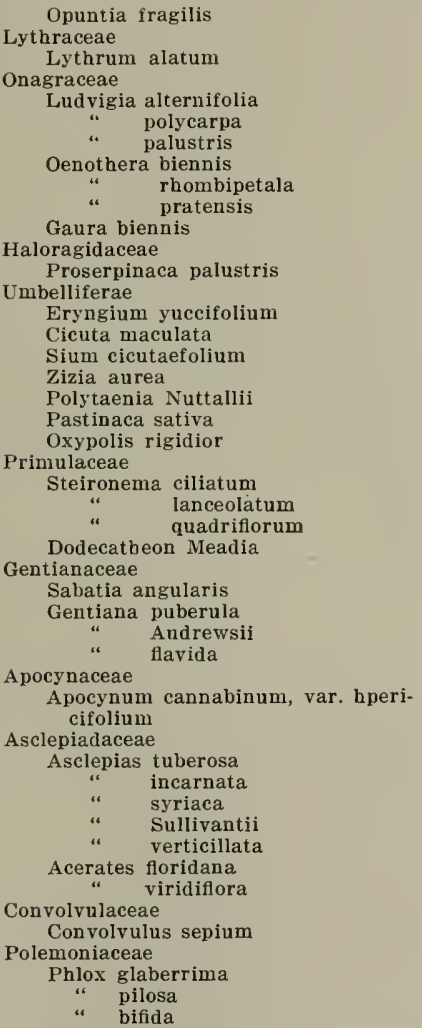 & $\dot{\dagger}$ & $\frac{t}{t}$ & $\begin{array}{l}\dagger \\
\dagger\end{array}$ & 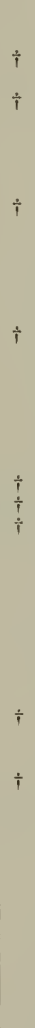 & $\begin{array}{l}\dagger \\
\vdots \\
\vdots\end{array}$ & $\begin{array}{l}\dagger \\
\vdots \\
\vdots \\
\vdots \\
\vdots \\
\vdots\end{array}$ & $\dot{\dagger}$ & $\dagger$ & $\dagger$ & $\dot{\dagger}$ \\
\hline
\end{tabular}




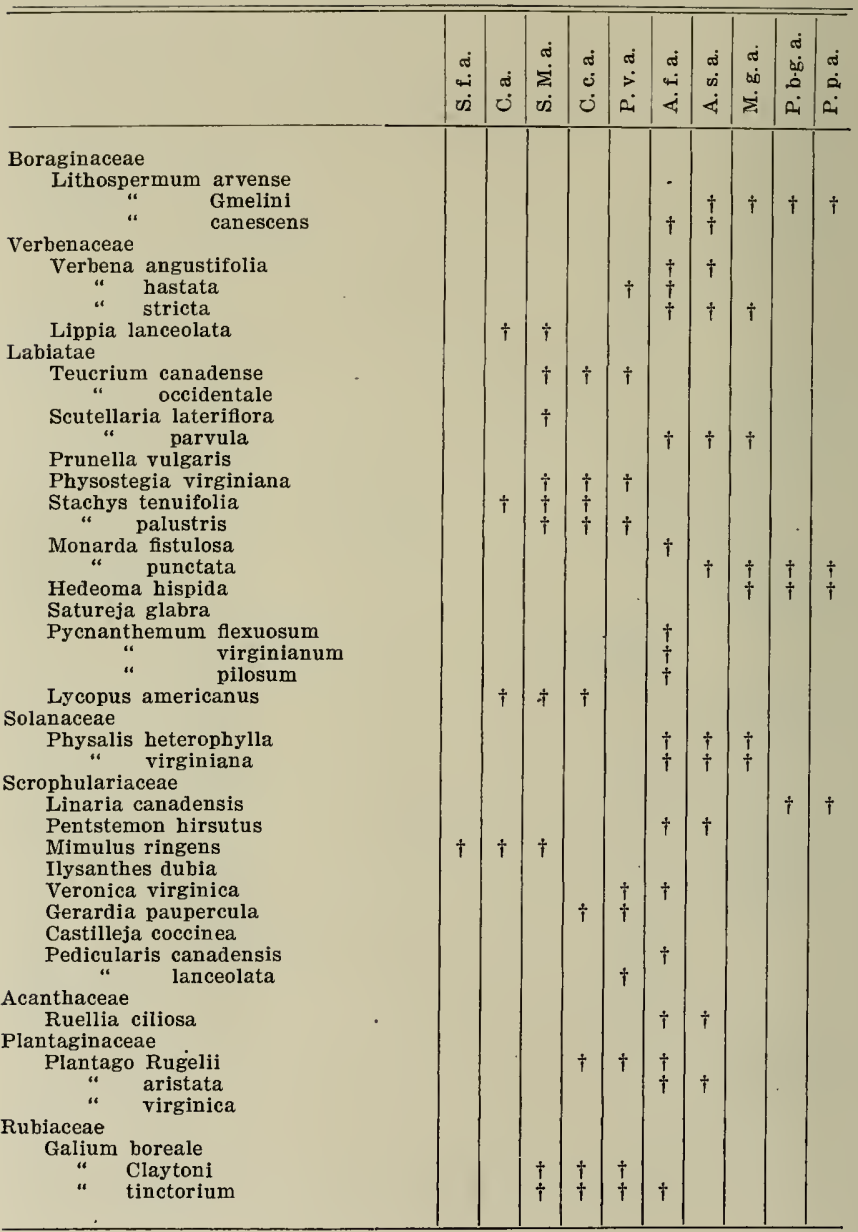




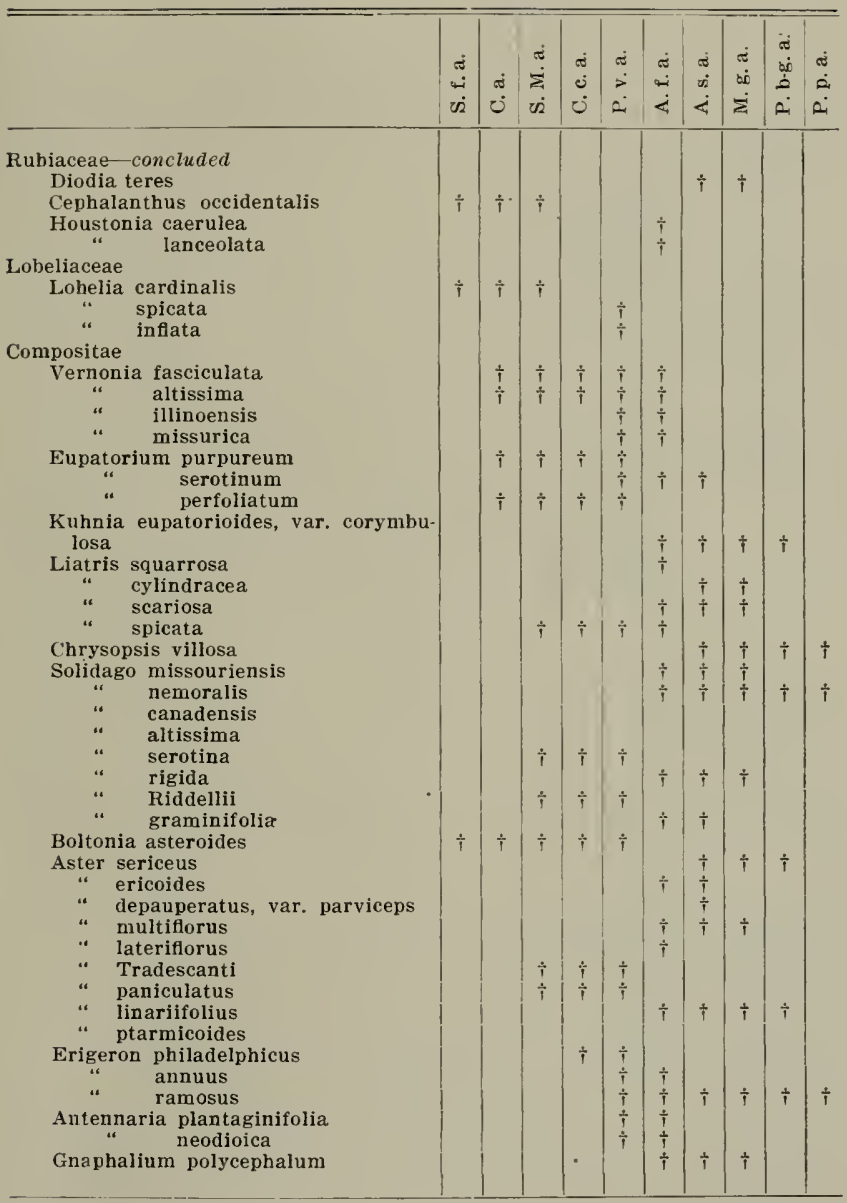




\begin{tabular}{|c|c|c|c|c|c|c|c|c|c|c|}
\hline & ن. & ठ & $\underset{\dot{\Sigma}}{\dot{\Sigma}}$ & $\begin{array}{l}\text { dं } \\
\dot{0} \\
\text { ¿े }\end{array}$ & $\frac{\pi}{2}$ & सं & $\begin{array}{l}\text { d } \\
\text { on } \\
\dot{\alpha}\end{array}$ & $\begin{array}{l}\text { a } \\
\dot{\infty} \\
\dot{\Sigma}\end{array}$ & فं & d. \\
\hline 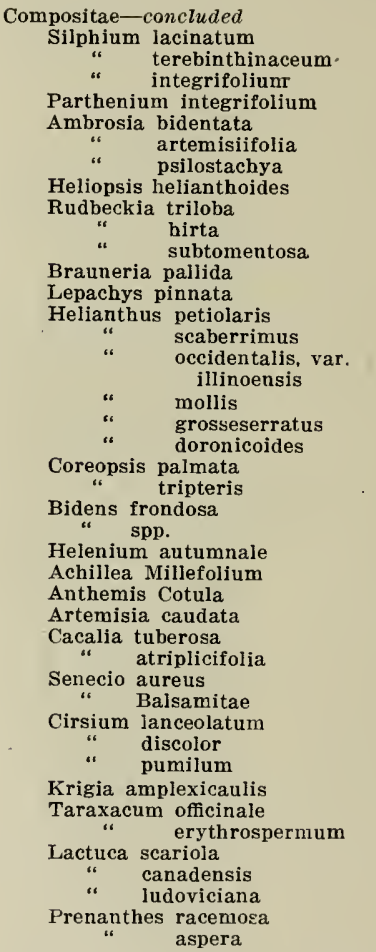 & & & $\grave{\dagger}$ & $\begin{array}{l}\dagger \\
\dagger \\
\dagger\end{array}$ & $\begin{array}{l}\dagger \\
\dagger \\
\vdots \\
\dagger\end{array}$ & $\begin{array}{l}t \\
\vdots \\
\dagger \\
t \\
\dagger \\
\dagger \\
\vdots \\
\vdots \\
\dagger\end{array}$ & $\begin{array}{l}\dagger \\
\dagger \\
\dagger\end{array}$ & $\dagger$ & $\begin{array}{l}\dagger \\
\dagger\end{array}$ & . \\
\hline
\end{tabular}




\section{Non-technical Summary}

The foregoing technical report is written, in the main, for trained botanists and agriculturists and needs no further summary. Since the prairie region of Illinois is the greatest natural asset of the state and, therefore, of considerable interest to the general public, it may not be amiss to end this report with a non-technical summary of its outstanding features.

The variations in the native fertility of the different soils of the state are a result mainly of the kinds of native plants that have grown upon these soils since the recession of the glaciers that formerly covered nearly the entire area of the state (map page 530 ). When the glaciers melted, the surface of the state was left covered with a deposit of clay, pulverized rock, and bowlders which the glaciers had picked up and carried southward from the Hudson and Labrador regions. The unequal deposition of this glacial drift left the state with a gently rolling topography. The depressions became shallow lakes, many of which were several square miles in area. Streams from the melting ice left rather large deposits of sand in some parts of the state. Thus the early postglacial soil, aside from these sand deposits, consisted of clay, pulverized rock, and bowlders, practically devoid of organic matter and of general uniformity throughout most of the state. The varying amounts of humus in these soils today are the results of the growth and decay of vegetation upon them during the postglacial period.

Botanists are reasonably certain that the first plants which grew upon the glacial drift were the same as those found growing today just south of the present glaciers in the north. The first zone of vegetation south of these glaciers is a tundra on which mosses, lichens, grasses, sedges, and low heath-like shrubs are the prominent plants; the second zone is the northern evergreen forest of spruce and fir on the uplands and bogs in many of the smaller lakes; the third zone is the deciduous hardwood forest with trees on the uplands and sedges in many of the shallow lakes.

As the glaciers receded from Illinois the tundra was replaced by the northern spruce-fir forest, and finally, the spruce-fir forest by the deciduous hardwood forest. This forest, however, did not cover all of the upland area of the state, a part of which was covered by tall grasse: characteristic of the prairie, cliefly tall bluestem (Andropogon furcatus). Only about one third of the state became forested in contrast to the much greater proportion of forest to prairie in Indiana and Ohio. There is evidence that the prairie on the upland areas originated during a postglacial dry period when the prairie extended farther eastward than at present. The shallow postglacial lakes did not become forested but supported a luxuriant growth of herbaceous water plants which decayed, but slowly. beneath the surface water and gradually filled the lakes. In this way enormous sloughs arose and a deep deposit of humus accumulated. The 
depth and area of these postglacial lakes are attested today by the depth and extent of the rich humus soils which accumulated in them. The deeper peat deposits in some parts of the state evidently had their origin in the postglacial bogs noted above.

As the postglacial lakes became filled and better drained through the decay of vegetation in them and partly by the vertical cutting of streams and the deposition of debris washed from the uplands, the pioneer water-plants died and were replaced by plants characteristic of the better-drained soils. The series of this succession of plants leading to the gradual filling of the sloughs may be seen today in areas little disturbed by man. At first the bulrushes are the most abundant and prominent plants accompanied by fewer individuals of many other water plants which are unable to become abundant in competition with the luxuriant growth of the bulrushes. The bulrushes, therefore, may be called the dominant plants at this stage of filling of the sloughs. A miniature bulrush slough is shown in Plate LIV. The bulrushes begin to die as the sloughs become drier through filling or drainage and are replaced by sedges which dominate during a second stage of deposition (Plate XLVIII). The sedges are followed by slough grass (Spartina Michauxiana. Plates XLIX, L). Sometimes the slough grass follows the bulrushes directly without an intervening sedge stage. At this stage the slonghs may become dry for a few months during summer, but are still too wet for cultivation. The slongh grass is followed in order by blue joint-grass (Calamagrostis canadensis, Plate LI), and tall Panicum (Panicum virgatum) or by. Panicum alone, which, in turn, is finally replaced by tall bluestem (Plates LXV-LXX). Tall bluestem remains as the dominant grass of the true prairie. The early settlers found most of the bluestem prairie dry enough for cultivation. All gradations in the filling of the sloughs were seen by the early settlers. Most of the prairie area on the older glaciated part of the state south of the latitude of Mattoon had become covered by tall bluestem, but a large part of the prairie region in the younger glaciated area north of this latitude was not dry enough for tall bluestem and abounded in numerous sloughs of bulrush and slough grass. These drained sloughs and prairies with their deep deposits of humus are now the most productive lands of the state.

Where the upland clay soils become covered with a prairie vegetation instead of a forest, the first abundant grass to appear upon them is short bluestem (Andropogon scoparius). This grass, in time, becomes crowded out and is replaced by the tall bluestem.

Some of the sand deposits of the state became forested, but a large part of them became covered with a prairie vegetation. The first plants that grew upon the dry moving sand-dunes were not plants of the prairie, but short grasses more characteristic of the plants found upon the sand hills of Kansas and Nebraska (Plate LXXI). These pioneer plants, in time, developed a carpet of vegetation sufficient to hold the sand against the force of the wind. Through their death and decay 
humus was added to the sand, increasing both the stability and waterholding capacity of the sandy soils. This made conditions favorable for the growth of plants characteristic of the prairie. Short bluestem first became abundant and crowded out most of the pioneer plants (Plates LXXII, LXXIV). With further increase of humus, stability, and

- water content of the sandy soils tall bluestem came in and crowded out the short bluestem (Plate LXXV). This succession of grasses, leading ultimately to tall bluestem on the sand deposits, was not completed on all the sand areas of the state when the first settlers arrived. All gradations from the pioneer to the climax could be found.

Starting with the pioneer soil-conditions left by the melting glaciers, the accumulation of organic matter from vegetation and the work of erosion have been gradually changing the topography, water content, and composition of the soils of the state. The change in water content of the soil was the most potent factor underlying the changes in prairie vegetation discussed above. With a decrease in water content of the areas covered by sloughs and an increase in the water content of clay slopes and sand accompanying the increase in humus and stability of the soil, more and more of the prairie area became covered by tall bluestem. This grass was the most abundant and prominent prairie plant on all the well-drained and sufficiently moist prairie areas of the state. In all the successions of prairie plants accompanying the filling and draining of sloughs, the wearing down of clay slopes, and the stabilization of sandy soils, the ultimate vegetation of the prairie is dominated by tall bluestem. This means that tall bluestem is the climax grass of the prairies of Illinois. It will remain the dominant prairie plant under natural conditions unless the water content of the soil is again seriously changed. Where the turf is broken by eroding heads of ravines it may be succeeded by a forest. A glance at Dr. Brendel's map (page 526) shows that much of the forest area of the state has developed in this way and is generally distributed along all the creeks and rivers.

None of the pictures accompanying this report give an adequate conception of the former bluestem prairies. This grass forms a close sod and under good growing condition may reach the height of 10-12 feet. The early settlers say that they were unable to locate cattle on the prairie except by climbing some elevation and watching for the waving of the tall grass as the cattle walked through it. Its growth was sufficiently dense to crowd out most of the other prairie plants, among the most prominent of which were plants of the mint, bean, and sunflower families. On eroding clay slopes and along forest borders the yellow, blue, and white flowers of these coarse herbs became conspicuous in late summer and autumn. A glance at Plate L may give some impression of the rank growth of the prairie grasses.

The humus accumulated on our prairie soils does not supply food to our crop plants. Like all green plants they make their food chiefly out of water and carbon dioxide. In the manufacture of carbohydrates 
and fats no other raw material is used, but in the manufacture of protein a supply of nitrates, sulphates, and a small amount of phosphates are also used. Decaying organic matter, however, does greatly increase the fertility of soils through its favorable effect on the water content of the soil, ease of root penetration, soil aeration, and soil temperature, checking the leaching of minerals, and being a source of carbohydrate supply for some of the nitrogen-fixing bacteria and fungi in the soil.

The decay of forest vegetation also adds humus to the soil, but not so rapidly nor in as great amounts as is added by the decay of prairie plants. The glacial drift that has been forested a considerable part of the time since the recession of the glaciers has much less humus accumulated in it than is found on the drift covered by a prairie vegetation. Soil surveys conducted by the Illinois Experiment Station show that the forested soils have only from 25-50 per cent. as much organic matter in them as is found in the adjoining prairie soils. This is a result of the fact that most of the forest vegetation accumulates and mostly decays on the surface of the soil, while the numerous roots and root-stocks of the prairie vegetation accumulate and decay more slowly beneath the surface of the soil. This difference, of course, does not apply to flood-plain forests, where deposition during overflows is an important factor in soil fertility, nor to the occasional small forest areas that have developed from swamps in which the slowly decaying organic matter accumulates under water during the greater part of the year. The greater amount of humus accumulated in the prairie soils increases their fertility over that of the forest soils by increasing the check on the leaching of minerals, such as calcium, and by increasing the other favorable effects of humus noted above. This explains why farms formerly forested decrease in yield from year to year more rapidly than farms on adjacent prairie soils, both of which have had the same history except for the different kinds of native plants that have grown upon them. Where erosion follows deforestation the cleared lands become unprofitable for cultivation within a few years. Such areas should be kept in permanent forests.

It is evident, therefore, that the variations in native fertility of the different soils of the state are a result, mainly, of the kinds of native plants that have grown upon them and the conditions under which these plants grew since glacial times. Prairie and forest, alike, developed on glacial till. Prairie vegetation has added more humus and brought about a bigger change in the surface soil than forest. Their subsoils are alike. It is obvious, therefore, that the cause of the original prairies or forests in Illinois is not to be found in the different compositions of the soils of today. Aside from climatic conditions, the water content of the soil and not the kind of soil has been the most important factor in determining what kind of native plants grew upon any given area of the state. Under the present conditions of drainage, whenever the prairie turf is broken by erosion or other means a forest vegetation may 
develop, but this fact has no bearing upon the explanations of causes of the original prairies and forests of the state.

The progress of civilization during the last century has not only destroyed nearly all of the native prairies of the state but, likewise, some of the conditions that gave rise to them. Grazing, drainage, cultivation, and stream pollution have all been destructive to the native prairie flora. Cultivation has destroyed the prairie plants except along fences between the farms, while grazing has destroyed even these last remnants not reached by the plow. Intensive grazing accompanied by the introduction of blue grass and red top destroyed practically all of the native prairie plants on the farms not cultivated. The bluestem prairies became bluegrass pastures, and where drainage accompanied grazing the native plants of the sloughs were also replaced by blue grass. In areas too wet for blue grass, red top became abundant, while in still wetter areas sedges and rushes prevailed. The bulrushes were mostly killed by the tramping of cattle, and cattails became abundant in the undrained sloughs. Grazing on the sand prairies destroyed the bluestem, and blue grass became abundant, giving rise to blue-grass pastures on sand. But where the sand areas were still too dry for the bluestems, grazing has increased the number of blowouts in the sparser vegetation of plains grasses. Some of the bluestem prairies on sand were cultivated instead of pastured. This has led (1) to the destruction of much of the humus accumulated for centuries by the decay of the native grasses, and ( 2$)$ to the exposure of loose sand to wind action through the destruction of the prairie turf. As a result, blowouts and sand dunes become increasingly abundant, and the farms must shortly be abandoned. Carefully conducted experiments would undoubtedly result in the discovery of more profitable methods of dealing with these sand areas.

The changes brought about by drainage are somewhat too complicated to be discussed in detail in this summary. Artificial drainage has lowered the water-table several feet and drained most of the sloughs. This has led to all degrees of destruction of the natural grasses of the sloughs and made conditions favorable for the migration into them of plants characteristic of better-drained soils. Artificial drainage led to a sudden disturbance of the balance that obtained under natural conditions, and plants that reproduce most readily had a chance to become prominent. As a result, many plants not prominent on the natural prairies became temporarily abundant on the newly drained areas. This condition is well represented on the railway rights-of-way today. Artificial drainage is also favorable to the development of forests on the wet prairies.

The effect of the pollution of streams and prairie ponds received little attention in this survey. It appears to have been destructive to bulrushes and favorable to the growth of cattails. Its chief economic effect is to be found in the destruction of algae, the main source of the food of fishes. 
This summary would not be complete without a word on the causes of the prairie. No other question of the prairie has been discussed so frequently or widely, and the answers to the question are as widely variable as their authors. This is a result, largely, of the various authors emphasizing local factors which would not apply to the prairies as a whole, or emphasizing only one of several factors which operating together may explain the prairies, but when considered separately fall far short of an adequate explanation. For instance, prairie fires, grazing, and the character of the soil are factors that may affect the local distribution of prairie and forest at their borders, but become insignificant in any attempt to explain the prairies as a whole. In some cases they have been reported as favorable to forest, in others as favorable to prairie. As a matter of fact, prairie fires and grazing are an effect rather than a cause of the prairies. As shown above, this may be true also of the prairie soils in so far as they differ from forest soils. On the other hand, temperature, wind, humidity, rainfall, and topography were all important factors in causing the treelessness of the prairies, but no one of these five factors considered alone will explain the prairies.

Omitting topography for the moment, it is possible to analyze the effect of the remaining four factors in terms of only two factors. Temperature, wind, and humidity all affect the rate of evaporation of water, and it is in this way that they operate in affecting the development of forest and prairie. They may be dealt with as one factor, namely, evaporation. IVe have to consider, therefore, only the factors, evaporation and rainfall. Both rainfall and evaporation are measured in inches per year by the Weather Bureaus. The amount of evaporation is obtained by exposing standard open vessels of water and keeping the record of water loss each day. At the end of the year this may be calculated to terms of inches of water lost by evaporation.

If the number of inches of annual rainfall (precipitation in general) is divided by the number of inches of annual evaporation, these two factors may be expressed as a single factor, namely, the per cent. or ratio of rainfall to evaporation. When the rainfall-evaporation ratios obtained at various places in the United States are plotted on a map, we are able to determine the combined effects of the four climatic factors-temperature, wind, humidity, and rainfall-upon the distribution of the natural vegetation. (See map on page 524.) The region of the United States in which the ratio of rainfall to evaporation is between 60 and 80 per cent. coincides very closely with the prairie region. In general, where the ratio is less than 60 per cent. plains or deserts result; where it is more than 80 per cent. forests are found. Since the annual distribution of rainfall is also important, these figures are not absolute for all localities. Hence, the chief cause of the prairie lies in the combined action of the four climatic factors named above through their effect upon the water relations of the plants concerned.

Topography may effect the distribution of prairies through its effect on some one or more of the climatic factors, as in the exposure 
or protection of slopes from prevailing winds or the direct rays of the sun. In Illinois, topography was an important factor in the origin of prairies that developed from postglacial lakes through its effect on the water content of the soil. Prairies also developed on some of the welldrained upland soil. Forests were more common on the higher moraines, flood-plains, and river bluffs.

To-sum up, climatic factors are of primary importance in determining the general boundaries of distribution of the prairies, while the ever changing topography and water content of the soil are important in determining where sloughs, prairies, or forests will develop withirf these boundaries. The effect of these soil factors is more prominent near the boundaries of the prairie region than near its center of distribution where we find prairies growing on the greatest range of soil conditions.

Where a prairie or swamp vegetation is once established still another factor becomes important in kceping out the forest even after the swamps have become well drained, namely, the ability of the tall grasses to outgrow and over-shade the seedlings of forest trees. In the case of the drier prairies the grasses with their well-established root system have a monopoly of the water supply in the soil, and may prevent the development of seedlings of forest trees.

Forest invasion of prairies however does occur. It may follow the destruction of the prairie turf by erosion or it may precede erosion. Forest invasion on non-eroded prairie soils in Illinois is more extensive on the older glaciated regions of the state than on the younger glaciated regions. On the Wisconsin glaciated region this invasion is nost common on the slightly elevated prairies, but there are natural groves of forest on some of the non-eroded black prairie soils.

The Ohio State University,

Columbus, Ohio. 


\section{LITERATURE CITED}

Barrows, H. H.

(1) 1910. Geography of the Middle Illinois Valley. Bul. Ill. Geol. Surv., No. 15.

Cannon, W. A., and Free, E. E.

(2) 191\% The ecological significance of soil aeration. Science, new ser., 45 (No. 1156): 178-180.

\section{County Soil Reports}

(3) Nos. 1-14, Univ. Ill. Agr. Exper. Station.

Cowles, H. C.

(4) 1899. The ecological relations of the vegetation of the sand dunes of Lake Michigan. Bot. Gaz. 27: 95-177, 16 $\check{\imath}-202$, 281-308, 361-391.

(5) 1900. Physiographic ecology of Chicago and vicinity. Bot. Gaz. 31 : $73-108,145-182$.

Gates, F. C.

(6) 1912. The vegetation of the beach area in northeastern Illinois and southeastern Wisconsin. Bul. Ill. State Lab. Nat. Hist. 9 : 255-372.

Gerhard, Frederic

(7) $185 \%$. Illinois as it is, p. 238-247, 270-278.

Gleason, Henry Allan

(8) 1909. Some unsolved problems of the prairies. Bul. Tor. Bot. Club, 36: 265-271.

(9) 1910 . The vegetation of the inland sand deposits of Illinois. Bul. Ill. State Lab. Nat. Hist. 9: 23-174.

(10) 1912. A comparison of the rates of evaporation in certain associations in central Illinois. Bot. Gaz. 53: 478-491.

Hart, Charles A., and Gleason, H. A.

(11) $190 \%$. On the biology of the sand areas of Illinois. Bul. Ill.

Harvey, E. M. State Lab. Nat. Hist., 7: 137-272.

(12) 1913. Evaporation and soil moisture on the prairies of Illinois. Hayden, Ada Trans. Ill. Acad. Sci., 6: 92-99.

(13) 1919. The ecological foliar anatomy of some plants of a prairic province in central Iowa. Amer. Jour. Bot. 6: $69-85$.

(14) 1919. The ecologic subterranean anatomy of some plants of a prairie province in central Iowa. Amer. Jour. Bot. 6: $8 \%-104$.

Hopkins, Cyril G., Mosier, J. G., and Baur, F. C.

(15) 1916. Summary of Illinois soil investigations. Bul. Univ. Ill. Agr. Exper. Sta., No. 193. 
Hopkins, Cyril G., Readhimer, J. E., and Fisher, O. S.

(16) 1912. Peaty swamp lands; sand and "alkali" soils. Bul. Univ.

Leverett, F. Ill. Agr. Exper. Sta. No. 15\%.

(17) $189 \%$. The Pleistocene features and deposits of the Chicago area. Bul. II, Geol. and Nat. Hist. Surv., Chicago Acad. Sci.

(18) 1899. The Illinois glacial lobe. U. S. Geol. Surv., Vol. 38. Mosher, Edna

(19) 1918. The grasses of Illinois. Bul. Univ. Ill. Agr. Exper. Sta. No. 205.

Salisbury, Rollin D., and Alden, W. C.

(20) 1899. The geography of Chicago and its environs. Bul. Geogr. Sayre, J. D. Soc. Chicago, No. 1.

(21) 1920 . The relation of hairy leaf coverings to the resistance of Schaffner, John $\mathrm{H}$. leaves to transpiration. Ohio Jour. Sci. $20: 55-86$.

(22) 1913. The characteristic plants of a typical prairie. The Ohio Sherff, Earl E. Naturalist, 13: 65-69.

(23) 1913. Vegetation of Skokie Marsh. Bul. State Lab. Nat. Hist. Shimek, B. 9: $5 \% 5-614$.

(24) 1911. The prairies. Bul. Lab. Nat. Hist., State Univ. Iowa, Transeau, E. N. 6: No. 1 .

(25) 1903. On the geographical distribution and ecological relations of the bog-plant societies of northern North America. Bot. Gaz. 36: 401-120.

(26) 1905. Forest centers of Eastern America. Amer. Nat. 39 : $875-889$.

Vestal, Arthur G.

(2\%) 1913. An associational stndy of the Illinois sand prairies. Bul. Ill. State Lab. Nat. Hist. 10: 1-96.

(28) 1914. A black-soil prairie station in northeastern Illinois. Bul. Tor. Bot. Club, 41: 351 .

Waller, Adolph E.

(29) 1918. Crop centers of the United States. Jour. Amer. Soc. Agron. 10: 49-83.

(30) 1918. The grasses. Correspondence Courses in Agriculture, Course VII, Lesson V. Extension Publications of the Ohio State University.

(31) 1921. The relation of plant successions to crop production. The Ohio University Publications, Vol. 25, No. 9. 


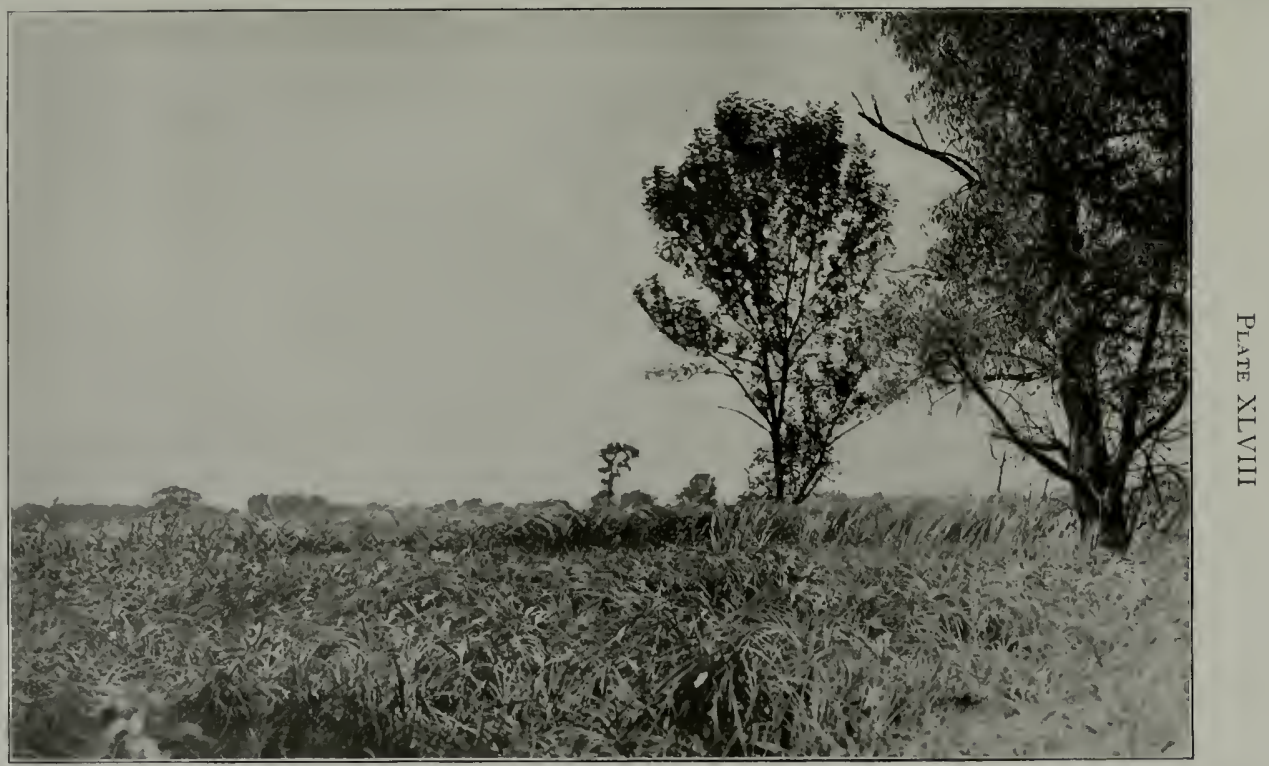

Carex vestraria association in foreground, Spartina Michan iane association in iackground. Flood-plain. Savanna, 111. 


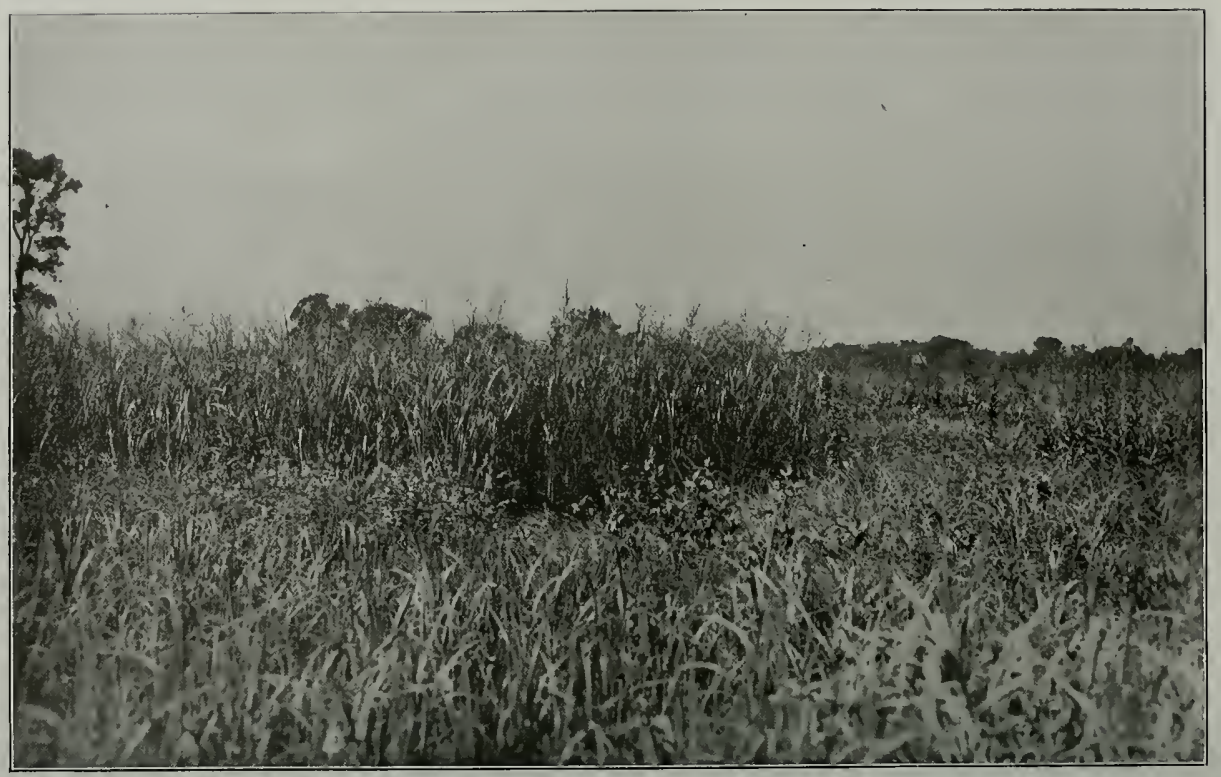

5
5
5
0
$x$

Same as Plate XLVII, a few weeks later. 


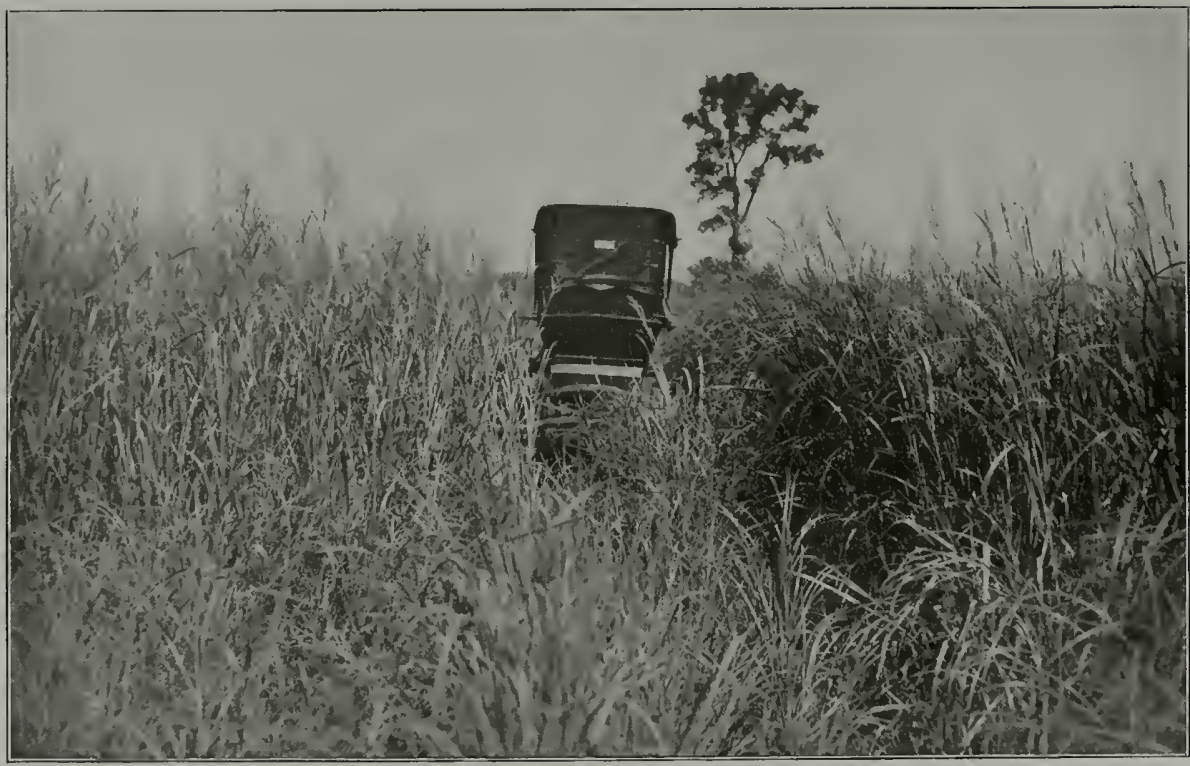

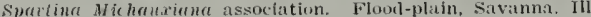




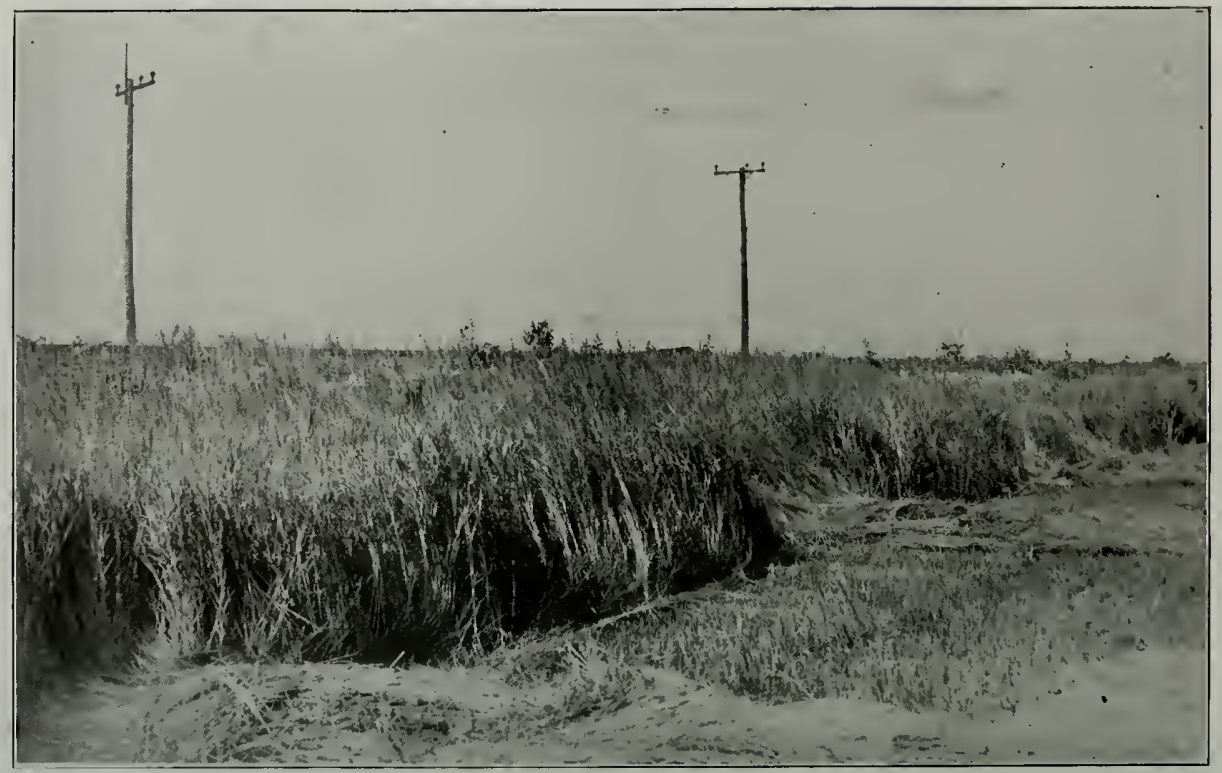

5

Calcmagrostis canadensis association on the Chicago prairie. Luxuriant growth is indicated by proximity of windrows. 


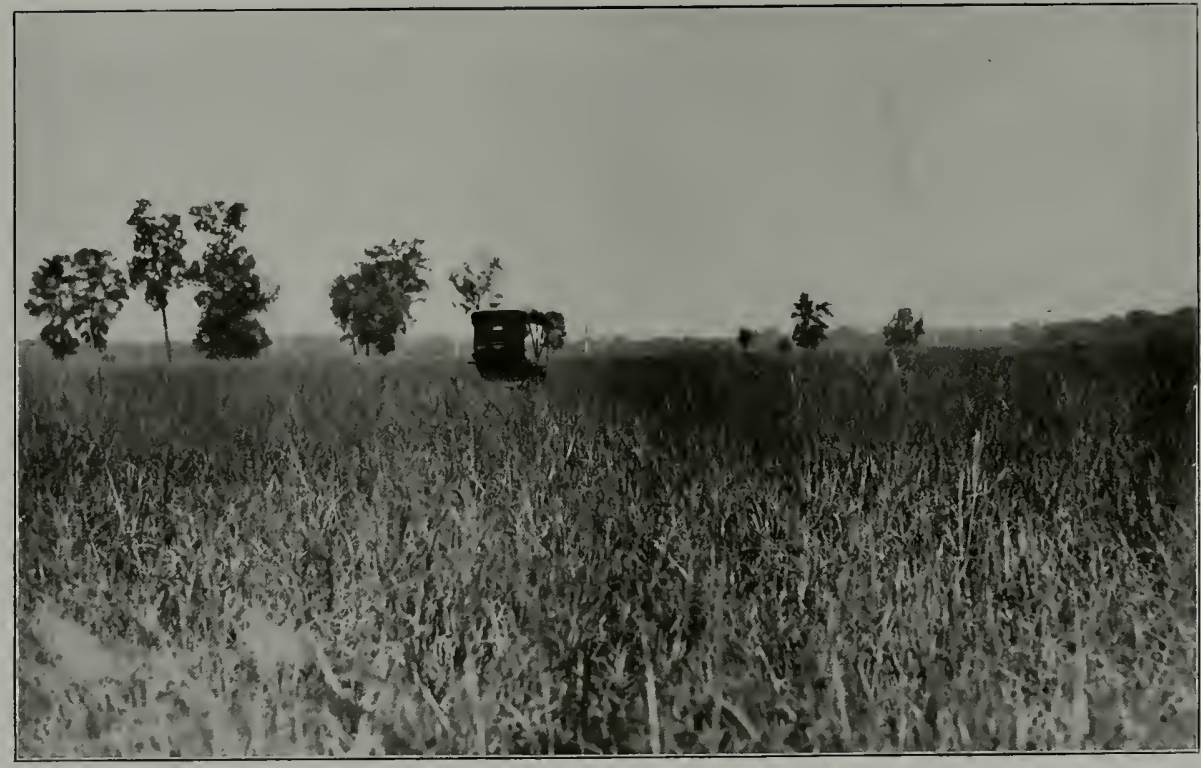




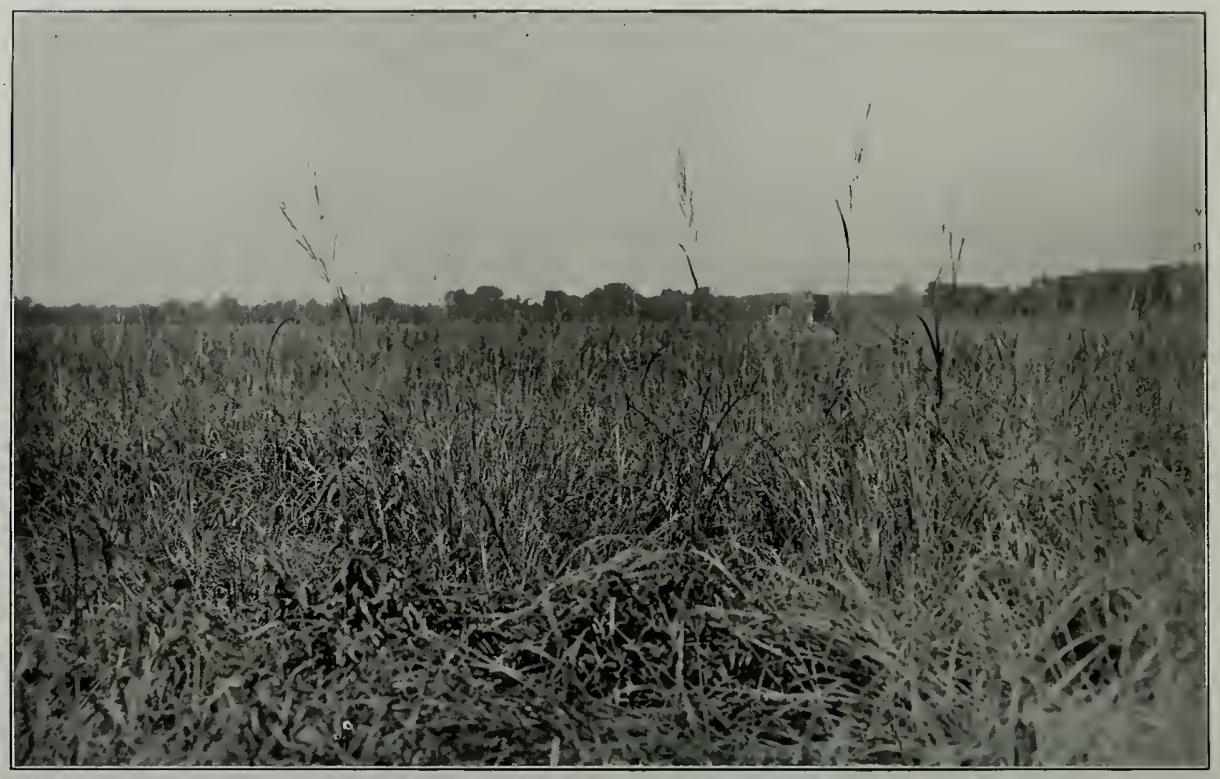

点

Andropogon furcatus in background. Some Spartina remaining in the narrow Panicum virgatum association in the foreground. Flood-piain, Savanna, Ill. 


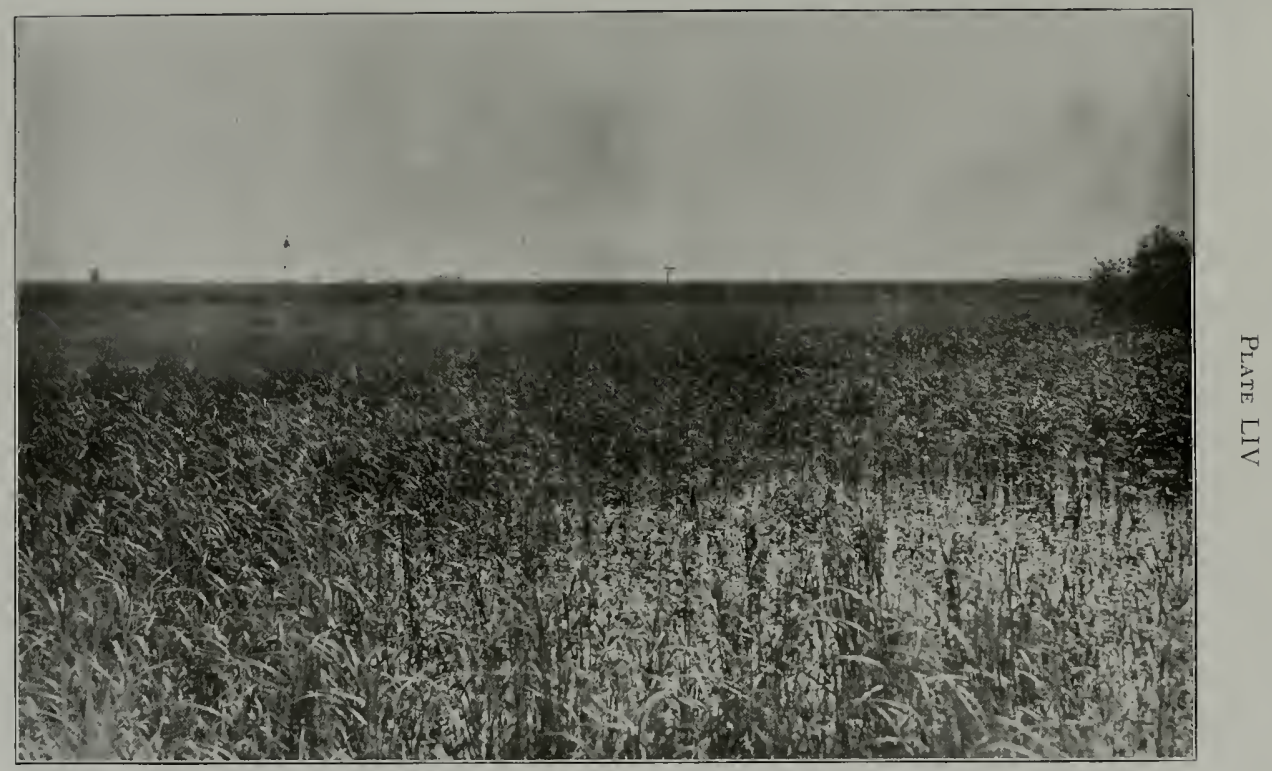

srivpus fuviatilis association in a small prairie pond at Chicago Lawn. See diagram, Figure 3, page 537 


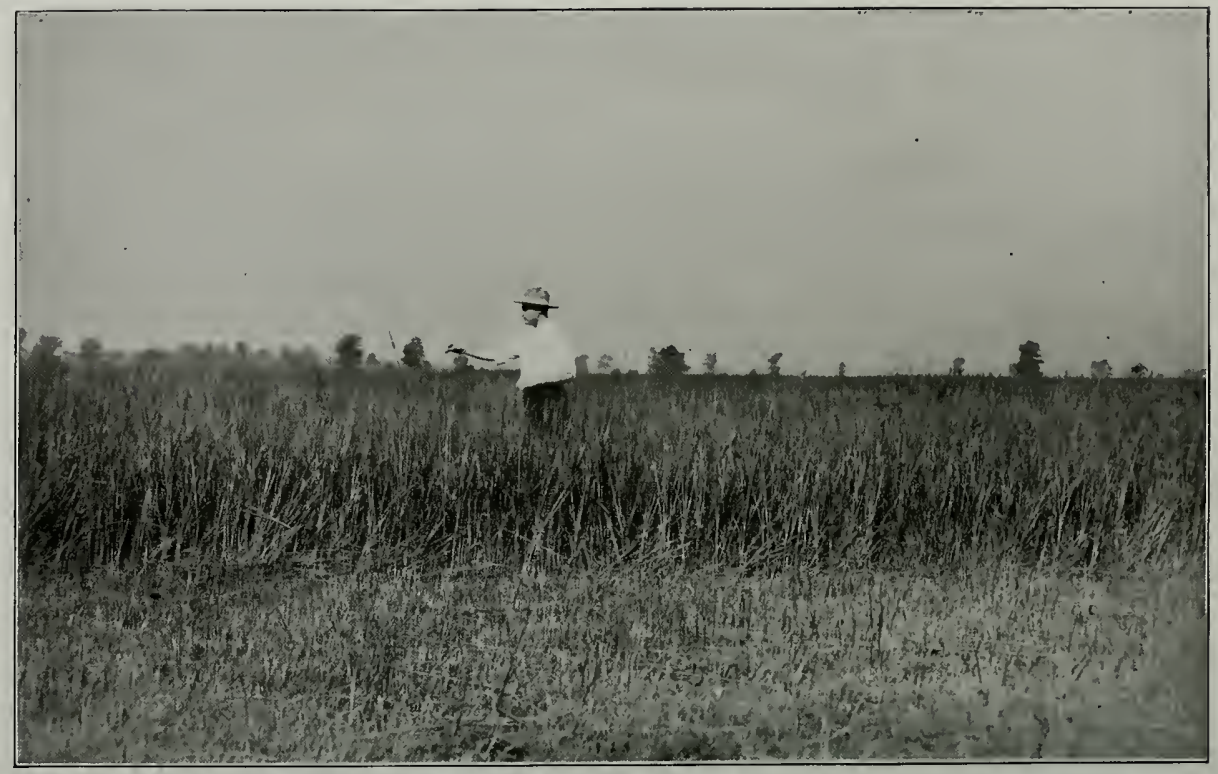




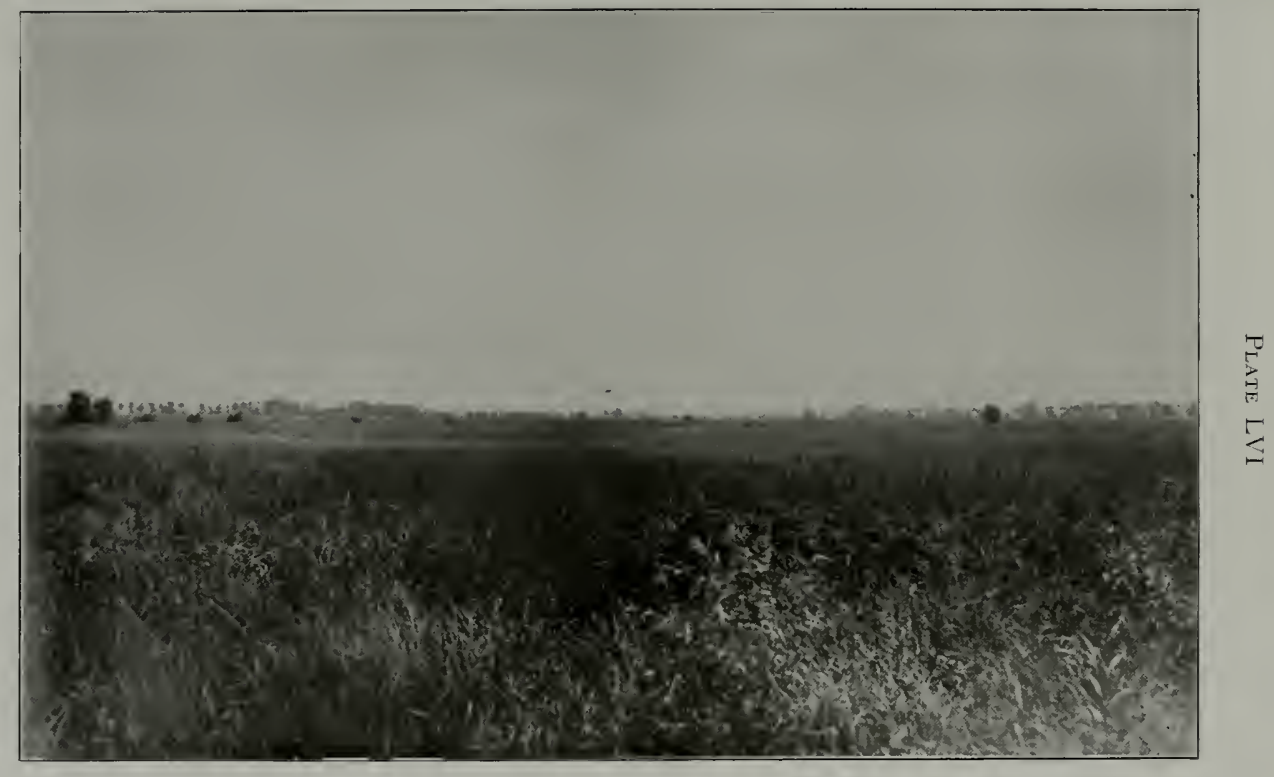

General view of the Chicago prairie south of Oak Ridge. Trees on the Calumet beach in background. 


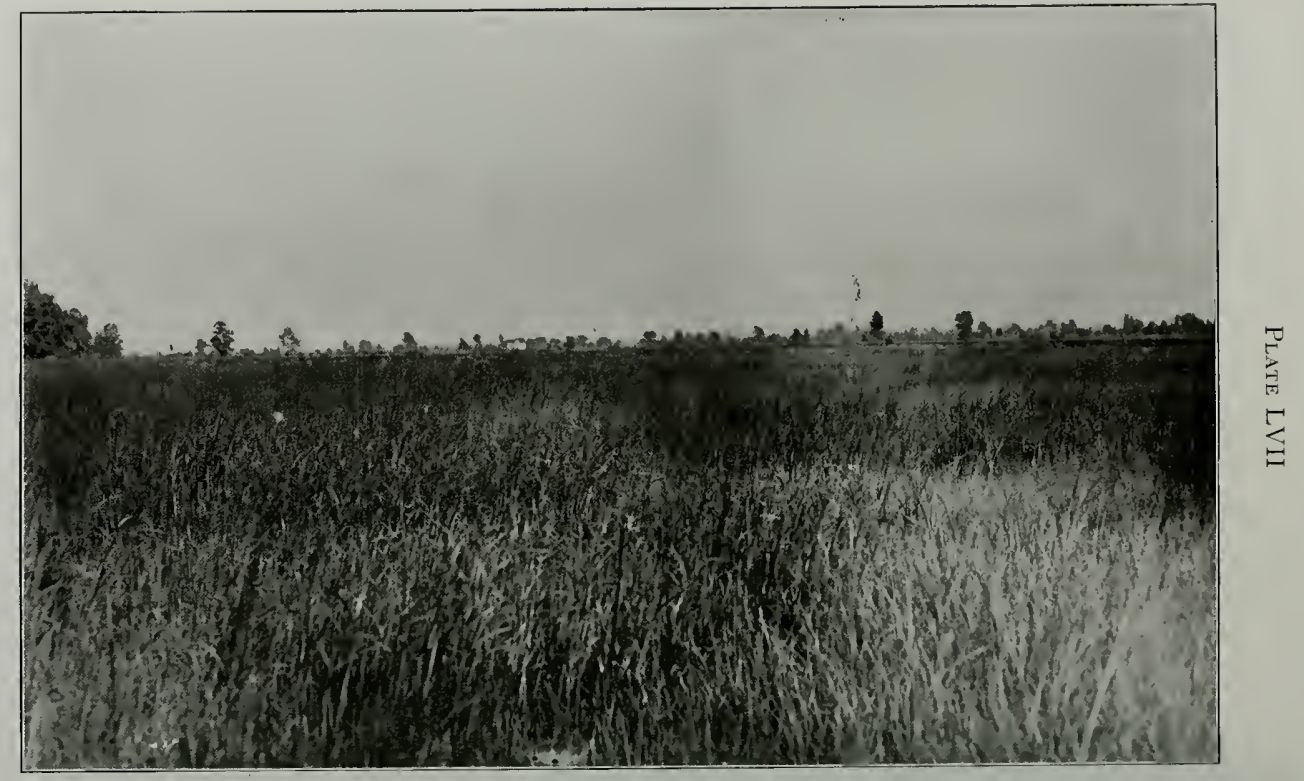

Panicum virgatum association. Chicago prairie. Trees along artificial drainage ditches. 



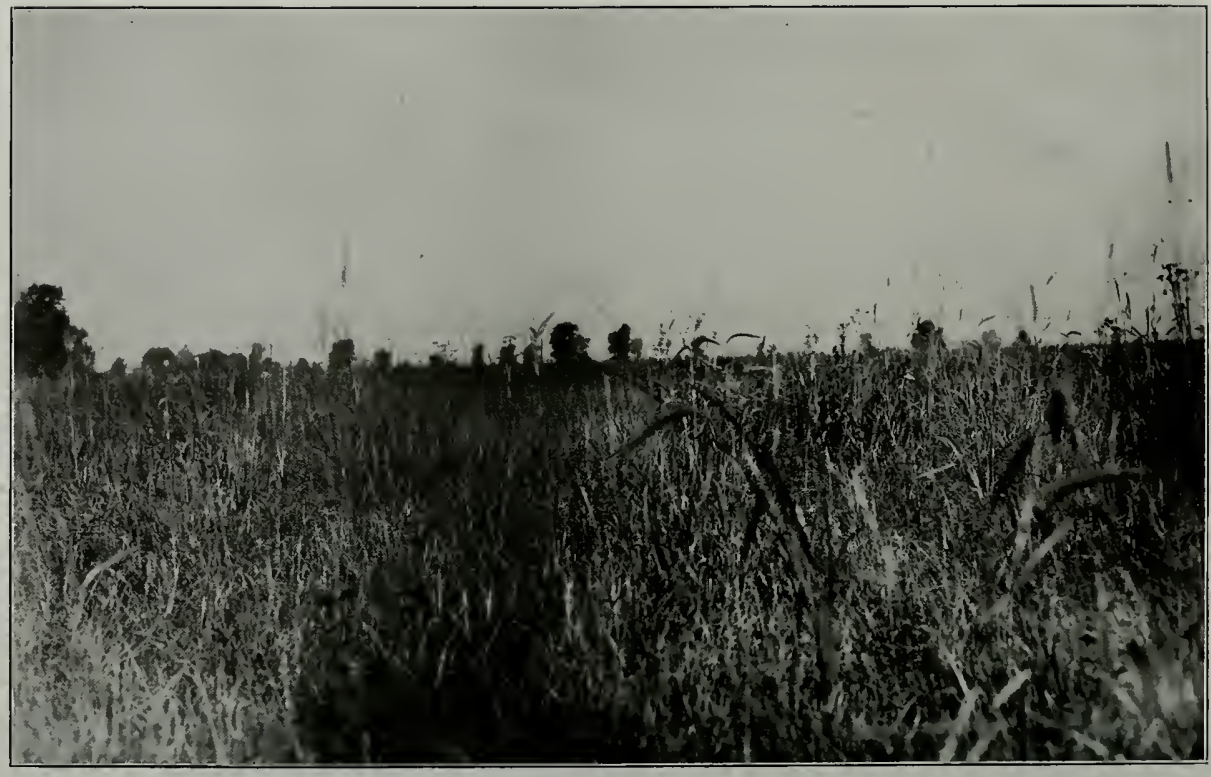

F

Andropogon furcatus coming into the Panicum virgatum association shown in Plate LVIII. 


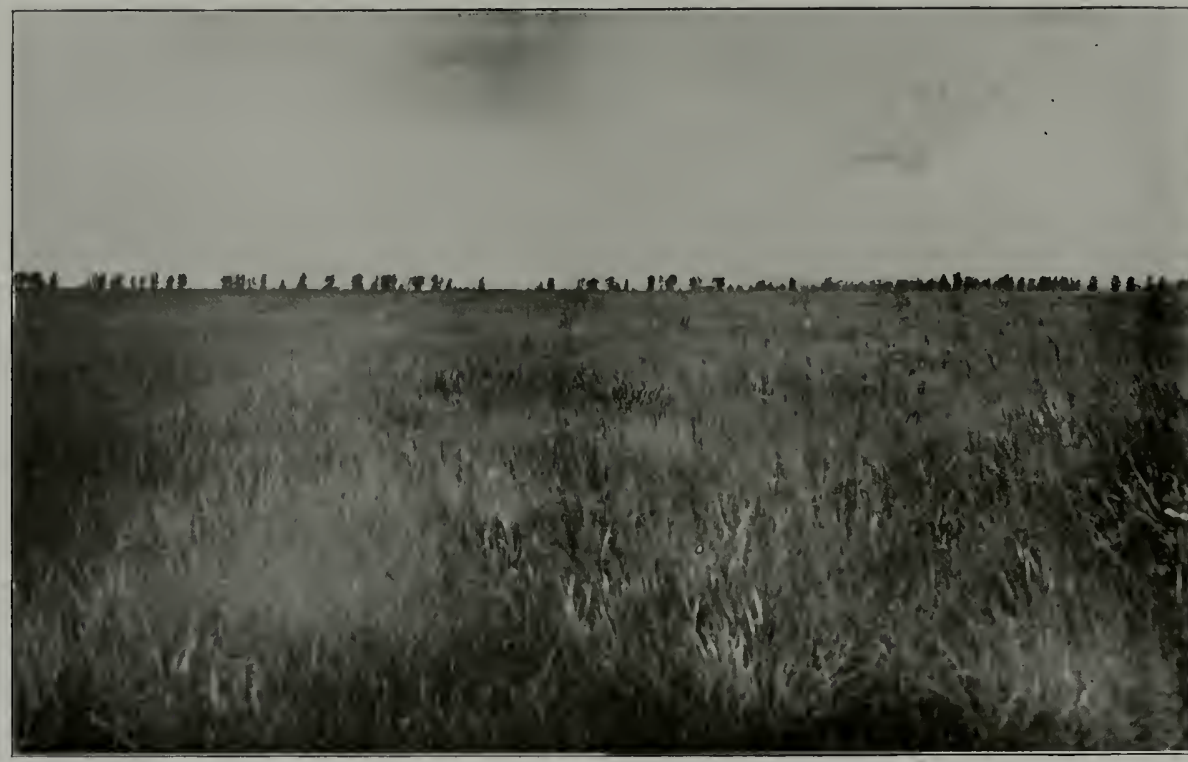

Agrostis alba (1lght color) in Panicum virgatum association. Chicago prairie. 


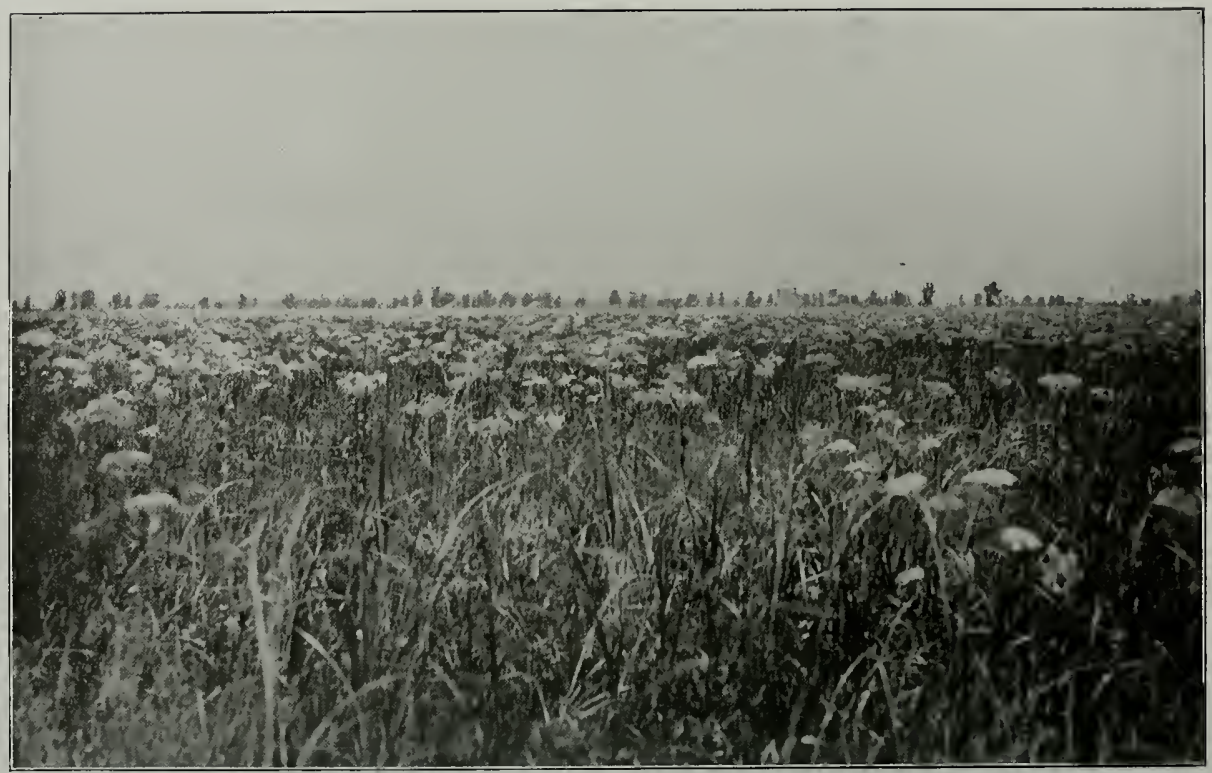

Cacalu tuberosa in Spartina association. Chicago prairie. 


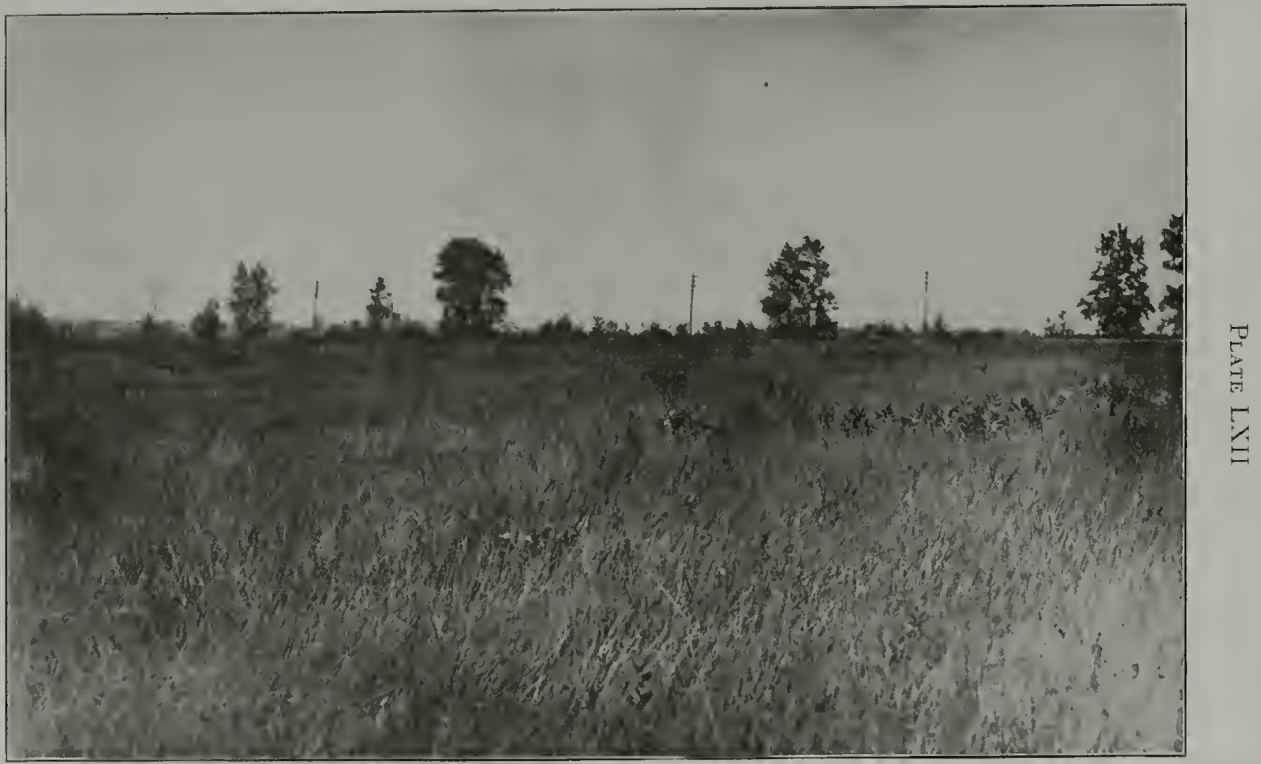

silphium luciniatum in calamagrostis association. Chicago prairie, 


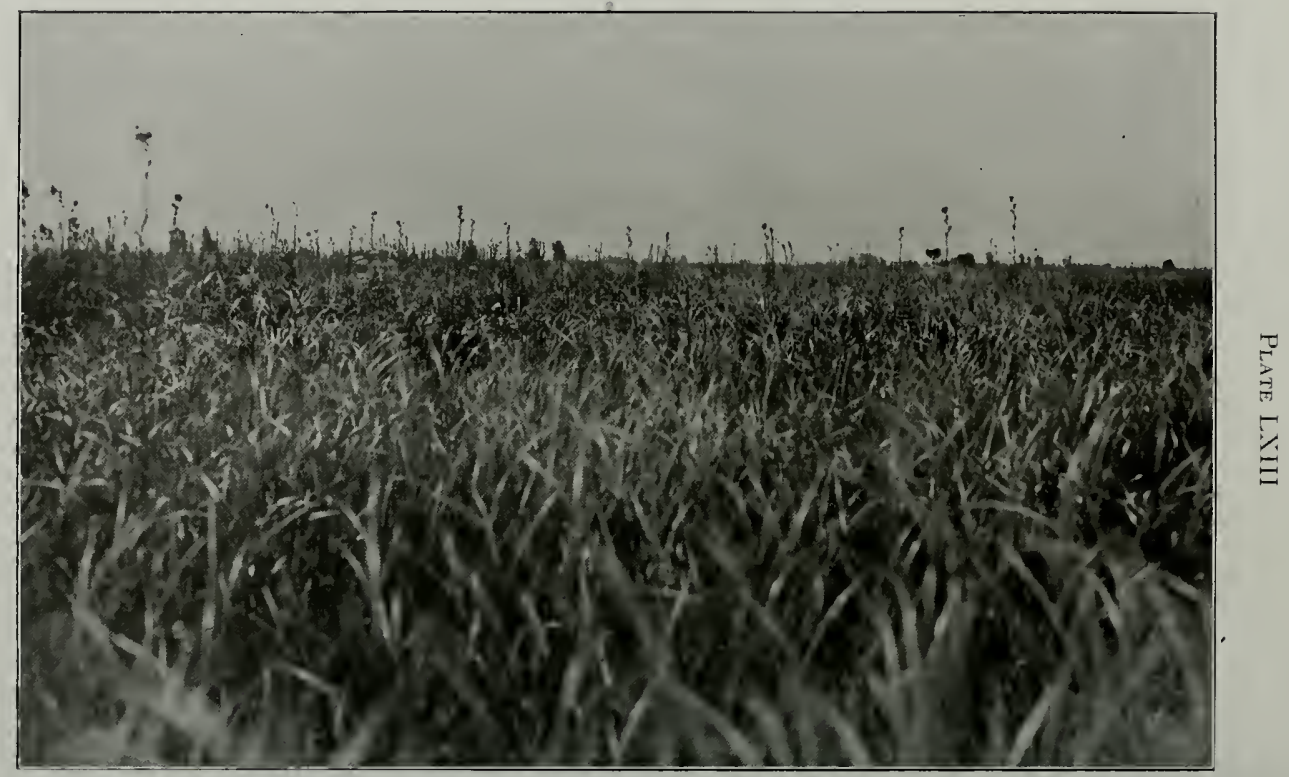

Silphium laciniatum in Spartina association. Chicago prairie. 


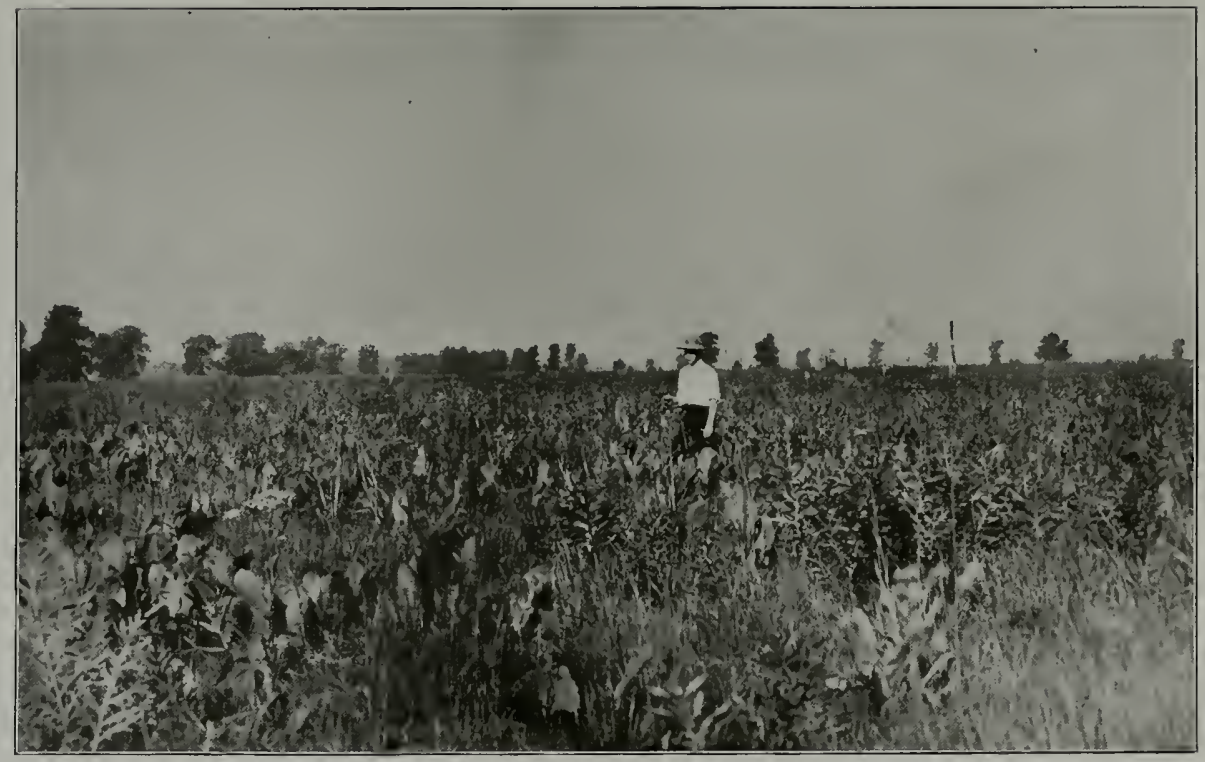

年

Silphium lacinatum and s. tercbiuthinaceum with Andropogon and Poa. Chicago prairie. 


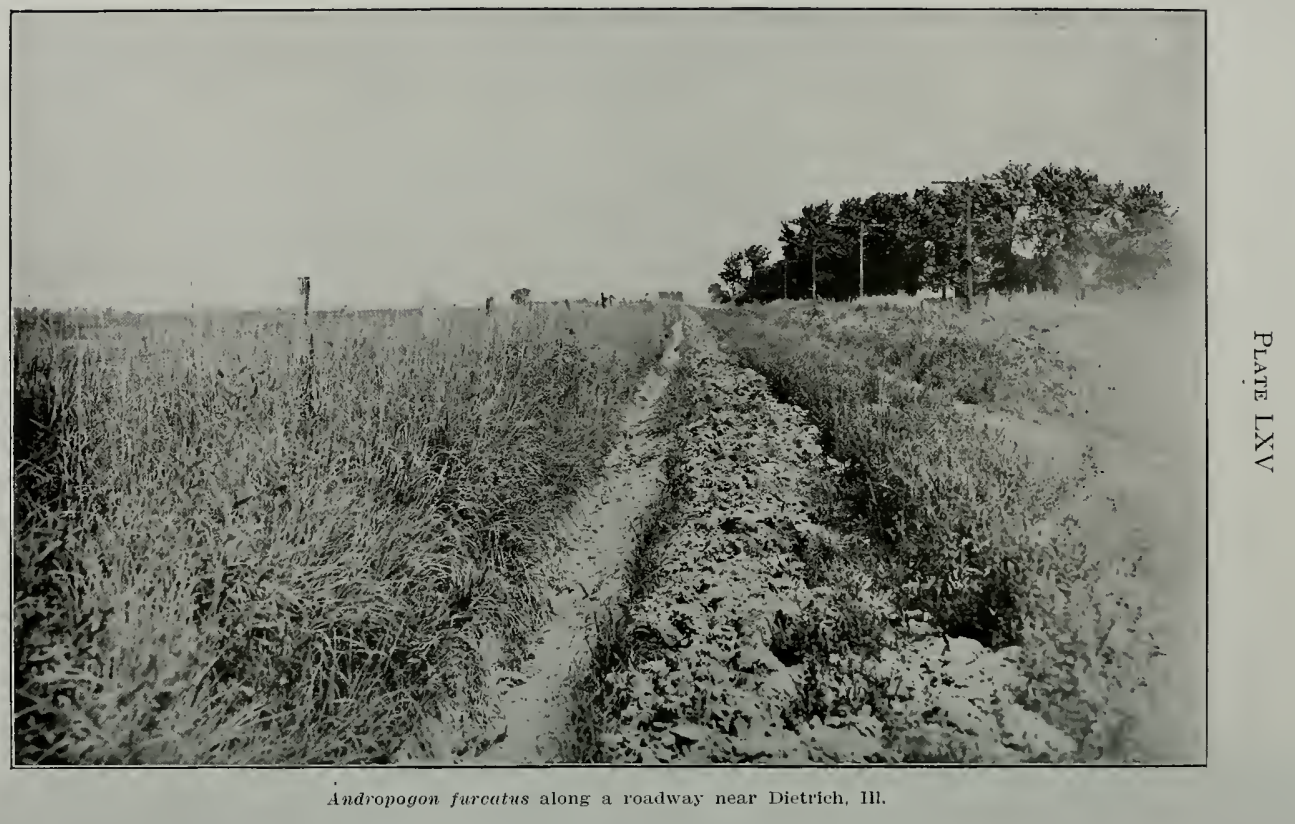




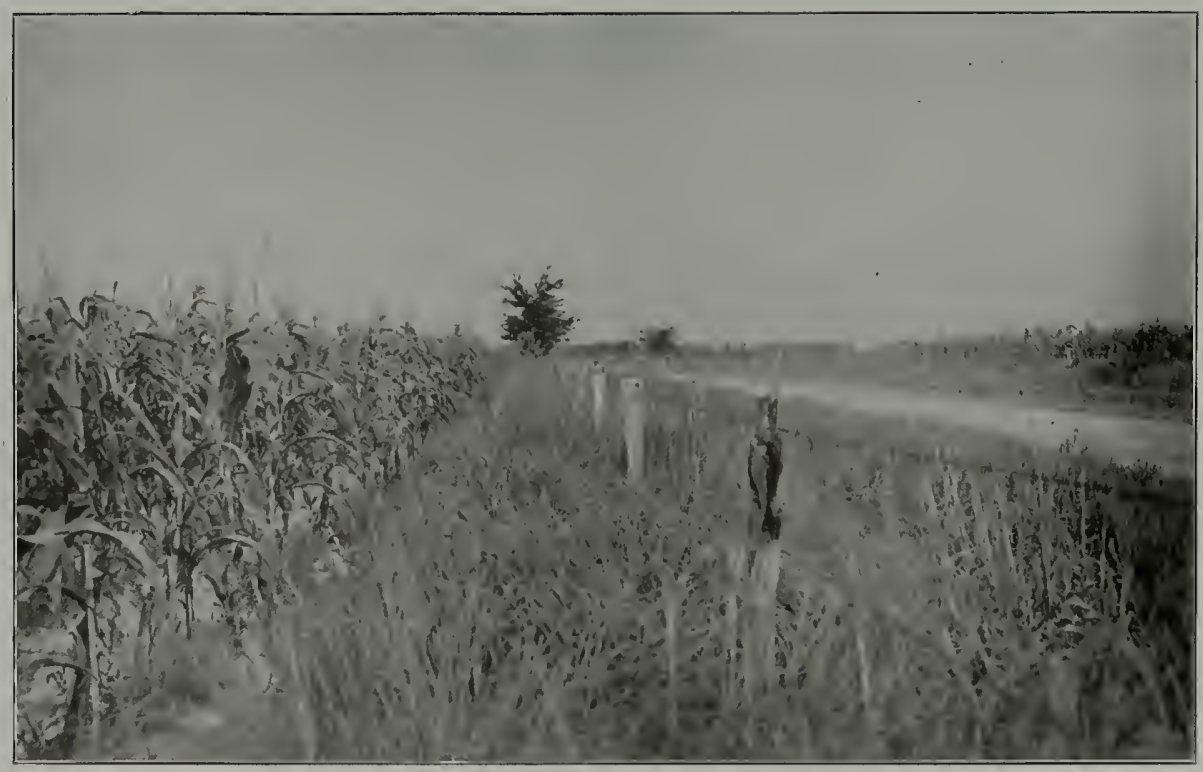

告

Andropogon furcetus along a roadway near wheeler, 111. 


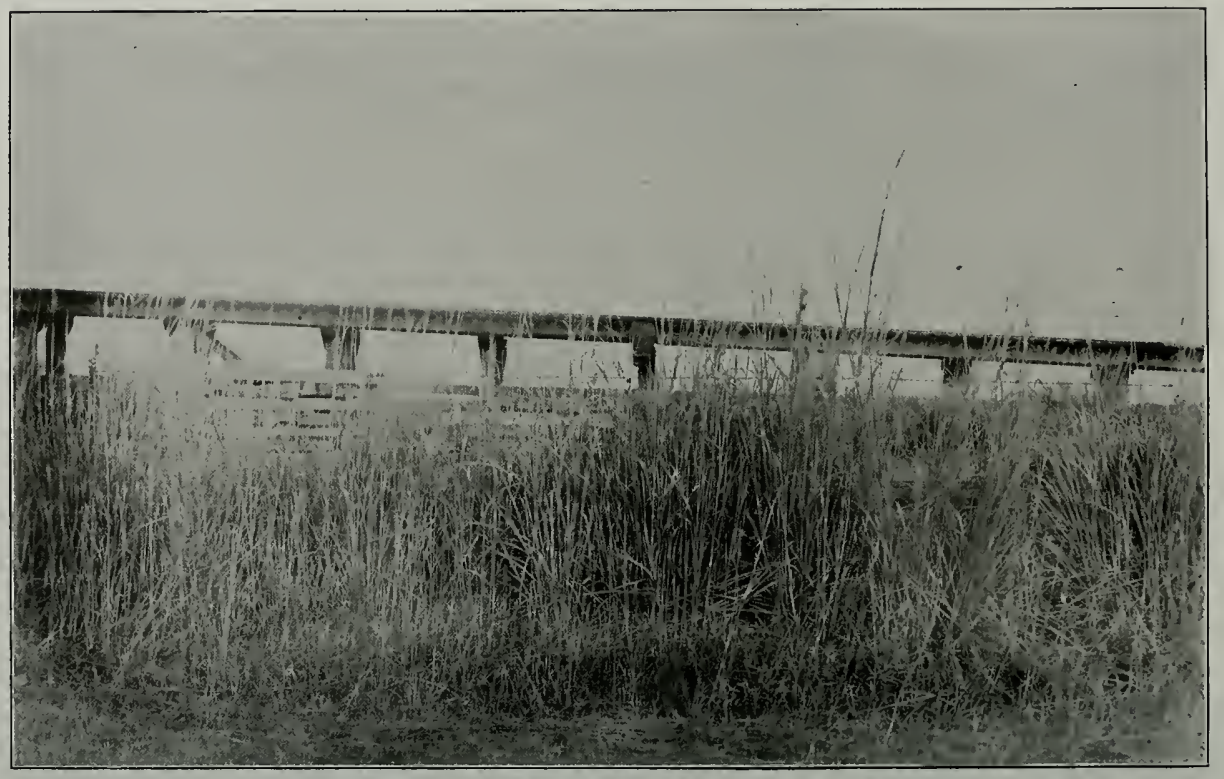

Andropogon furcatus near flowerlng stage. This strip of grass is about ten inches wide, and illustrates the dense growth and height of the tall bluestem. Effingham, Ill. 



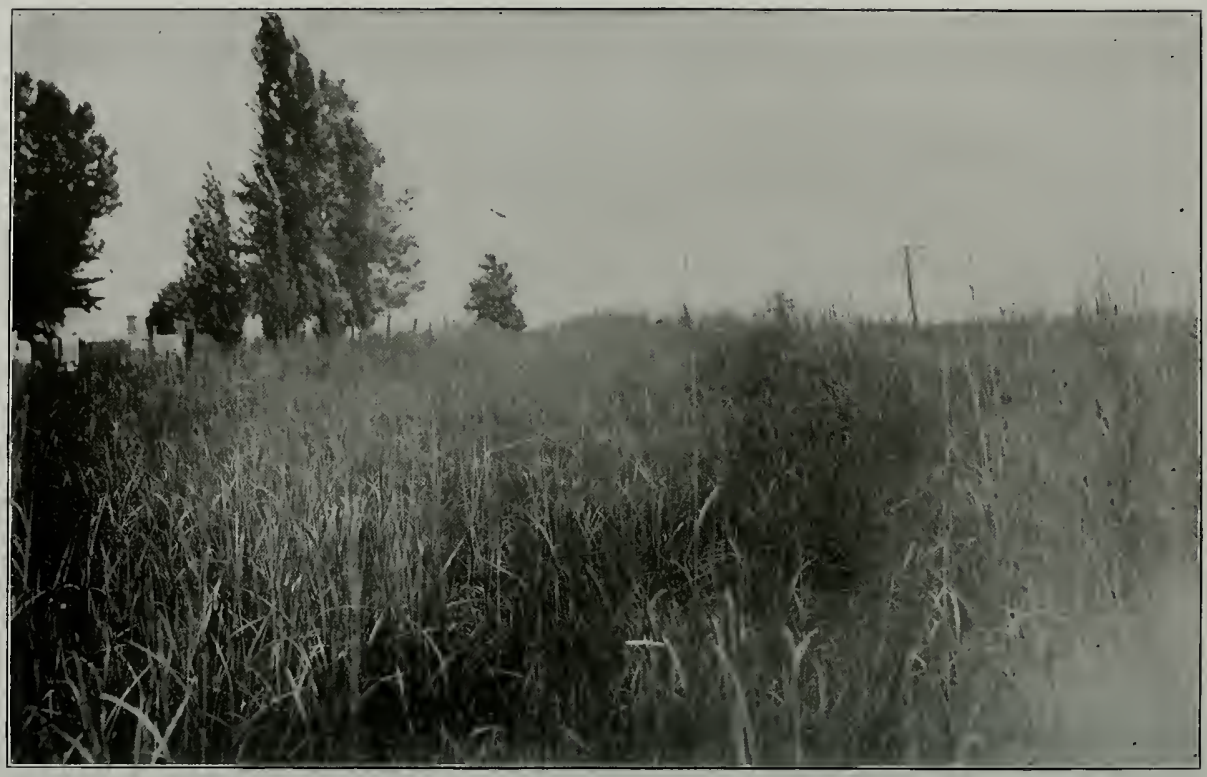

至

Andropogon fureatus on a railway right-of-way near Noble, Ill. 


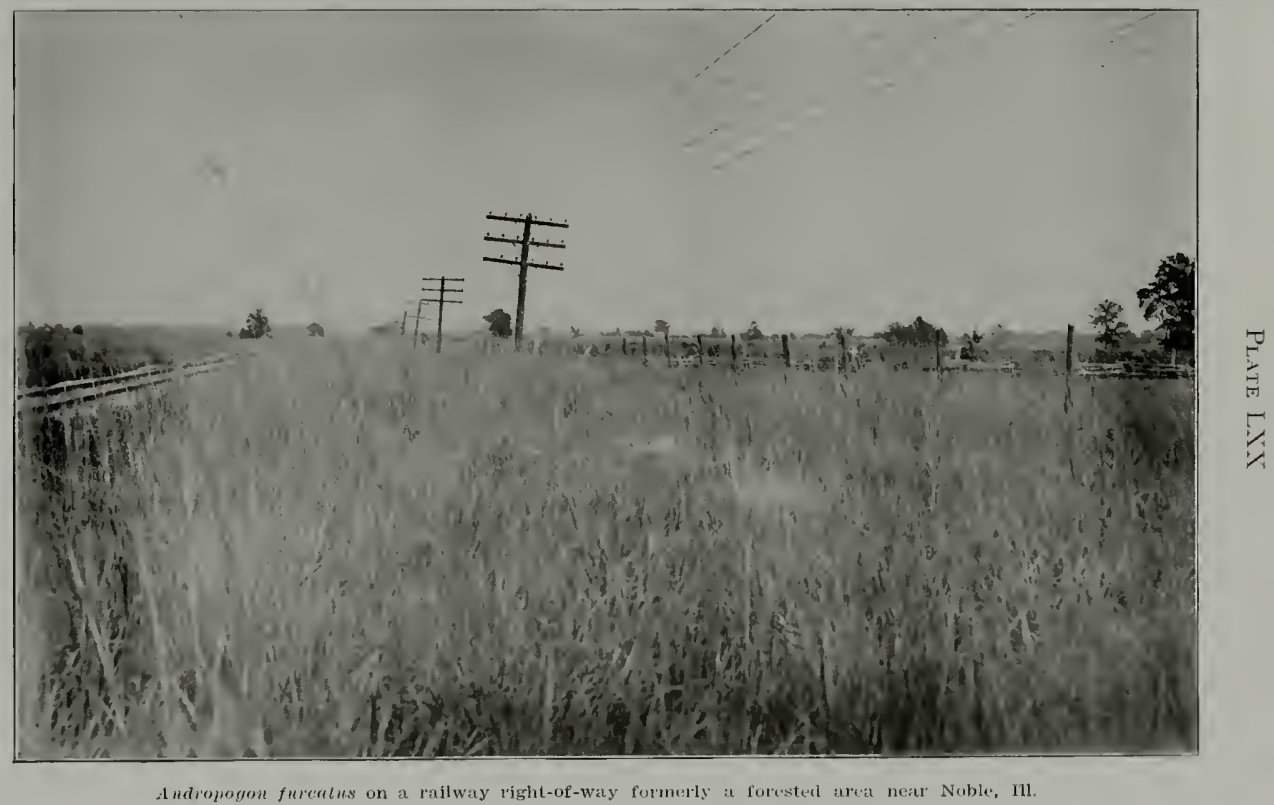




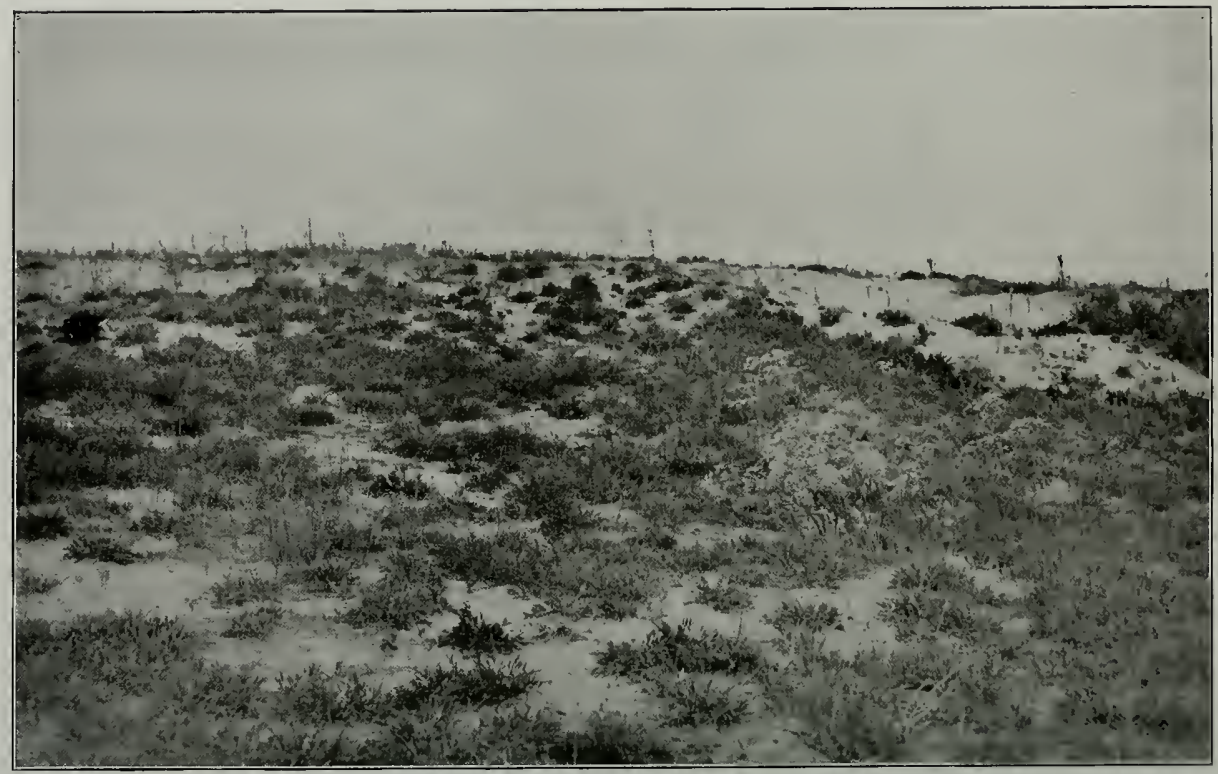

瓷

Panicum pseudopubescens association on sand, near Savanna, III. 



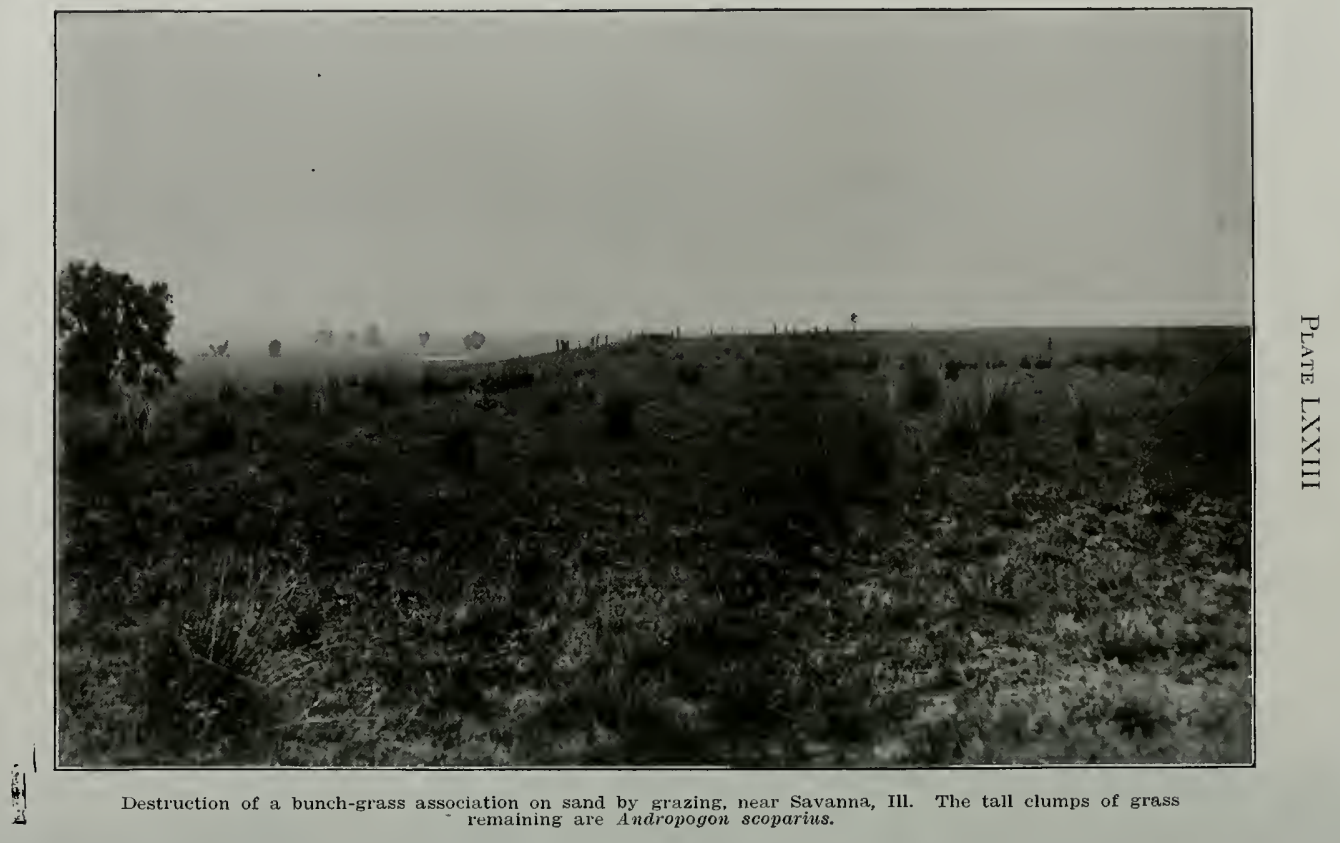




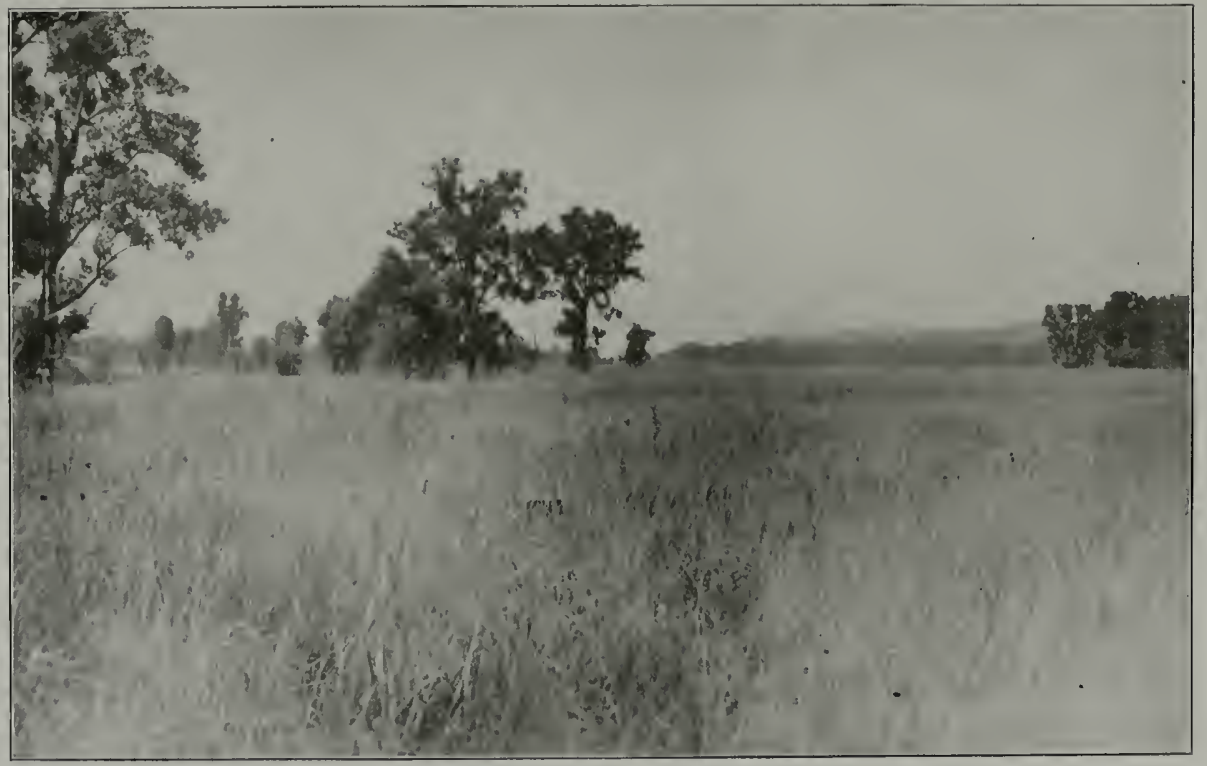

蒠

Audropogon scoprerins assoctation on a low sand hill south of Sitvanna, Ill 


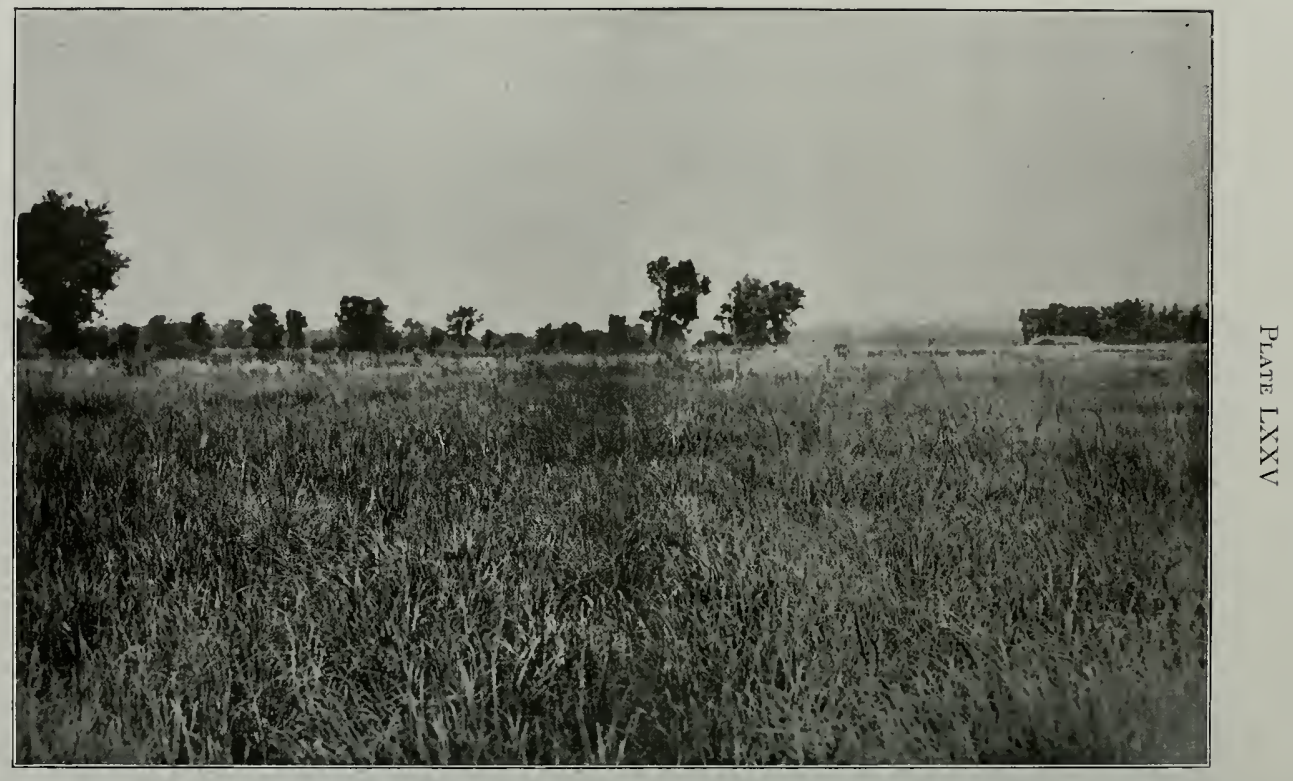

Andropogon fuccatus association on a low sand hill south of Savanna, Ill. The grass at this stage is more than three feet high, and the secondary species occupy but a very small part of the association. 


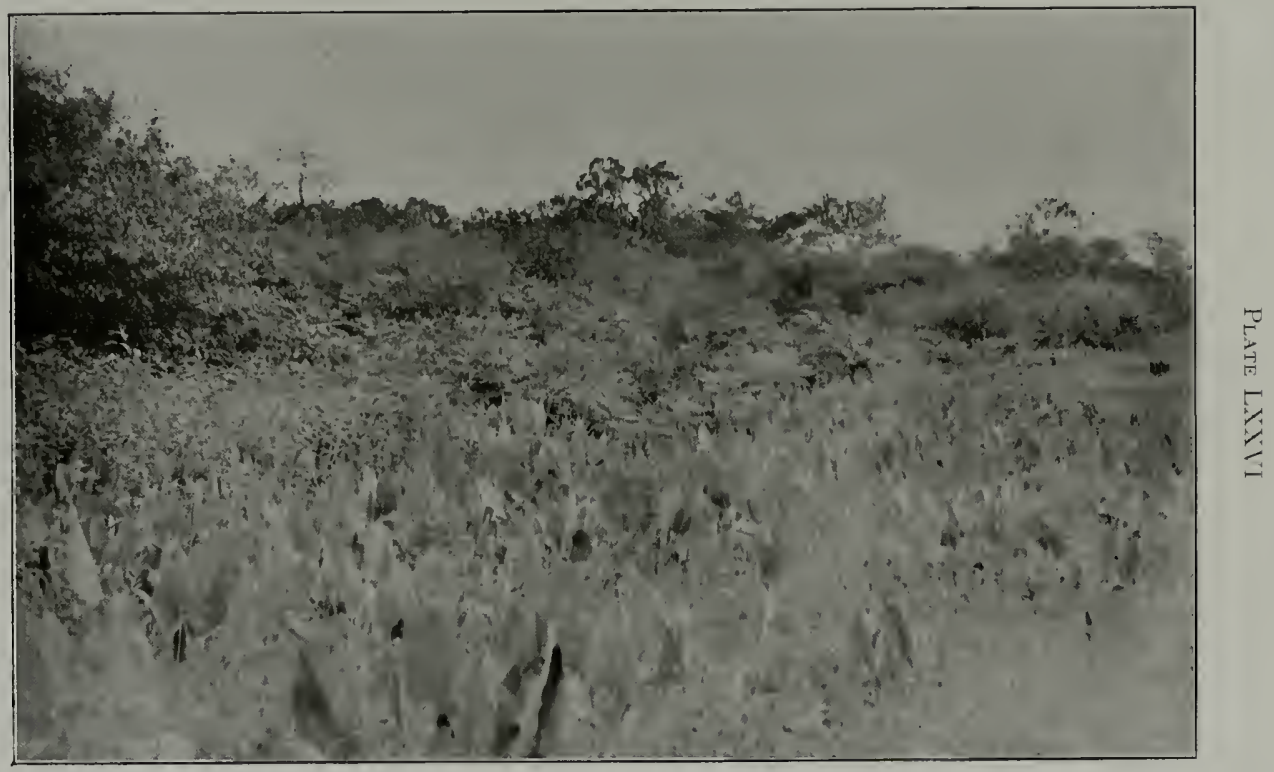

Rhus glabra, Pyrus coronaria, and Crataegus encroaching upon a prairie near Riverside, Ill. 


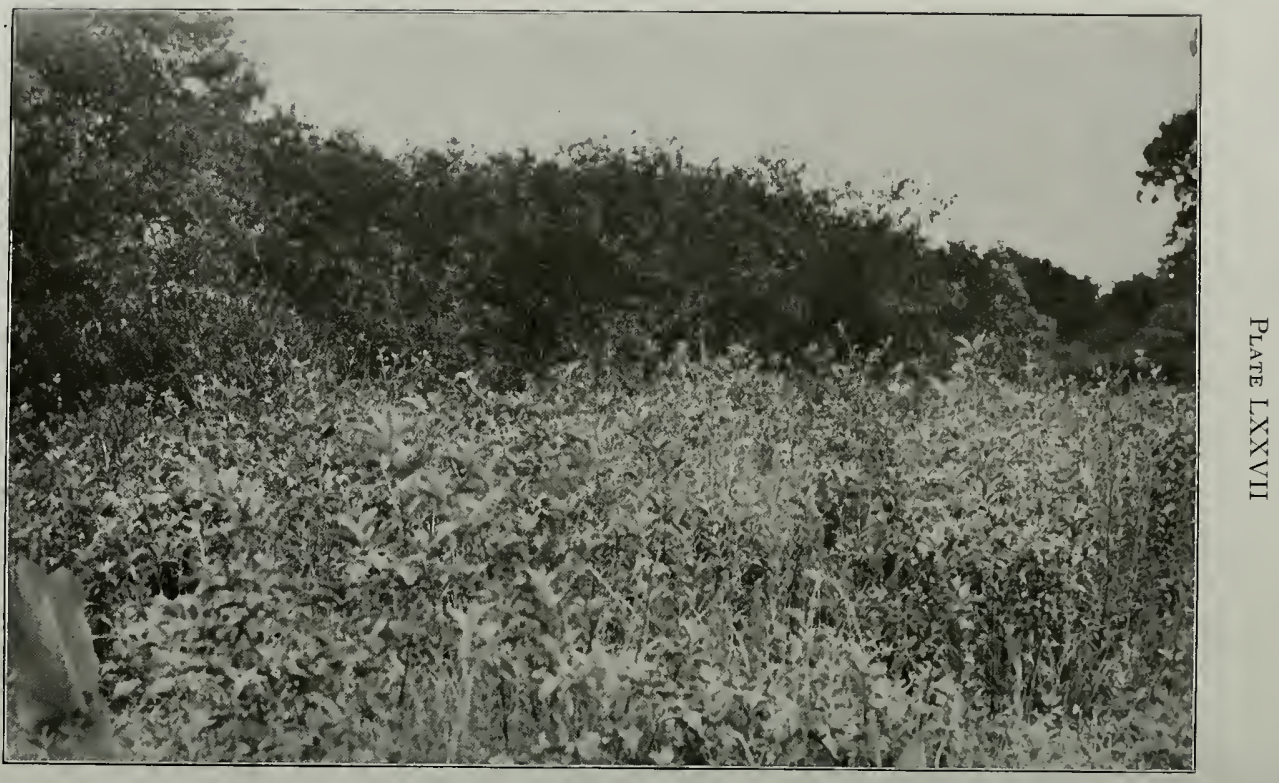

Prunus virginiana, Pyrus coronaria, and Crataegus encroaching upon a prairie near Riverside, Ill. 